\title{
HOW TO ATTRACT THE BIRDS
}

NELTJE BLANCHAN 


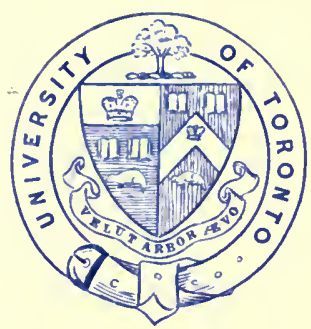

Dresentes to

\section{The Tibrary}

of the

\section{University of Toronto}

by

Executors of $\mathrm{Mrs}$. Hume Blake 
25

troceis selat tom nathes

Henas 1902 

Digitized by the Internet Archive in 2007 with funding from Microsoft Corporation 



\section{HOW TO ATTRACT THE BIRDS}






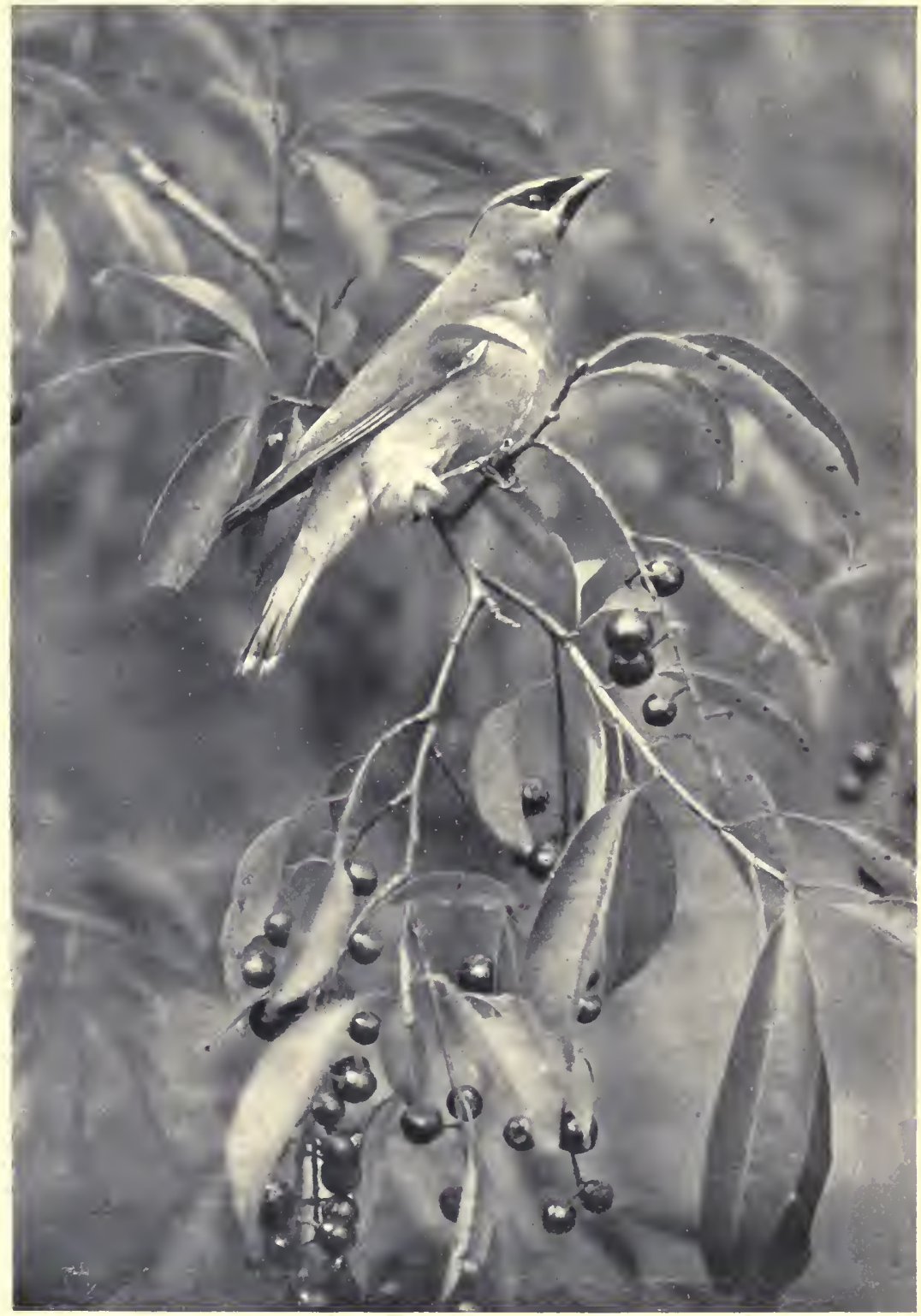

A cedar wax-wing in a choke-cherry tree. (Chapter 3)

Frontispiece 
$Z A v$

$B$

HOW TO ATTRACT THE BIRDS AND OTHER TALKS ABOUT BIRD NEIGHBOURS

$B Y$

NELTJE BLANCHAN (pseva.)

Author of "Bird Neighbours," "Birds that Hunt and Are Hunted" and "Nature's Garden"

488893

1.4 .49

TORONTO

THE COPP CLARK COMPANY, Linited

I 902 
COPYRIGHT, 1902

BY DOUBLEDAY, PAGE \& COMPANY

Published October, 1902

Mount pleagant pregs J. HORACE MCFARLAND COMPANY HAR RISBURG - PENNSYLVANIA 


\section{TABLE OF CONTENTS}

Chapter

J. How to Invite Bird Neighbours . . . . i I

II. The Ruby-Throat's Caterers . . . . . I9

III. Bird Architecture . . . . . . . . 37

IV. Hone Life . . . . . . . . . . 65

V. Nature's First LaW . . . . . . . . 9I

VI. Songs Without Word . . . . . . . II3

VII. Why Birds Conie and Go . . . . . . I4I

VIII. What BIRDS Do For Us . . . . . . ${ }^{6} 63$

IX. Some Naturalized Foreigners . . . . . 205 $\operatorname{INDEX} \cdot \quad \cdot \quad \cdot \quad \cdot \quad \cdot \quad \cdot \quad \cdot \quad \cdot 22 \mathrm{I}$ 

HOW TO INVITE BIRD NEIGHBOURS 



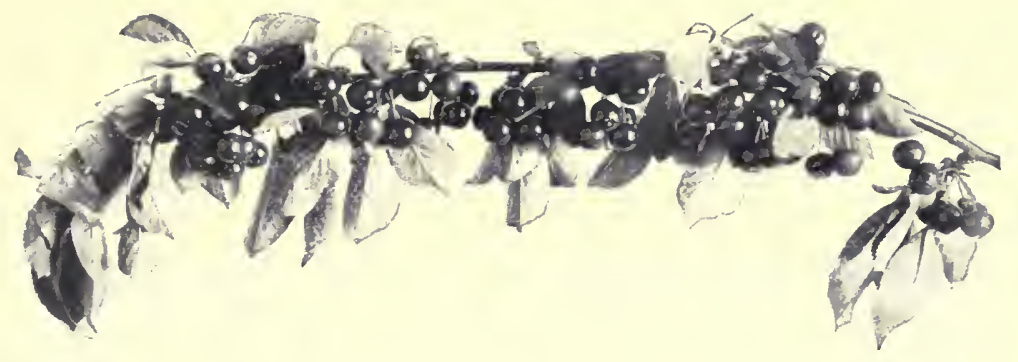

\section{HOW TO}

\section{ATTRACT THE BIRDS}

\section{CHAPTER I}

HOW TO INVITE BIRD NEIGHBOURS

ThE birds' point of view differs scarcely at all from our own in the essentials in life: Protection from enemies, the preservation of the family, a sheltered home, congenial environment, abundant food, and pure water-these natural rights the birds, like men, are ever seeking.

Each spring day bringing as it does hosts of feathered travellers from the Tropics and the Southern States where they have passed the winter, how can we induce some of them to pause on the journey long enough to investigate our garden attractions and happily to become our neighbours for the summer? Some birds there are-the wild ducks and hawks, for example_- that no amount of coaxing would induce to confide in man-the worst enemy or the best friend every creature has. But very many of the smaller birds, relying more on the 
How to Attract the Birds

safety and abundance of food near human settlements than on the more doubtful protection that deep remote forests afford, need little persuasion to

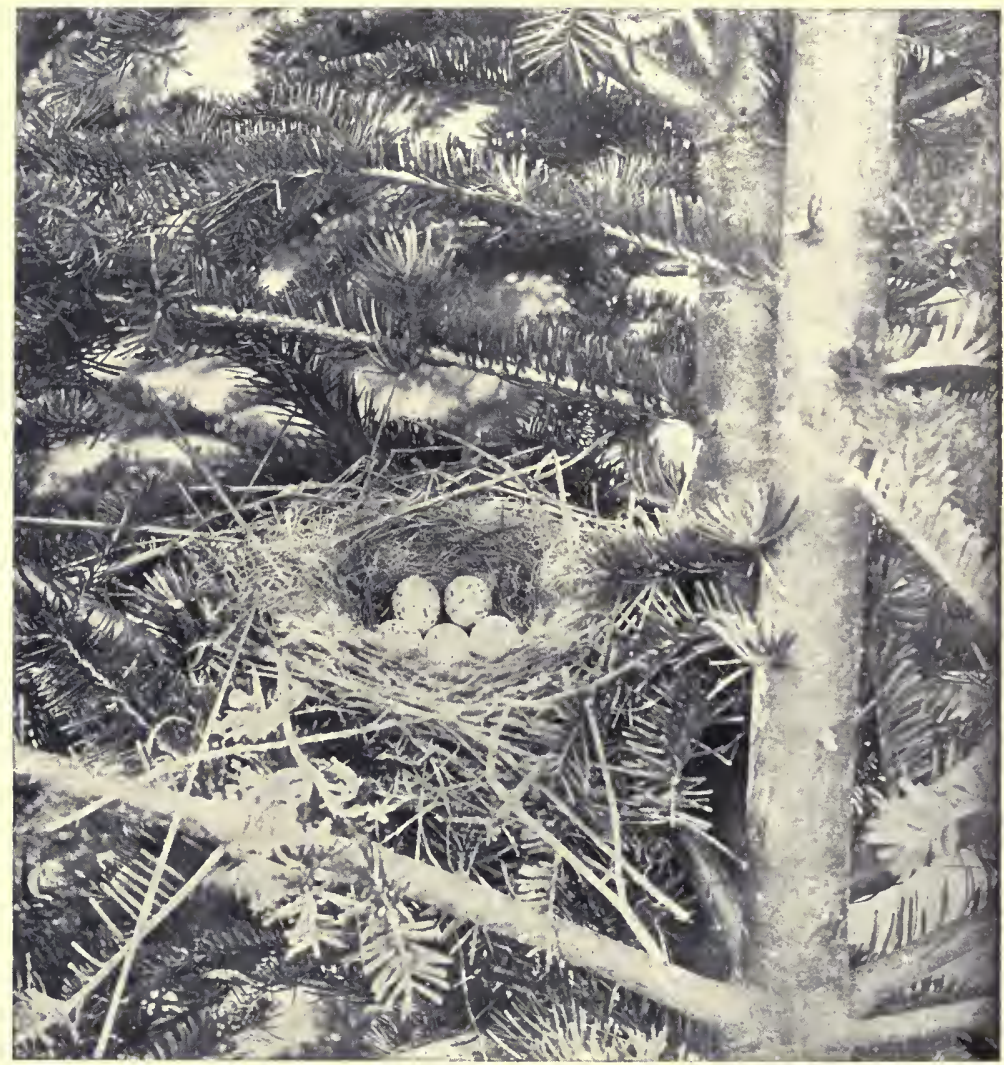

Photograph by Brounel

Cedar wax-wings postpone nesting till midsummer

remain. John Burroughs was not the only one to feel disappointed at the scarcity of birds about an Adirondack Camp as compared with his village home. 


\section{How to Invite Bird Neighbours}

\section{A BIRD'S-EYE VIEW OF OUR GARDENS}

If we realized how carefully and how hopefully our gardens and orchards are scrutinized every spring, and on what details judgment upon them is passed by the sharp-eyed inspectors, we might, so easily, with a little forethought, arrange them to the taste of the home seekers. Even in trolley nettled suburbs and in very small door-yards it is possible to make some birds, at least, feel conscious of their welcome. Large estates can be converted into great natural aviaries at one-tenth the cost of a hothouse. Cost, did I say? Why, one pair of chickadees in an orchard will destroy more insect eggs than the most expensive spraying machine.

It takes birds a surprisingly short time to resort where no gunning is allowed and very quickly, too, they learn where to avoid the silent deadly air-rifles and sling-shots of small boys; where prowling cats are permitted to lurk in ambush, and red squirrels, field mice and snakes play the role of villain in the tragedies of the nests. At the outset, every family must choose between a cat and the wild birds as pets; only heart-breaks result from the cruel combination.

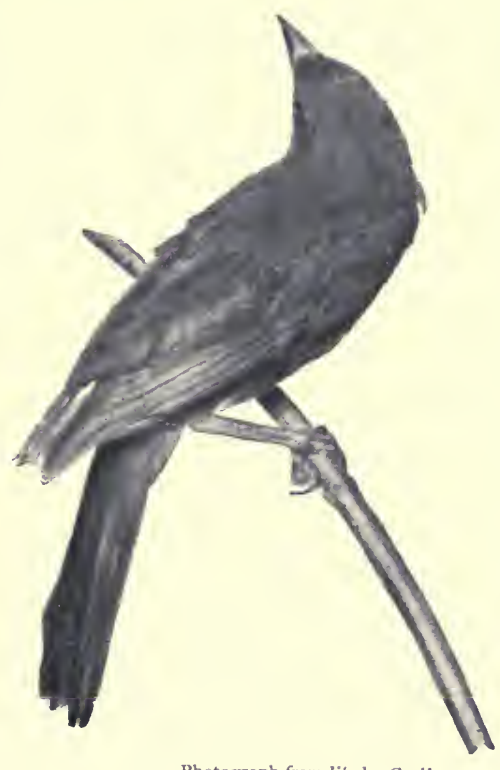

Photograph from life by Carlin An early nest-builder; the bronzed grackle 


\section{How to Attract the Birds}

\section{HOUSE HUNTING}

When a young man's fancy lightly turns to thoughts of love, mating is the birds' one absorbing idea. Some of them, having taken partners for life in previous years, or having found mates on the

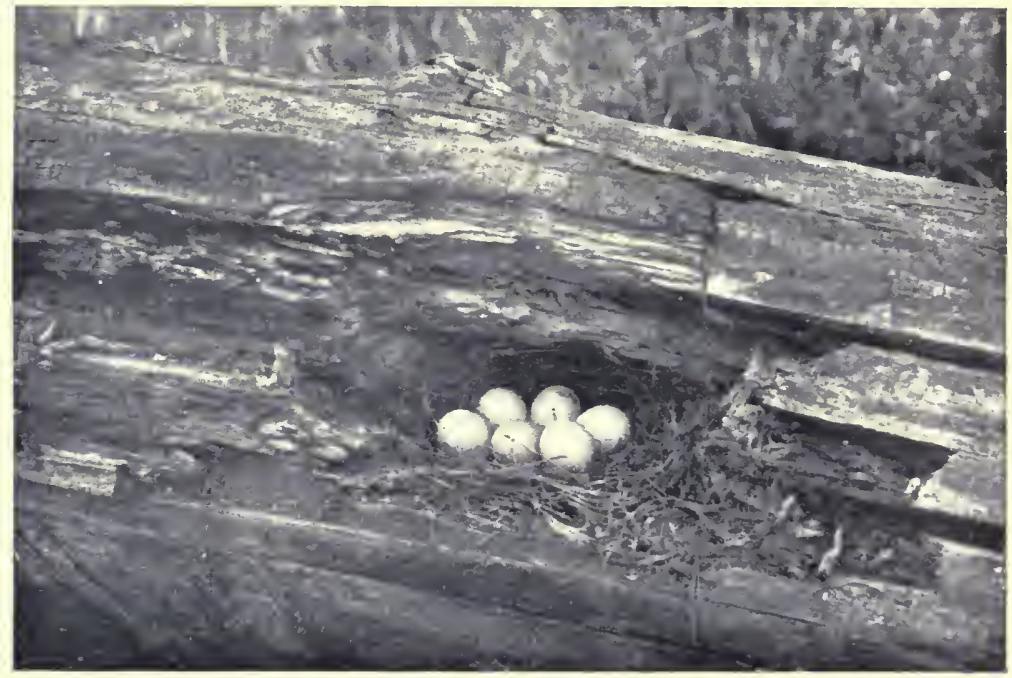

Photograph by Carlin

Blue-birds are peering about for some hole in an old hollow tree or fence

journey northward, are ready to begin housekeeping as soon as they reach our home grounds. Others, though still in the agonies of jealousy or the bliss of wooing, do not long delay the serious work of life. Only the cedar waxwings and goldfinch postpone nesting until midsummer, when their principal food supplies-choke-cherries and thistle seeds - are most abundant. But even in March, bluebirds are peering about for some hole in an oid hollow tree or fence rail to shelter their nest from 


\section{How to Invite Bird Neighbours}

rude spring winds. Flocks of iridescent grackles or blackbirds, as they are also called, wheeze and creak their discussions over suitable sites in the top of our tall evergreens. The robins' clear, ringing, military call is heard again from the apple trees and lawn. Dusky little phœbes timidly investigate the beams under our piazza roofs; swallows skim above our barns. A little later come Jenny Wren and Sir Christopher to dispute with the ubiquitous sparrow the right of possession to every sheltered cranny : the shutters of our houses, overhanging eaves, bird boxes and

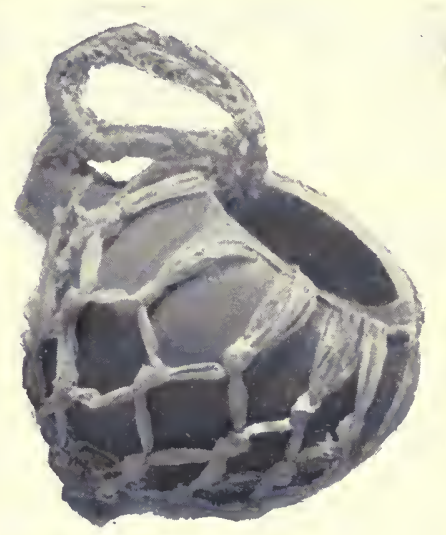
tree hollows. With a temper out of all proportion to its diminutive size, the house wren dashes at any intruder near the chosen home, chattering scoldings into his very ears until even the sparrow is glad to leave the place. Then how quickly bubbles up the rollicking song of ecstatic joy from the tiny victor's throat! In a free fight the bluebird, too, whose disposition is by no means so heavenly as his feathers, worsts the sparrow. Robins pay no more attention to the teasing impudence of that dingy little upstart than a St. Bernard pays to the yelps of small curs. 


\section{How to Attract the Birds}

\section{THE SPARROW QUESTION}

Indeed, a great deal of nonsense is talked about sparrows driving away other birds. Like the downtrodden Italian and other peasants from the Old World, the sparrows are

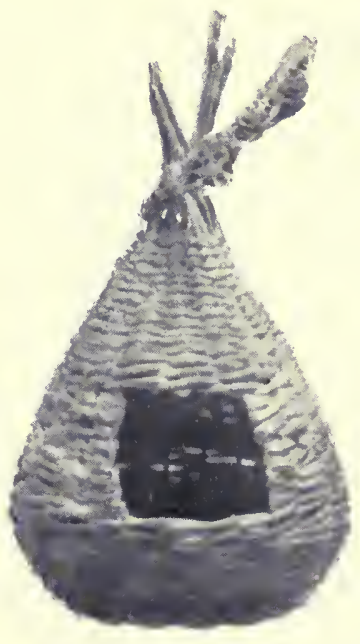

A basket house prepared to live here where others would starve. They kill no birds. We are too wont to attribute the results of our own misdeeds or shortcomings_the barbarities of millinery fashions, wanton slaughter masquerading as sport, the lack of good bird laws and the enforcing of them, where such exist-upon these troublesome, noisy, quarrelsome little feathered gamins. Fitted to survive after centuries of competitive struggle, they cannot be exterminated. As well try to eliminate that other triumphant European immigrant, the daisy, from our fields. Just as the introduction of the honey bee from Europe must cause our native flowers and insects to undergo certain changes of structure and habit, so the introduction of the English sparrow means change, adaptation, to our native birds. In spite of the sparrows, there is already noticeable a 


\section{How to Invite Bird Neighbours}

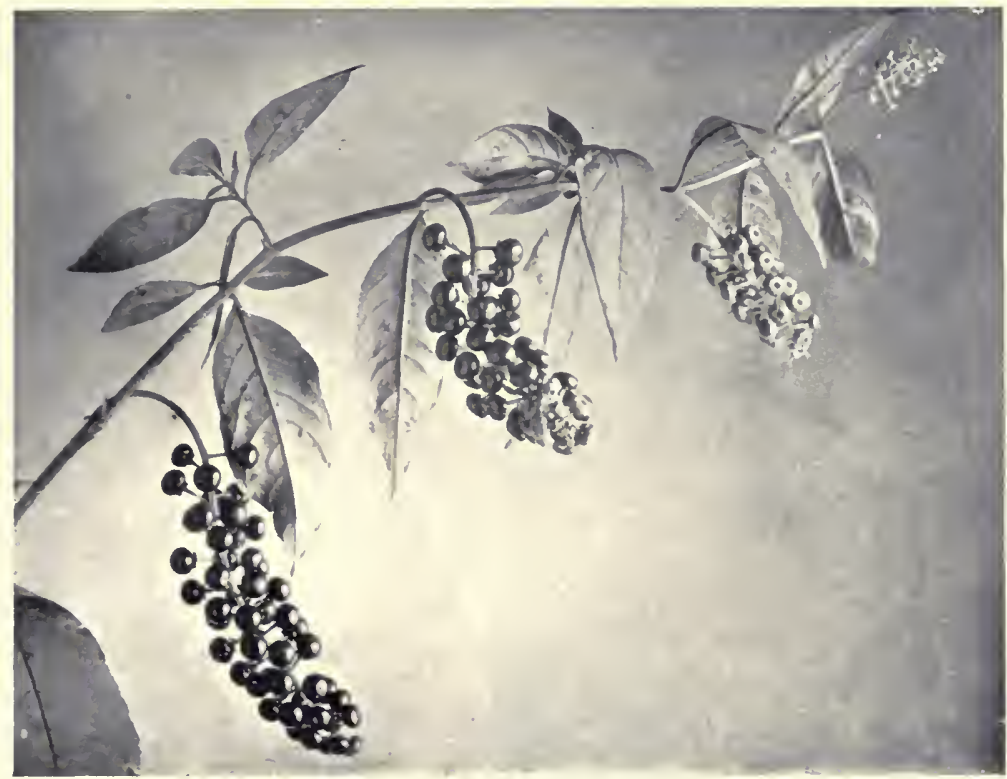

Poke-weed berries

Photograph by Brownell

large increase in the number of song birds wherever protective laws, reinforced by Audubon Societies and public sentiment, have operated for even a few years. Sparrows drive no birds from England.

\section{A'T'TRACTIVE TREES, SHRUBS AND VINES}

Protection and home being assured, the food supply becomes a burning question by June when, in well-regulated bird homes, there are little, gaping, clamouring mouths thrust above the nest every few minutes throughout the long day. In planting our gardens and lawns, why not remember the needs of the birds, if we really wish them about?

That birds love trees, large old ones and plenty of them, groves of mixed species, rather than a single 


\section{How to Attract the Birds}

kind, underbrush, shrubbery and tangled vines to hide and hunt among, no one need be told; but certain trees and bushes attract certain birds more than others. Some trees there are-the cotton-

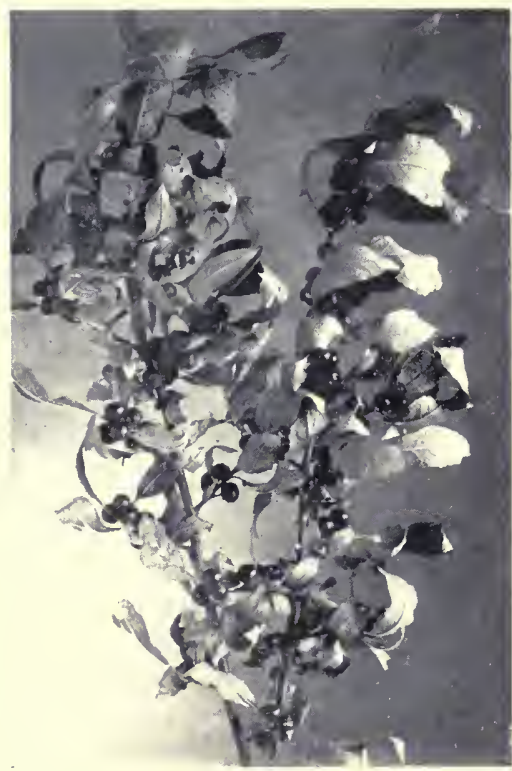

Photograph by Brownell

Berries of the American holly wood for examplewhich, from the bird's standpoint, are useful merely as perches, but others furnish food, too, or favourite nesting sites, therefore, why not choose them? If the bird-lover's door-yard is so small as to hold only one tree, no other one will attract so many feathered visitors as the Russian mulberry. Robins, catbirds, tanagers, grosbeaks, waxwings, orioles and thrushes are not by any means the only appreciative visitors with the poor sense to prefer the insipid, sweet fruit, to the best berry God ever made. Scientific farmers are now systematically planting mulberry trees, the shad bush and June berry as counter attractions to their strawberry beds, whose fruit ripens at the same time. Myriads of flies, ants, wasps and other insects that come to sip the syrup of over-ripe mulberries, draw insectivorous birds, as well as more dainty feasters.

Probably the next best food tree for birds is the 


\section{How to Invite Bird Neighbours}

choke cherry, whose racemes of small black fruit ripen from July to September. Here congregate large flocks of crested cedar wax-wings, more properly called cherry birds one thinks when the distended gullets of these sociable gourmands are observed through the opera glass. The Hickers, which seek the tree at dawn, robins and cuckoos, leave few cherries for hungry migrants on their way southward in autumn. There is always a quid pro quo in nature. Of course the birds are not the recipients of purely disinterested favours. By dropping undigested seeds far and wide, and so starting new colonies of plants, they repay their hosts for every favour received.

Tree and bush dogwoods, mountain ash, spruces, pines, juniper, hawthorn, viburnum, elder, black alder, wild plums, blackberries, cherries, crab apples, currants, raspberries, grapes and gooseberries, catbrier, burning bush, moonseed, wild yam, buckthorn, s u m a c h, holly, bittersweet, wild rose, wintergreen, partridge vine, hackberry,

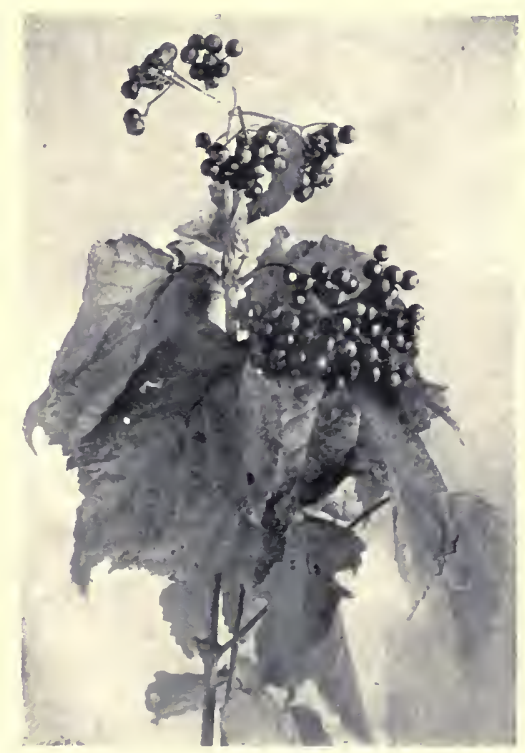

Photograph by 3rownell

Arrow-wood berries (October) snowberry, kinnikinic, auralia, honeysuckle bushes and twiners, mock orange, hop vine, huckleberries, Virginia creeper, clematis, bayberries, shad-bush-these 


\section{How to Attract the Birds}

are among the many wild and cultivated trees, shrubs and vines, whose fruit attracts the birds. Some berries and seeds ripen early in summer, some in autumn, others through the winter and last until the migrants of the following spring

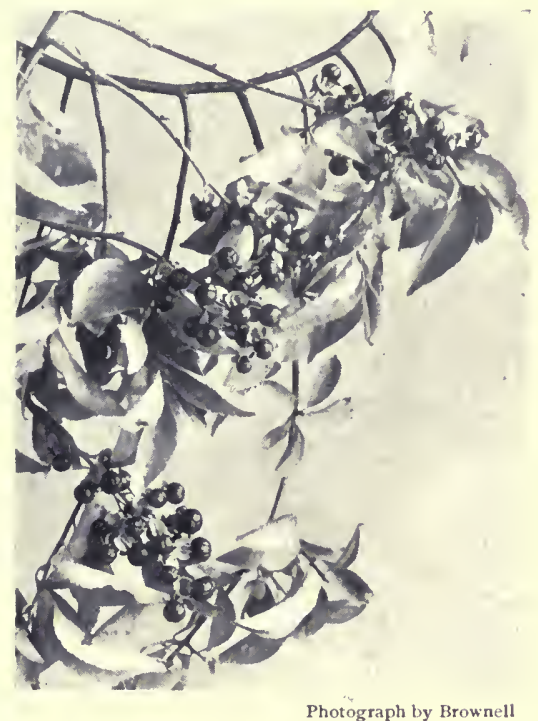

Bittersweet berries that furnish fall provender for the birds eagerly bolt them on their way North.

In the flower garden many seeds are pecked at, but the sunflowers', which give all the finch tribe a rich feast, are prime favourites. Goldfinches, however, apparently prefer the blue corn-flowers or ragged sailors, which should be sown in a corner of the wild garden if not for their beauty's sake then certainly for their seeds.

That jewelled atom, the ruby-throated humming bird, delights in so many flowers and plays so important a part in their cross-fertilization that he requires a separate chapter.

Birds can endure intense cold on full stomachs, but their winter larder must often be very lean. Never is hospitality so keenly appreciated as then; never are birds so welcome to us. Trimmings of beefsteak, lumps of suet and a rind of pork tied on the branches of trees near enough to the home to be watched by its inmates, attract some very inter- 


\section{How to Invite Bird Neighbours}

esting winter neighbours: chickadees, nuthatches, tufted titmice, brown creepers, woodpeckers and blue jays. Minced raw meat, waste canary, hemp and sunflower seed, buckwheat, cracked oats and corn, crumbs and the sweepings from the hay loft, scattered over the ground, make a delectable hash for feathered boarders with varied appetites. Food that can be put in dishes on piazza roofs or on shelves in trees either winter or summer for such soft-billed birds as robins, catbirds, mocking birds, thrushes and orioles - the most delightful and tuneful of bird neighbours - is made of equal parts of cornmeal, pea-meal and German moss into which enough molasses a n d melted suet or lard have been stirred to make a thick batter. If this mixture is fried for half an hour, it can be packed away in jars and will keep for weeks. Grated carrot or minced apple is a welcome addition.

Last autumn, when a New York family was seated around the breakfast table, a young woodthrush flew into the dining-room through

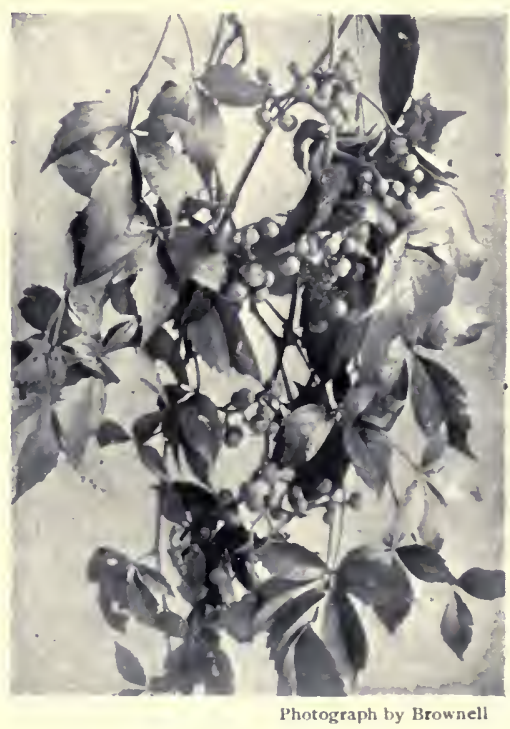

Berries of the Virginia creeper the open window. It was a straggler from a flock on its way South. Weary, hungry and faint with travel, it alighted on the frame of a picture which, 
How to Attract the Birds

by a strange and beautiful coincidence, was one of Audubon's old prints. Some branches of bright

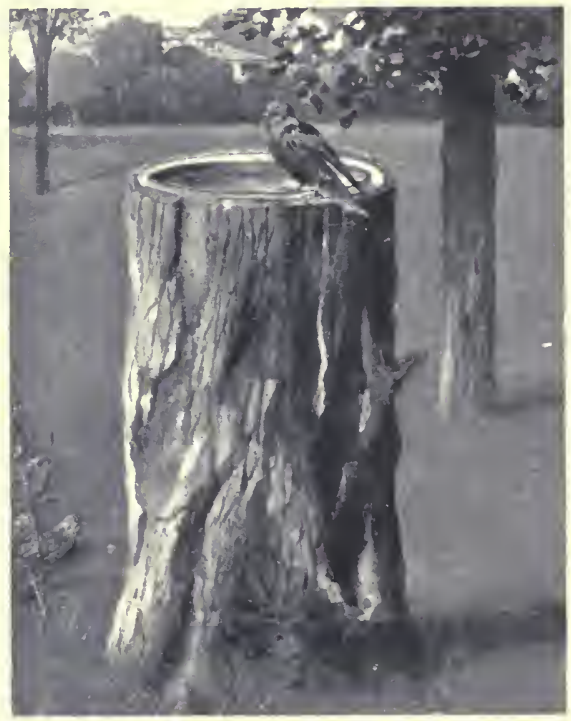

A combination bath tub and drinking pan alder berries happily stood in a vase on the mantel below. Fear was instantly forgotten in the joy of feasting. A f ter a hearty meal of the familiar fruit, a n d de e p draughts of water from a cup placed near the berries, the thrush departed as it came, but refreshed for its travels. If this denizen of the woods could forget its natural shyness under such unnatural conditions, how much more readily will invitations to feast be accepted al fresco?

\section{THE MOST INTERESTING SPOT ON YOUR GROUNDS}

In regions where there are no brooks or lakes, birds must sometimes fly many miles for a drink. Perhaps more young birds die for lack of water than from any other cause. Not even a mulberry tree attracts so many visitors as a bath tub, which also serves them as a drinking pan, for they are not squeamish! 


\section{How to Invite Bird Neighbours}

But see to it that the pan is raised above the reach of cats; only on large estates where none are kept is it safe to sink the pan into a lawn. Birds cannot fly far with wet feathers. They must first dry and preen them. For this reason, as well as for the cool shade they afford, trees and shrubbery should partially screen the drinking water. Where a small stream cannot trickle into a fountain, fresh water poured in a pan daily, or even twice a day at midsummer, is very gratefully appreciated when many a rare, shy bird, its bill open and gasping from the heat, seeks refreshment. If the water be deep, the birds will let it alone through fear of drowning when they stand on the brim, and tip forward as they must for a draught. A pan sh allow enough for wading, or a deeper one supplied with stones for the drinkers to stand on safely, furnishes more interesting sights to a household and pure fun than any other object you can watch throughout a season. Children enjoy it keenly. Sixty-nine different

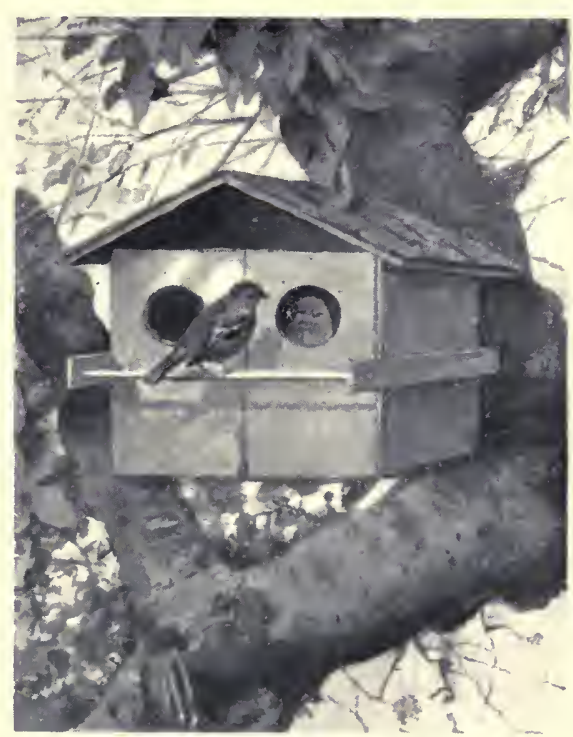

A bird home made from a wooden starch box species of birds, many rare warblers and migrants among them, came in one season to drink on a 


\section{How to Attract the Birds}

suburban lawn, although a tiny aggressive wren felt cocksure that he alone owned that basin.

\section{HOUSES TO LET}

In our over-conventional gardens hollow trees or one with so much as a partially decayed branch

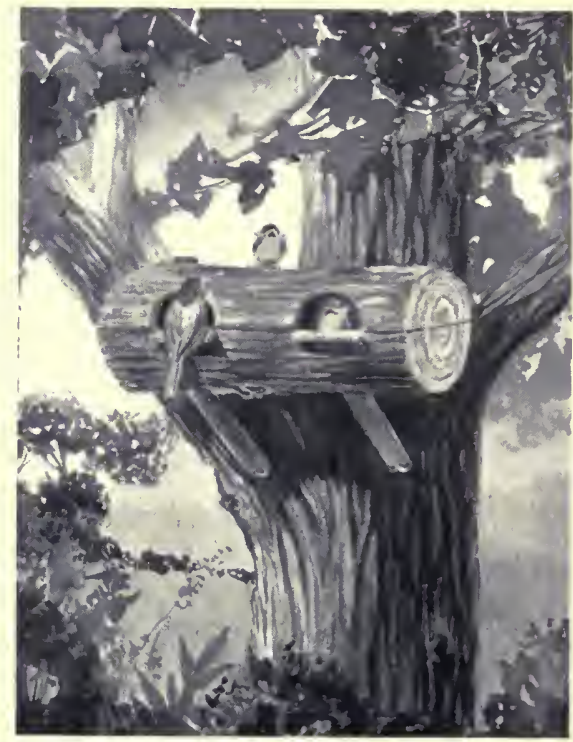

A simple type of bird box

such as the flicker, the sapsucker, the red-headed, downy and hairy woodpeckers, bluebirds, martins, wrens, chickadees, titmice, nuthatches, the smaller owls, crested flycatchers, and some other birds love to nest in, are cut down; but what substitutes for these natural shelters do we provide?

A short log sawed in two, the halves hollowed out in the centre and nailed together again with an 
How to Invite Bird Neighbours
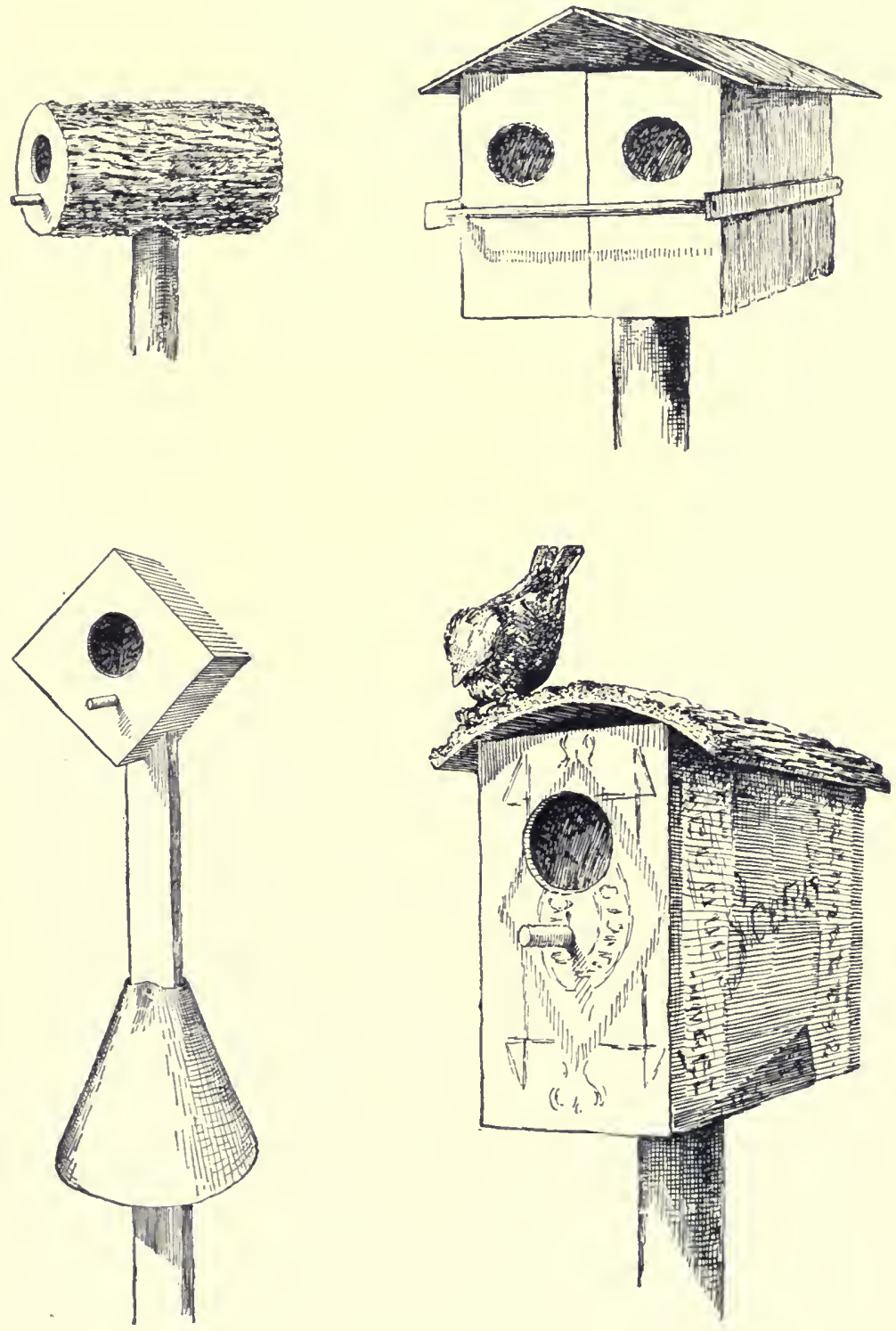

Bird houses that a child can make 
cntrance to the cavity on one side of the log, is a pattern that any village carpenter or schoolboy can adapt to the tiny wren and the large woodpecker. $1 \mathrm{~W}$ ooden starch boxes, provided with sloping roofs and covered with bits of bark, may be divided into two compartments with an entrance and perches at either end, although a one-room cabin is preferable, for birds love privacy at the nesting season, however large may be their flocks at other times. The tenement for twenty families is a modern city attainment for humans to which few birds aspire. Therefore, do not make many-roomed houses or put more than one $\log$ cabin, can, gourd or box in one tree. Lodgings should be in readiness very early in the spring, lest a pair of hopeful feathered house-hunters slip by, unable to find a home.

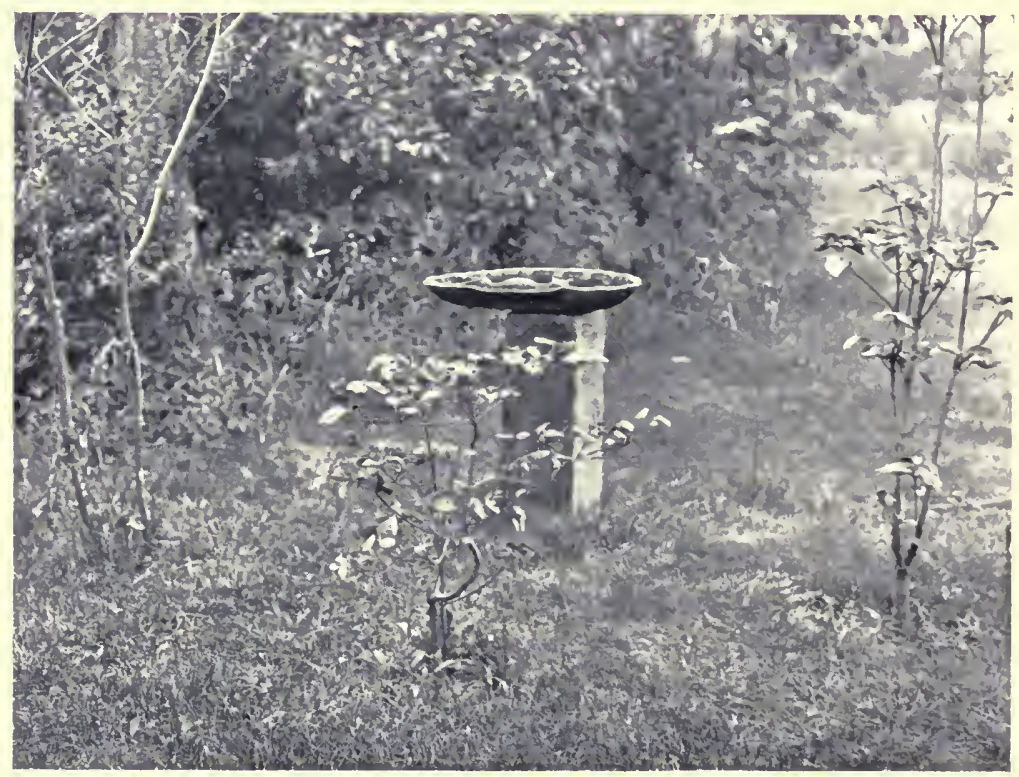

A drinking shell above the reach of cats 
THE RUBY-THROAT'S CATERERS 



\section{CHAPTER II \\ THE RUBY-THROAT'S CATERERS}

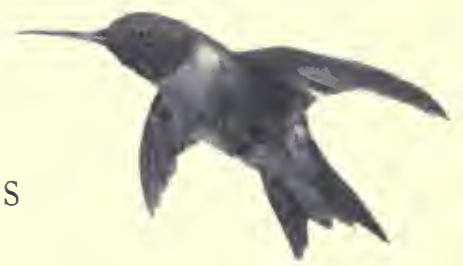

WHAT tempts the ruby-throated humming-bird to travel every spring from Central America as far north as the Arctic Circle, leaving behind him for a season those tropical delights so dear to four hundred or more stay-at-home relatives while he, the sole representative of this charming New World family found east of the Mississippi and north of Florida, spends half his life among us in voluntary exile? How it stirs the imagination to picture the solitary, tiny migrant, a mere atom of bird life, moving above the range of human sight through the vast dome of sky, "lone wandering but not lost"! Borne swiftly onward by rapidly vibrating wings that measure barely two inches in length, he covers the thousands of miles between his winter home and his summer one by easy stages and arrives at his chosen destination, weather permitting, at approximately the same date year after year. Why does he come North?

One of the enlarging ideas gained through the study of Nature is that the same primal motives govern the actions of plant, bird, beast and man alike,- that all sentient beings act intelligently 


\section{How to Attract the Birds}

through the same strong, animating desires, their powers differing only in degree, not in kind. Naturally, self-preservation and the favourable perpetuation of the species are fundamental.

In tropical America, where vegetation is prodigal of bloom and insect life fairly teems, the rubythroat finds himself among a host of rivals for every drop of nectar secreted in the flowers and for every minute insect his tongue craves. But the competition for food, however keen, is no stronger than every creature requires to keep its faculties thoroughly alive. Presently even the luxuriant tropical vegetation takes a rest; insect life becomes dormant; there is not food enough for all, and hunger, the sharpest of spurs, begins to prick. How did the ruby-throat learn of our summer at the North, and that by following the course of the sun he might live in perpetual abundance? Doubtless his ances-

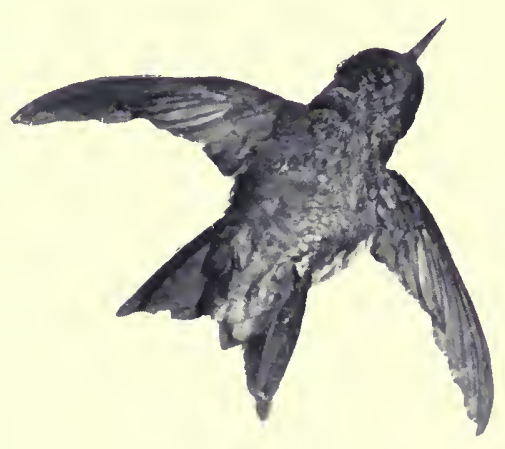

tors for ages back wandered farther and farther northward year by year in search of food, finding encouragement all the way; and through what scientists call the instinct of orientation, that is, the law of reversed direction, traced their way back to the tropics even from Labrador. Stirred by the same impulse, intelligent merchants, closely pressed by competition in the great centres of trade at home, migrate to China or the Philippines, where they may have the whole field to themselves. 


\section{The Ruby-throat's Caterers}

Before the coming of the Europeans to these shores with their imported trees, vines, shrubbery and flowering plants, what flowers in our area of Nature's garden undertook to feed the ruby-throat? It is true that almost any blossom which secretes nectar could be robbed by this little sprite. Nature always rewards the more highly developed of her struggling children by making the forms beneath them tributary to them. "All things are yours" was said to man alone. On such flowers as are easily drained by the mob of bees, wasps, moths and butterflies, the humming-bird wastes little time. Flowers like Jack-in-the-pulpit avowedly cater to gnats. Some, like the carrionscented trillium allure flesh flies. The iris, gentian and many another blue or purple flower charm the more highly specialized bees by wearing what Sir John Lubbock proved to be their favourite colour. Butterflies delight in bright pinks especially, although there are few exclusive butterfly flowers. The night-flying moths come to the wooing of the twining white honeysuckle, tobacco plant, lily, moon-flower, evening primrose and a host of other white or yellow charmers, easily seen in the gloaming when brighter hues have faded into the prevailing darkness, or detected from afar by their perfume. And so, if we could go through the entire list of flowers in our gardens and those growing wild, we should find that each is deliberately designed to 
attract, with special pleasing features, the insect or insects upon which it has become dependent for help in getting its pollen transferred from flower to flower. Self-pollination, we now clearly see, is one of the horrors of the vegetable kingdom; yet it was not until Darwin proved in countless experiments that cross-fertilization (pollen carried from one flower and placed upon the stigma of another) results in offspring which vanquish the offspring of self-fertilization in the struggle for existence, that the immense value of insect pollen carriers was understood. No wonder the flowers take infinite pains to entertain their insect benefactors and punish relentlessly the useless intruders!

But certain flowers, it has been noticed, do not attract insects; even the great bumble-bees, moths and butterflies, with very long tongues, cannot drain, by fair means, the columbine, for example. It is true that mischievous bees do occasionally bite holes through the tip of the columbine's horns of plenty, but it is evident that, since the flower receives no benefit from this rascally procedure, they cannot be legitimate guests. Large bumble-bees, however, doubtless pay their way. Flowers and insects form a mutual benefit co-operative association, in which there is not half so much pilfering done as in our business world. There must be quid pro quo or there is no trade in nature. Finally, it was learned that just as there are fly, bee, beetle, wasp, butterfly and moth flowers, so there are flowers which avowedly cater to the humming-bird. He is an exacting little guest, demanding much of his entertainer who would in turn be served by him. First of all, he likes to have a 


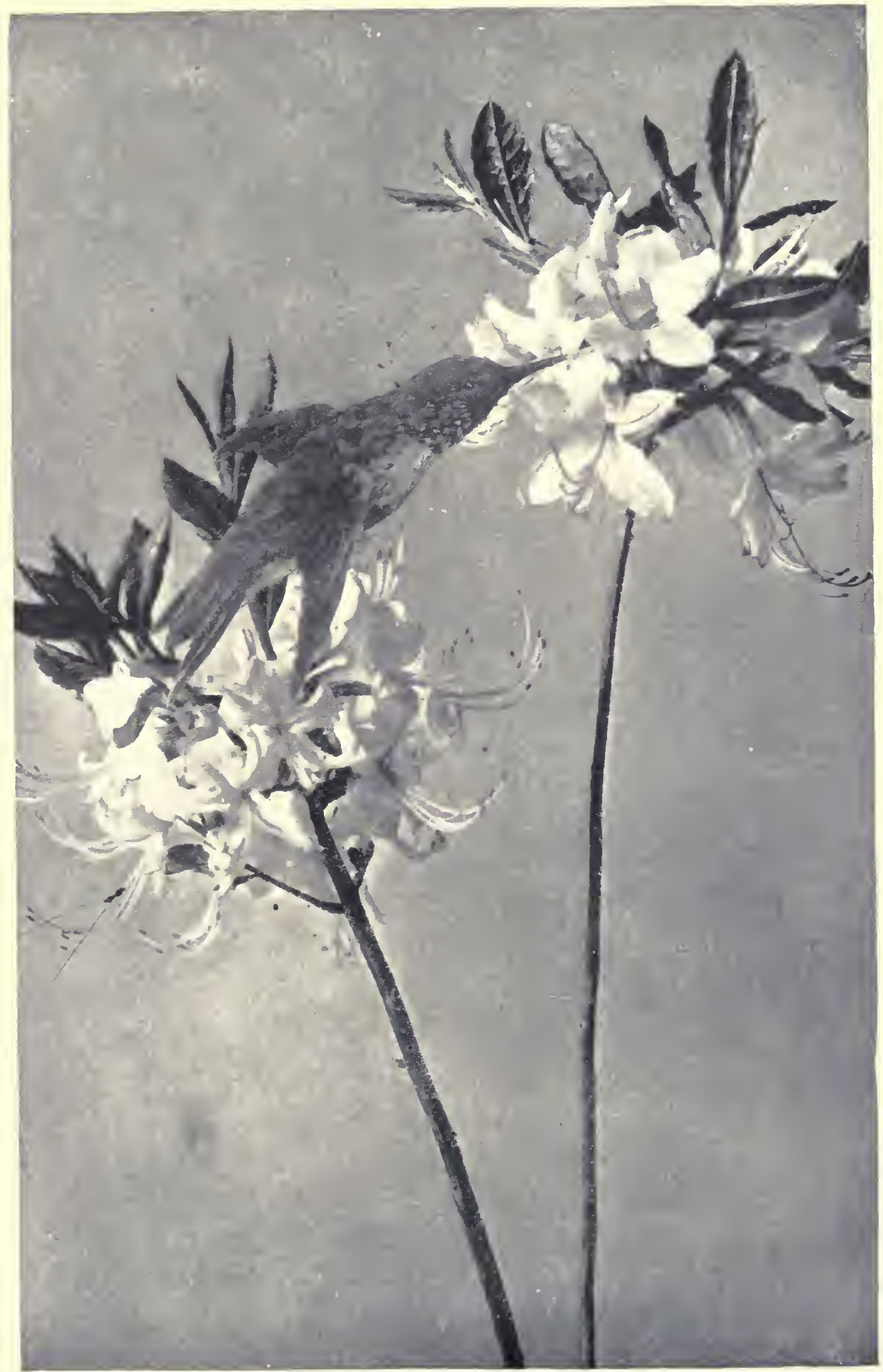

Trespassing on the butterfly's preserves 



\section{'The Ruby-throat's Caterers}

vivid advertisement to attract his eye when he is flashing about through the sunshine in search of food. Some one once asked Eugene Field what was his favourite colour. "Why, I like any colour at all, so long as it's red," he replied-an answer which the rubythroat made to the flowers ages ago. It will be noticed that the blossoms which the bird monopolizes are either red or orange: possibly the latter please him for the sake of the red that was mixed with the yellow when their corollas were painted. Such flowers as cater to insects must provide a landing place, a lip or flattened platform of some kind; but this the humming-bird, which sucks with his wings in motion, of course does not require. Nor does perfume appeal to him. Pathfinders to the nectary-little dark lines or patches of bright colour on the petals such as the bee likes to see on his flowers-the hummingbird may ignore. But he does demand that his red or orange flowers shall hide away their nectar in deep tubes, where the mob cannot drain them and where even his most threatening rivals, the larger bumblebees, moths and butterflies, will find it difficult to extract. From the tip of his needle-like bill his 


\section{How to Attract the Birds}

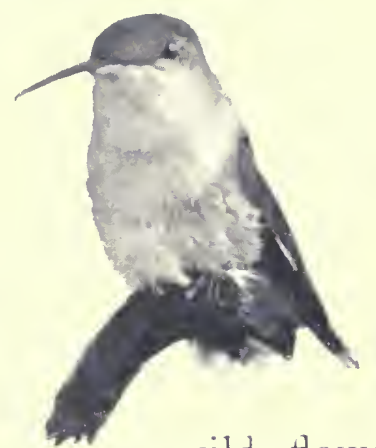

tongue can be run out at will and turned in any direction to lick up the last drop of sweets in a curved cornucopia, whereas both bee and butterfly must insert their tongues in a straight line. Here he has a great advantage over them.

Again, he stipulates that the wild thowers which cater to him here shall bloom so as to feed him in orderly succession while it suits his convenience to remain away from the tropics, not to gorge him at one time and starve him at another. His visit in the vicinity of New York lasts from May to October.

In the Southern States, through which he is passing in April, wooded hillsides and thickets are already gav with whorls of the coral honeysuckle's brilliant, slender, tubular flowers, flaunted from the tips of the branching vine where the dullest eye must be arrested by their beauty. Into these deep wells he plunges his bill and finds ample refreshment on his journey, especially when he adds to his menu some of the gauzywinged little insects which have taken shelter from the spring winds within the orange-lined red trumpets. By carrying the ripe pollen shed from the anthers of one flower to the stigma of another, the ruby-throat pays the only price asked for 


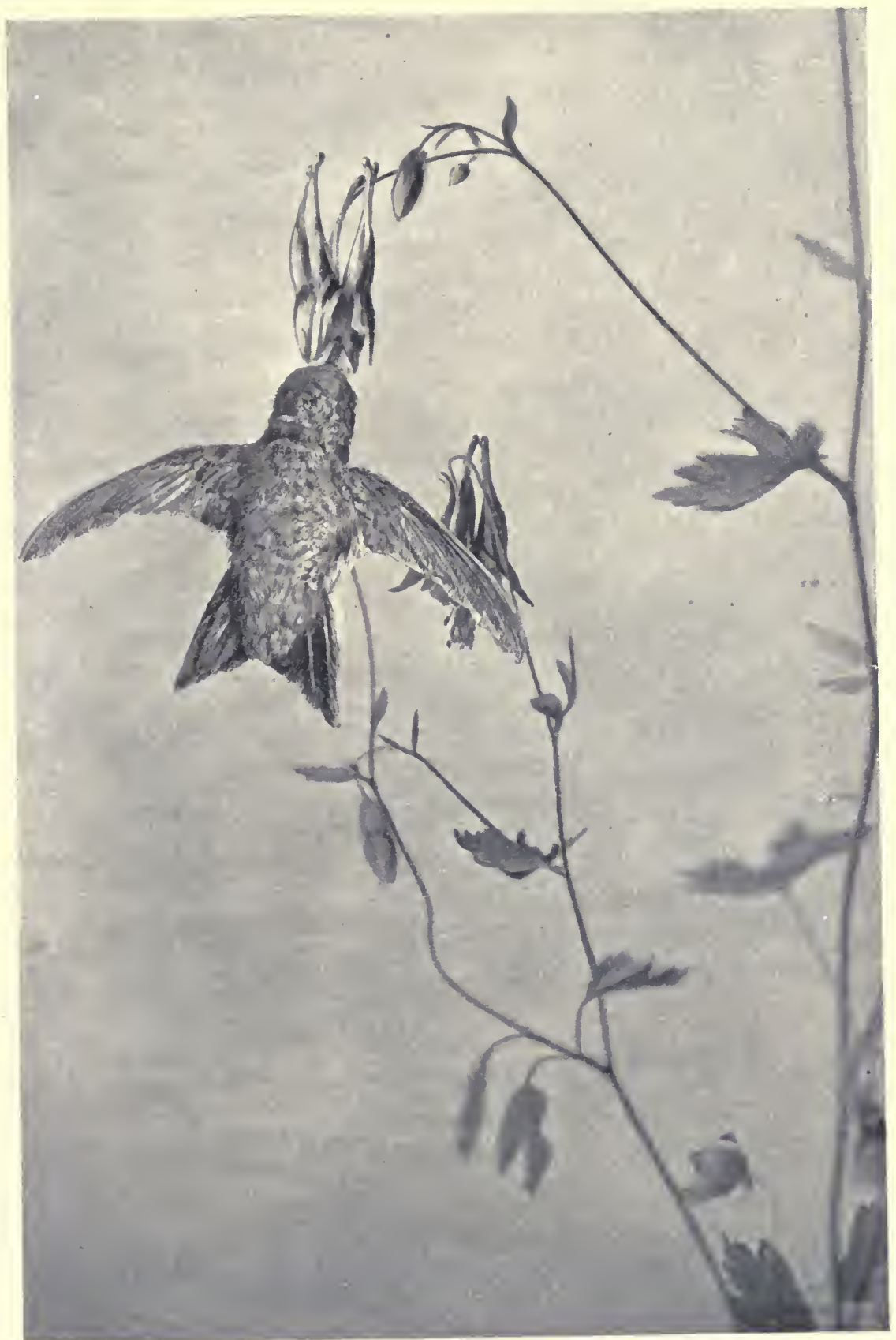

Draining the columbine's horns of plenty 



\section{The Ruby-throat's Caterers}

his generous entertainment. Late in the season other larger birds on their way southward will bolt the bright berries on this vine and distribute the seeds over a wide area. It would, perhaps, be impossible to find another plant more wholly dependent upon the ministration of birds than the coral honeysuckle. Small-flowered bush honeysuckles have adapted themselves to small bees; those with longer tubes and greater ambition strive to please bumble-bees; the twining honeysuckle seen on every village porch wooes the sphinx-moth with white, deliciously sweet flowers, most fragrant at evening and which turn yellow after fertilization. Quite frequently the larger sphin $x$-moths are mistaken for

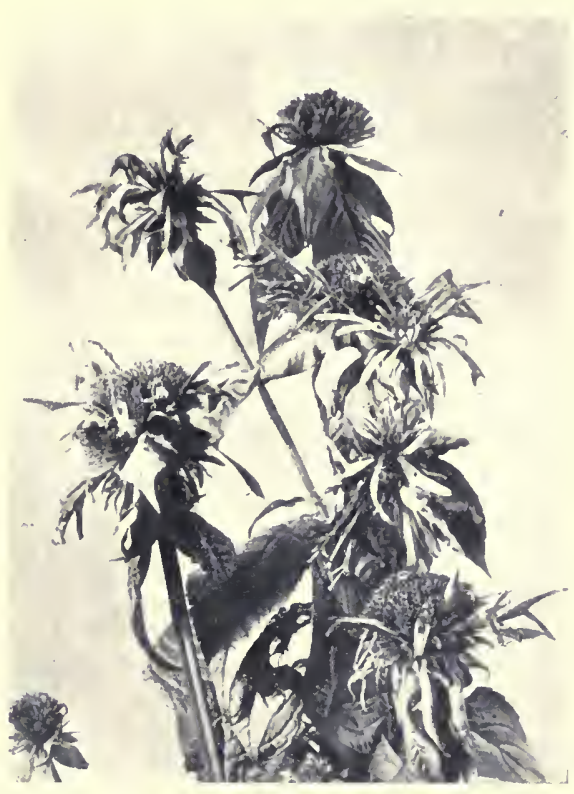

Oswego tea

humming-birds at gloaming when the former begin their rounds. It is true the ruby-throat often visits the moth's own flowers, but in the rubes of those which, like the twining honeysuckle, have newly opened at evening for their legitimate benefactors' benefit, the bird finds little left to reward his search the following day unless the previous evening has been too 


\section{How to Attract the Birds}

windy or rainy for the moths to Hy. The coral honeysuckle's nectar cannot easily be reached by bees; its trumpets could not be seen after dark by the moths; moreover, it has no fragrance to guide them, but it pleases the ruby-throat

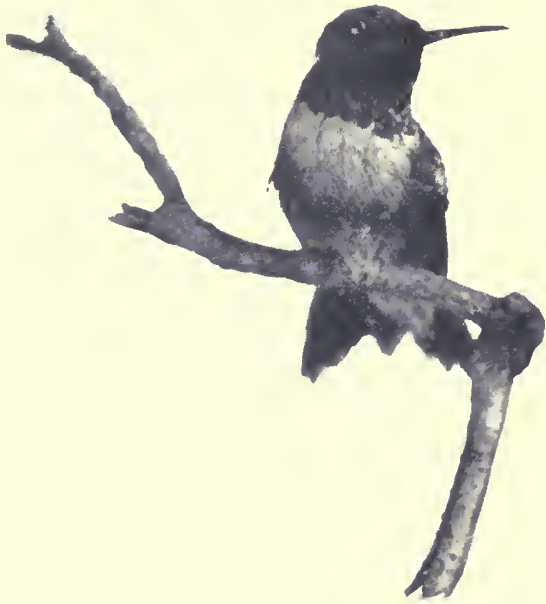
in every essential respect.

What is the next flower to spread his feast? With a broader and more northerly range than the coral honeysuckle's, the painted-cup or Indian paint-brush scatters its vivid scarlet tufts through the fresh green grass on meadow and prairie in May, its blooming season extending to July. Usually the first hummingbird of the season is seen suspended as if by magic over these glowing flakes of fire. In this species not the flowers themselves-for they are greenish yellowbut the floral bracts which enfold them are vermilion advertisements to catch the ruby-throat's eye. Other members of the figwort family, to which the painted-cup belongs, wear the bee's favourite colour and have provided a landing place on their lower lips for their benefactors; but here, what would be superfluous at the painted-cup's entrance, Nature has eliminated.

Closely following the painted-cup, and indeed partly overlapping its season, comes the graceful, swinging, rock-loving columbine. Inasmuch as both these flowers rarely grow in the same 


\section{The Ruby-throat's Caterers}

neighbourhood, and as increased numbers of rubythroat migrants need to be fed at their blooming season, there is ample opportunity for both rivals to flourish. In the swollen tips of each of the five inverted red and yellow horns of plenty which go to make up a columbine, nectar is secreted. Small bees with their short tongues may well abandon hope of reaching it. Owing to the position of the flower, butterflies, which would have to place themselves upside down, could scarcely hold by their weak legs while sucking, and their tongues flex readily only when directed downward toward their bodies. Large bumble-bees, to which the shorter spurred blue wild columbine of Europe is perfectly adapted, find our species so difficult to drain that, rather than attempt the task, they too often nip holes in the nectaries, just as they do in the larkspurs, Dutchman's breeches, squirrelcorn, but ter and eggs, jewel weed and other flowers which make dining too difficult for the clever rogues. But when the rubythroat whirrs up to the columbine,

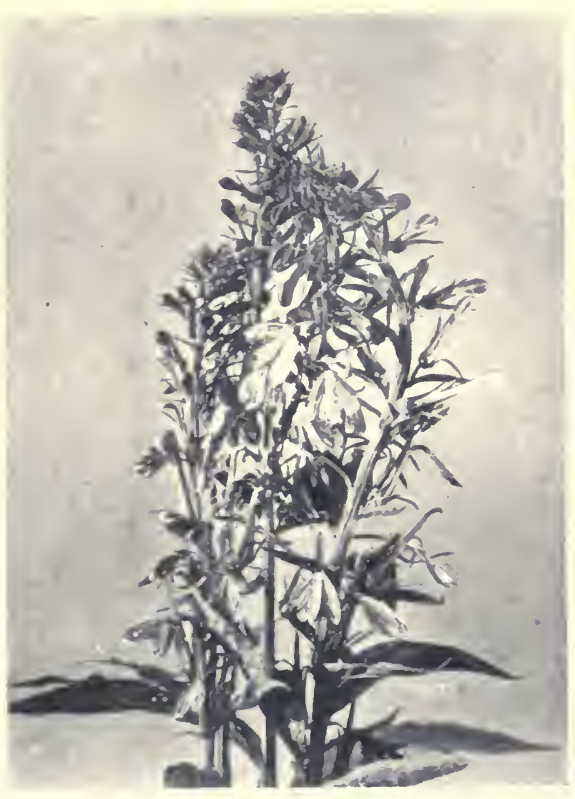

Cardinal flower 


\section{How to Attract the Birds}

poising on rapidly vibrating wings before first one inverted horn, then another, until he circles the flower and drains each tube with ease, it will be seen that, in making this round, his forehead and bill must wipe off some of the pollen from the golden tassel of stamens which protrudes from the older flowers and that in visiting the newly opened columbines in the stigmatic stage, he must necessarily leave some of the vitalizing dust on them. Thus the columbine compels its chosen guest, all unwittingly, to do its bidding.

After the columbine has faded, which is the next flower to lure the ruby-throat? Exquisite bright orange-coloured and brown-speckled jewel-weed blossoms hanging at a horizontal from the tender plant which fringes our mill ponds, ditches and streams, appear in July, to last sparingly through the summer. The incurved, slender tip of their horns secrete nectar with whose overflow only the lusty, acrobatic bumble-bee must be content. 'To the abundant white pollen, however, he freely helps himself, and in so doing he may sometimes benefit his entertainer. But the humming-bird, charmed by the bright, graceful flower-and, indeed, who is not?-has no difficulty in directing his tongue around curves; and as he inserts his bill obliquely into the spur while he hovers above, the observer can easily see, on studying the jewel-weed's mechanism, how invaluable his services to it must be. This is one of the plants which bear also cleistogamous, or never opening, self-fertilized inconspicuous flowers. It has found its way into England, and Darwin recorded that there are twenty plants 


\section{The Ruby-throat's Caterers}

producing cleistogamous flowers there to one having the showy blossoms. Since there are no hummingbirds in Europe, why should the jewel-weed waste its energies? Bumble-bees can be its only benefactors there and they are not worth such expenditure.

Glowing scarlet heads of Oswego tea, bee balm or Indian plume, as it is variously called, prove to be next of kin to the scarlet salvia of our gardens, which comes from the tropics and which is there, as here, fertilized by the humming-bird. Certainly, the Indian plume's colour, form, mechanism and blooming season (from July to September) are as perfectly adapted as the salvia's to the ruby-throat, a constant visitor. Even the flower's protruding stamens, and quite frequently the bracts and upper leaves, wear his favourite colour. Where the Indian plume rears its rounded heads fringed with irregularly slender tubes beside a mountain stream, only the cardinal flower can vie with it in splendor.

Everyone who has a trumpet creeper on the walls of his home knows how irresistibly attractive to the ruby-throat are its clusters of large, tawny red tubes outstretched to hail him. Occasionally the vine escapes from our gardens at the North, but from New Jersey to Illinois and southward to the Gulf it grows wild in Nature's garden, blooming in August and September. Flashing, whirring, darting about the gorgeous flowers, their guest feasts with perfect satisfaction for do they not offer all he desires?

Why should the exquisite cardinal flower deck itself in incomparable red while its twin sister, the great lobelia and its lesser kin wear blue? Watch 


\section{How to Attract the Birds}

the contented bees buzzing about the latter shorter tubed group and then the ruby-throat poised in ecstasy before the long-tubed cardinal flowers in September, if you would distinguish their true motives.

How delighted must the humming-bird have been when we first added to our gardens-and his menu-his favourite salvias, cannas, nasturtiums, balsams, scarlet runner, fuschias, pelargoniums and gladioli, among many other welcome plants imported from warmer climes! These, while unnatural, unexpected rivals to wild flowers which undertook to feed him, earn our threefold gratitude for bringing him to our very doors, causing his numbers to increase and prolonging his stay until frost blackens the once gay garden beds. Not till then does he leave them for the tropics.

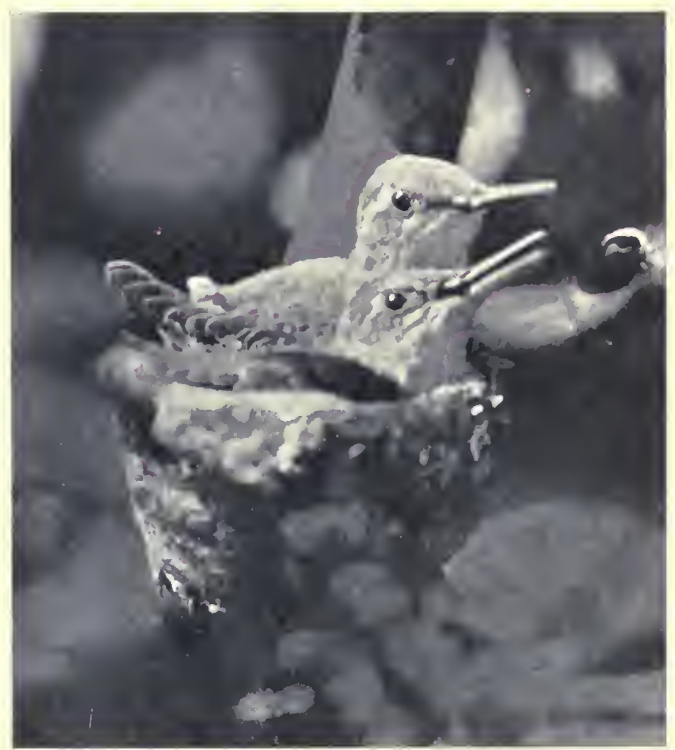

Young birds in the nest 


\section{BIRD ARCHITECTURE}





\section{CHAPTER III}

\section{BIRD ARCHITECTURE}

JUsT as surely as the peoples of the earth have each a characteristic style of architecture, a Hottentot hut or an Indian tepee, a Moorish mosque, a Gothic cathedral or a Chinese pagoda being stamped on its face with the racial individuality of the designer, so the humblest home of the birds about us tells at once to the practised eye the species of the feathered architect who made it. The "dangling cup of felt" is quite as characteristic of the Baltimore oriole, for example, as the temple with its rows of profusely ornamented columns was of the Corinthian Greek. And the marvel is that, guided only by instinct, the birds should continue to repeat generation after generation the special architecture of their ancestors without taking the pains to study a finished model or standing by to watch the expert masters of their craft at work. For birds reared in captivity build as good homes and by precisely the same model as the wild birds of their species. Nor does any bird servilely copy the nest of one not of his own tribe. It would be difficult to name the style of architecture to which most of our modern suburban villas belong (unless we call it the Conglomerate); but every farmer's boy can tell at a glance the robin's mud-plastered nest from the song sparrow's or bobolink's grassy cradle. Primitive 


\section{How to Attract the Birds}

creatures of necessity have singleness of purpose; it is only when we imperfectly civilized humans be-

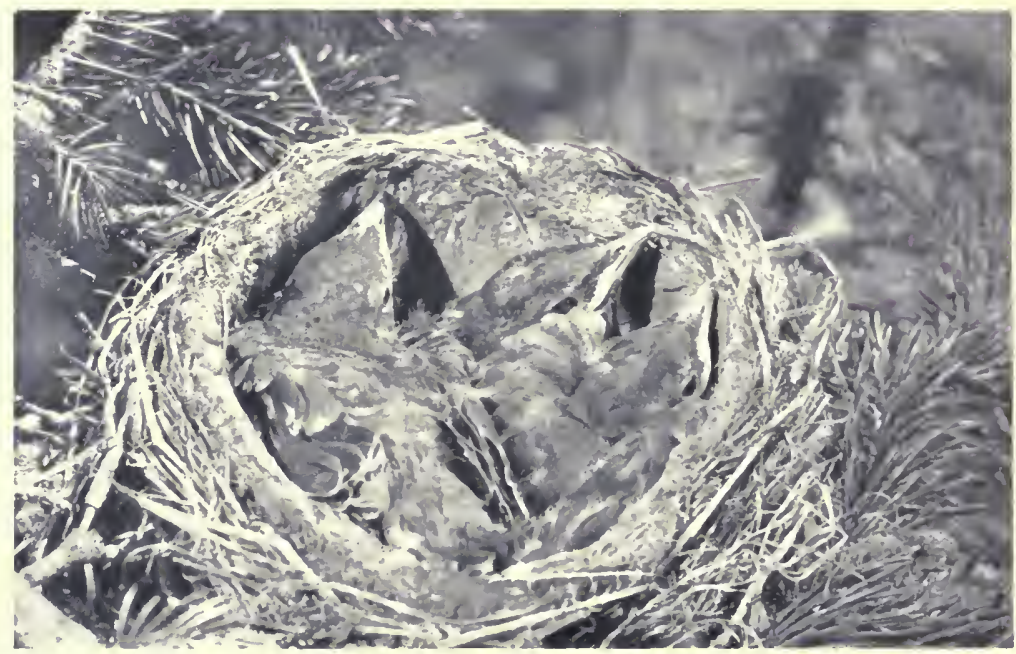

Photograph by Carlin

The robin's mud-plastered nest

come bewildered by the multiplicity of ideas presented for us to choose from, that we are in danger of losing our natural simplicity.

\section{INDIFFERENT BUILDERS}

Ages and ages ago when the first birds evolved from reptiles (from which all are descended) it is probable they neither built nests, nor incubated their eggs, but left them for the sun to hatch, just as the reptiles leave theirs to this day. Birds of the lower orders are still indifferent builders when ther build at all. A depression in the earth, such as barn-yard hens and ducks make with their bodies, and the 


\section{Bird Architecture}

gradual addition of grass, leaves and feathers to give comfort as well as to retain warmth, were certain marks of progress. Even before $\mathrm{th} \mathrm{e}$ days of the steam plough or the mowing machine, - the birds' Juggernaut, -there were ten e $n$ emies of the nests on the ground to one in the trees; and it did not take very highly developed birds to perceive $\mathrm{that} \mathrm{th}$ perches on which th e y themselves sought safety from snakes, rats, mice

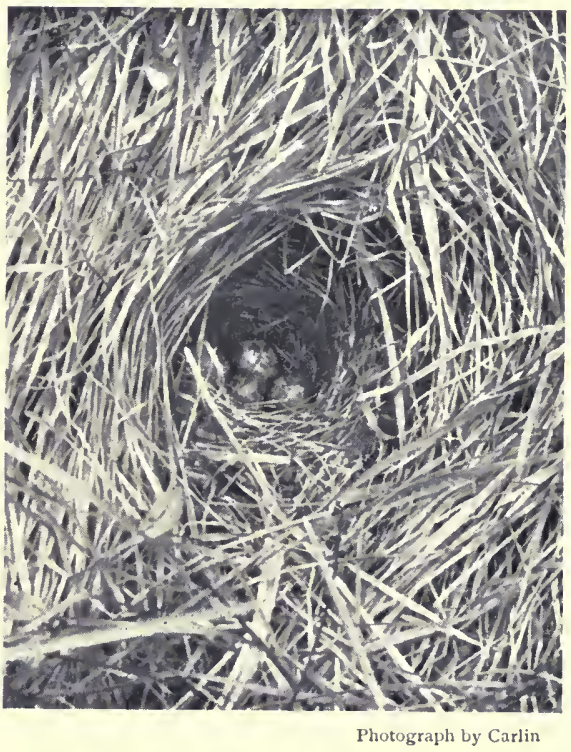

The song-sparrow's grassy cradle and the larger prowling animals, might support a nursery. Fear has ever been a powerful spur to achievement. Stiff sticks, unyielding twigs that by no possibility could be woven into a cradle were simply piled in loose heaps on the limb of a tree; yet these crude lattices mark the first step in the evolution of bird architecture. On such bare slats the young of herons, egrets, pigeons, doves, cuckoos and many other birds that come into the world naked or with a thin coat of down, at most, to protect their tender flesh must spend an unusualiy long and helpless babyhood. Quite naturally, then, the next step forward was to carry the mattress of 


\section{How to Attract the Birds}

grass, moss, leaves, hair, fur or feathers into the tree. When some birds had learned to weave these materials into a cup-shaped cradle (the second step), and choicely lined it (the third); finally when a few of the number actually expressed a sense of the beautiful in the exquisite neatness, symmetry and adornment of their home, their architecture became an art indeed. The nest had stood for love and duty before; now with the higher development of the intellectual and iesthetic sense of the home-maker came new delight in achievement. Imagination awoke.

But it must not be inferred that all the intelligent birds nest in trees and all the stupid ones remain on the ground. In a later paper we shall see that the terns and other sea birds which place their eggs among the pebbles on the beach, and the ruffed grouse which lays hers among dead leaves in the woods, and the night hawk which frequently chooses a depression in a bare rock to cradle her treasures, show just as much intelligence as the most expert weaver.

\section{TUNNEL BUILDERS}

The belted kingfisher and the bank swallow secure protection for themselves and their young, not by nesting in the trees, but by excavating a hole in a bank, preferably one that is steep enough to discourage intruding climbers. It usually takes a fortnight of hard digging for the kingfisher to tunnel four feet deep, so that when a home is found twice that depth with ample nursery accommodations at 


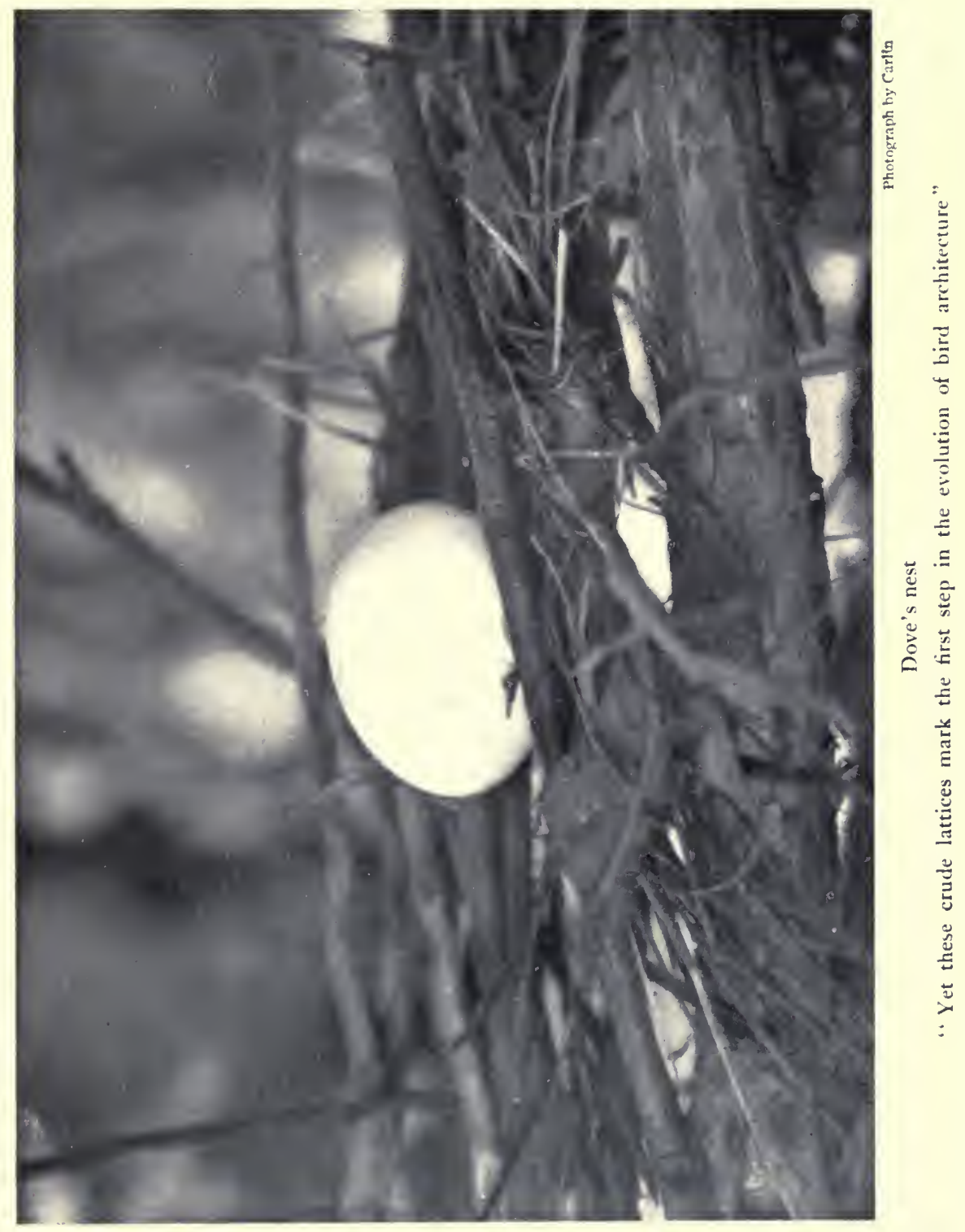



Bird Architecture

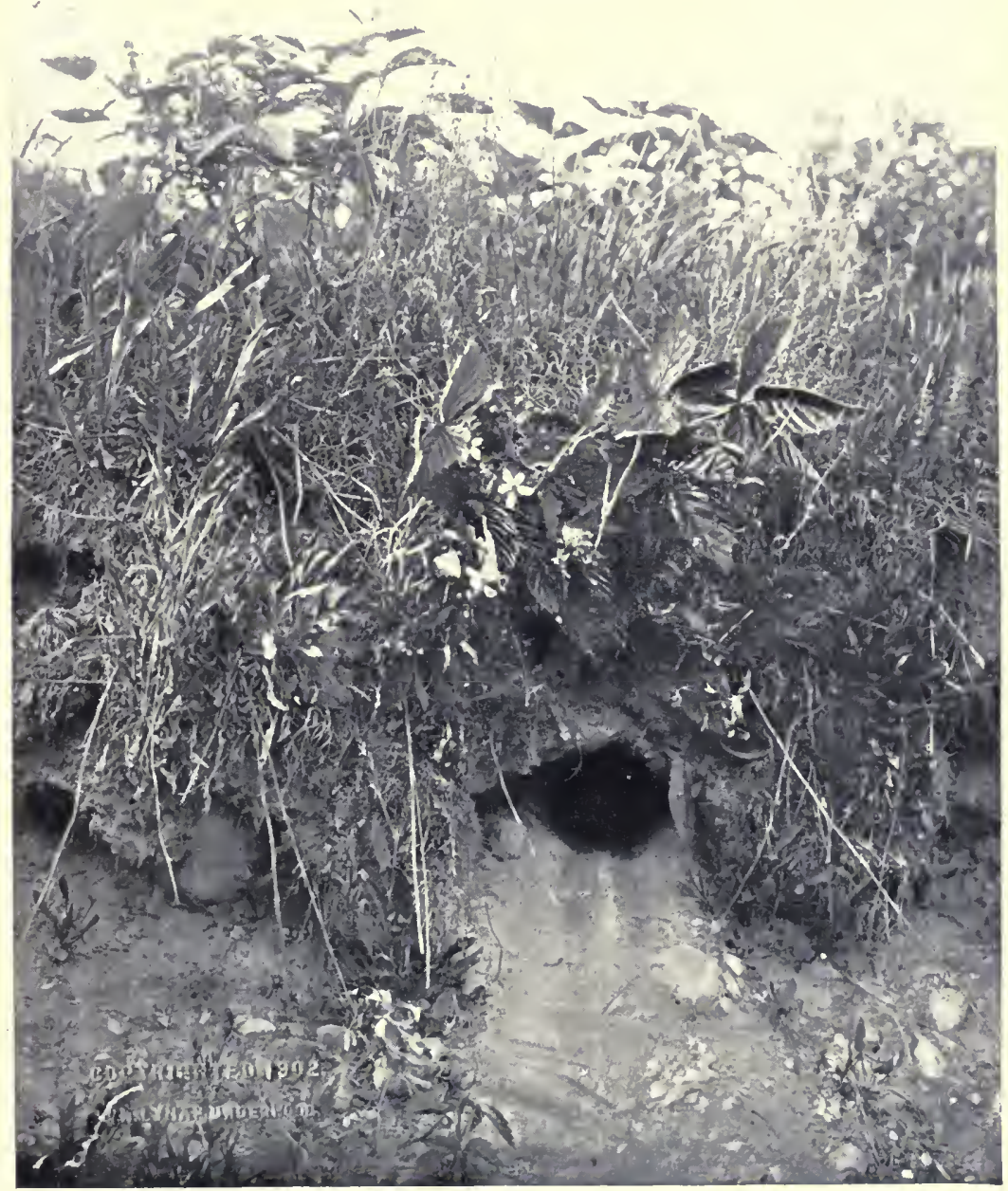

Copyright, s9o2, by Wm. Lynan Underwood

Opening to the four-foot tunnel of the belted kingfisher

the far end, we can easily imagine the labour involved. No wonder the birds become devotedly attached to this place of refuge from the storm and 


\section{How to Attract the Birds}

fortress against enemies. One might suppose that parents capable of so much hard work would do just a little more and provide a comfortable bed for their babies. Not they! Disgorged fish bones and scales form the prickly cradle.

The bank swallow, like all his kin, is fond of associating with large numbers of his fellows even

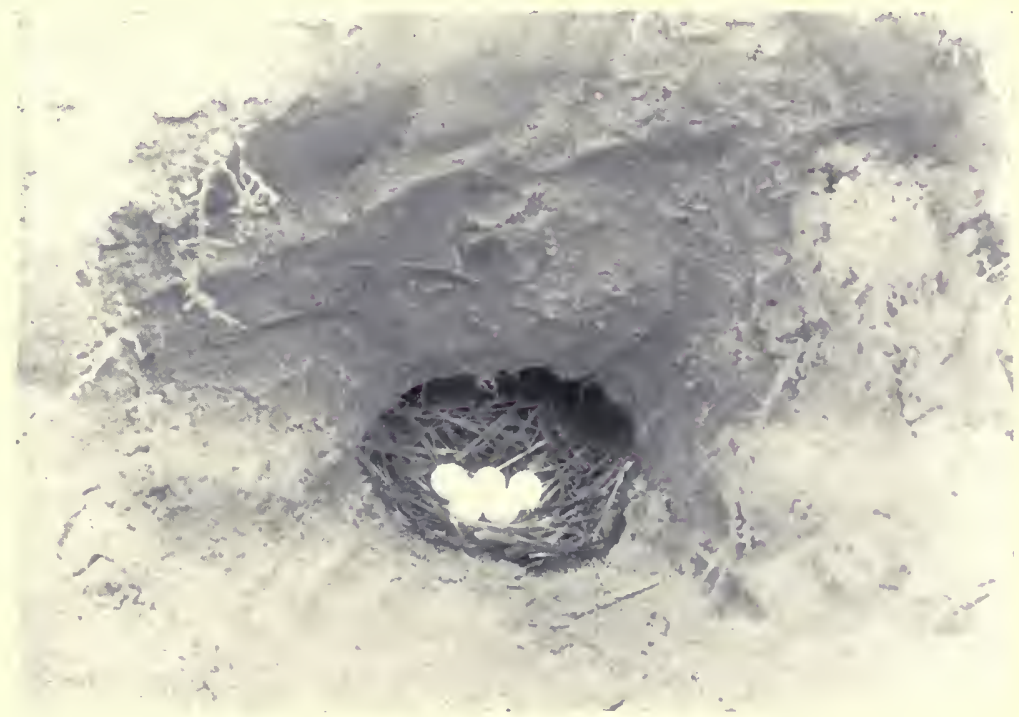

l'hotograph by Brownell

Bank swallow's nest and eggs. (Burrow in the sand opened to show nest)

at the nesting season. The face of an entire bank where a colony of these graceful birds elect to live will be drilled with holes as if it had been used as a target by soldiers practising with small cannon. To dig at least twenty inches into the sandy bank is no slight task for so small a bird, which still has energy enough remaining to carry twigs, grass and feathers into the end of the tunnel. 


\section{Bird Architecture}

\section{CARPENTERS IN FEATHERS}

Not a few birds which like to hide away in deep holes prefer not to be underground and if they

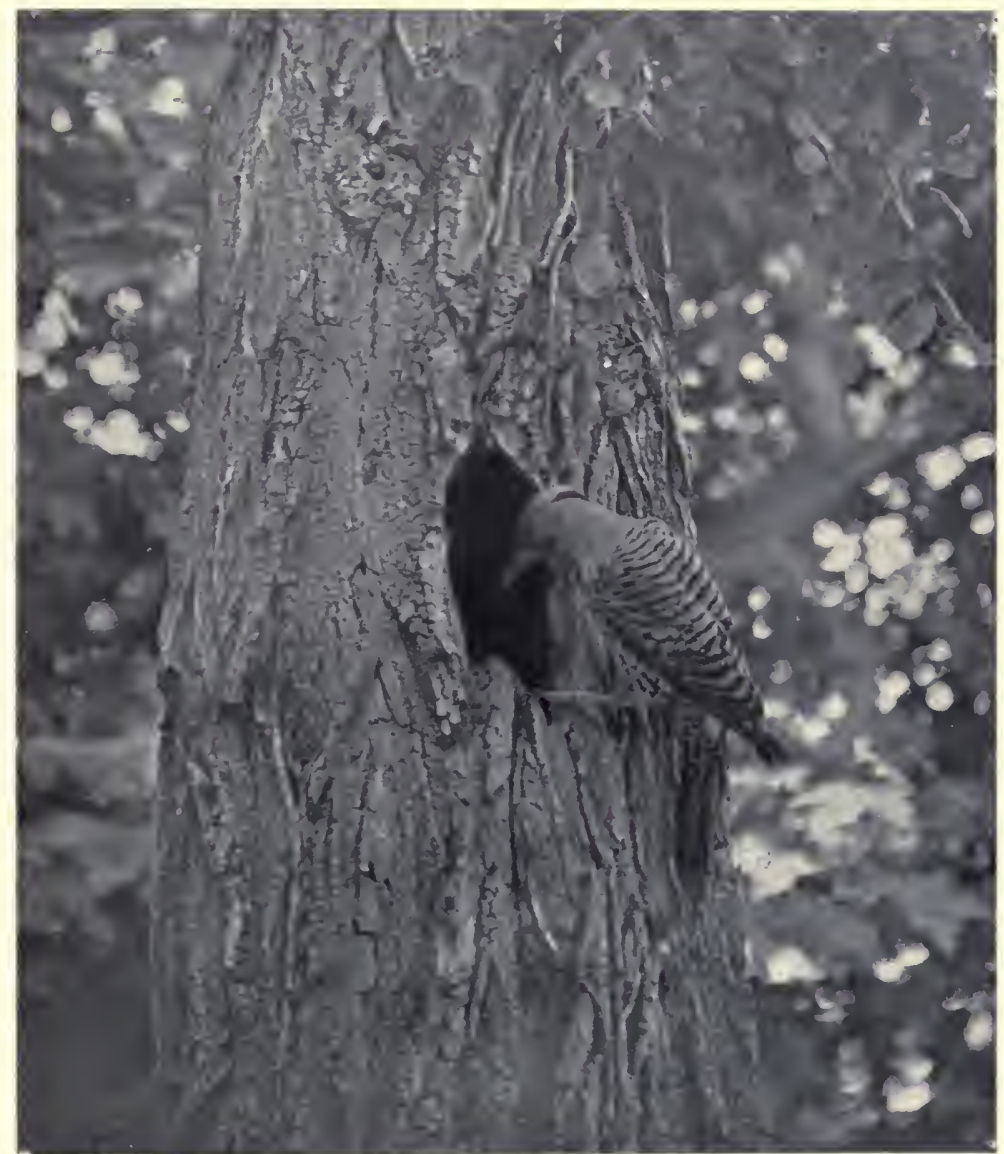

Photograph from tife by A. L. Hercehorn

A master carpenter-a flicker at her hole

do not find a hollow tree what is there to do but use their stout bills as chisel and hammer to hollow 
How to Attract the Birds

out a tumnel to their liking? Of course, the master carpenters are the stockily built woodpeckers whose deserted homes many a bluebird, owl, tree swallow, wren or woodduck is thankful to occupy. First a

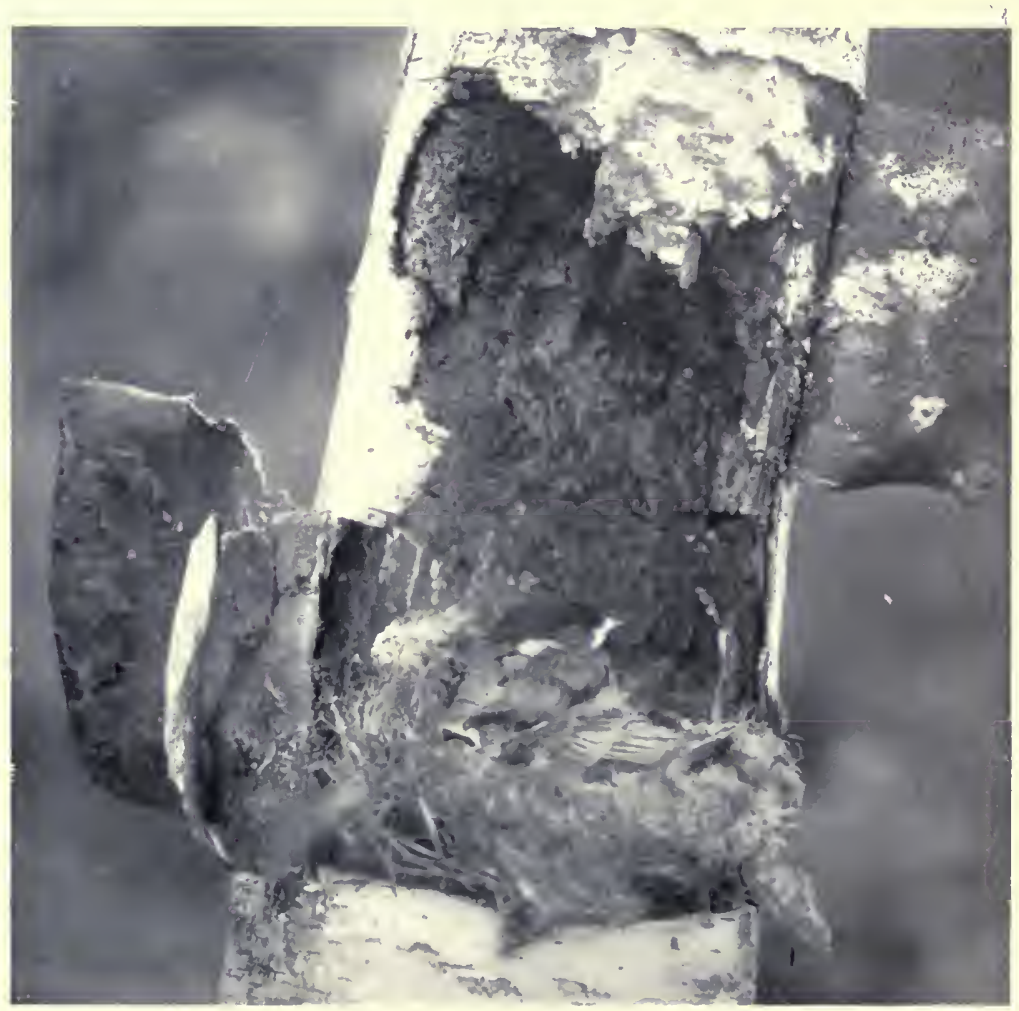

Photograph by Dugmore

The chickadees swelter in a lining of fur and feathers

circle of holes, more perfect than you or I are likely to draw, is drilled on the trunk or larger limb of a tree. Naturally, a partially decayed one is preferred. After the circular doorway has been cut out, how Mr. and Mrs. Woodpecker, working in 


\section{Bird Architecture}

turn, make the chips Hy! To chisel two or three inches of sound or even partially decaved wood is a full day's work; yet, if for any reason the pair of carpenters become disgusted with the site, they do not hes-

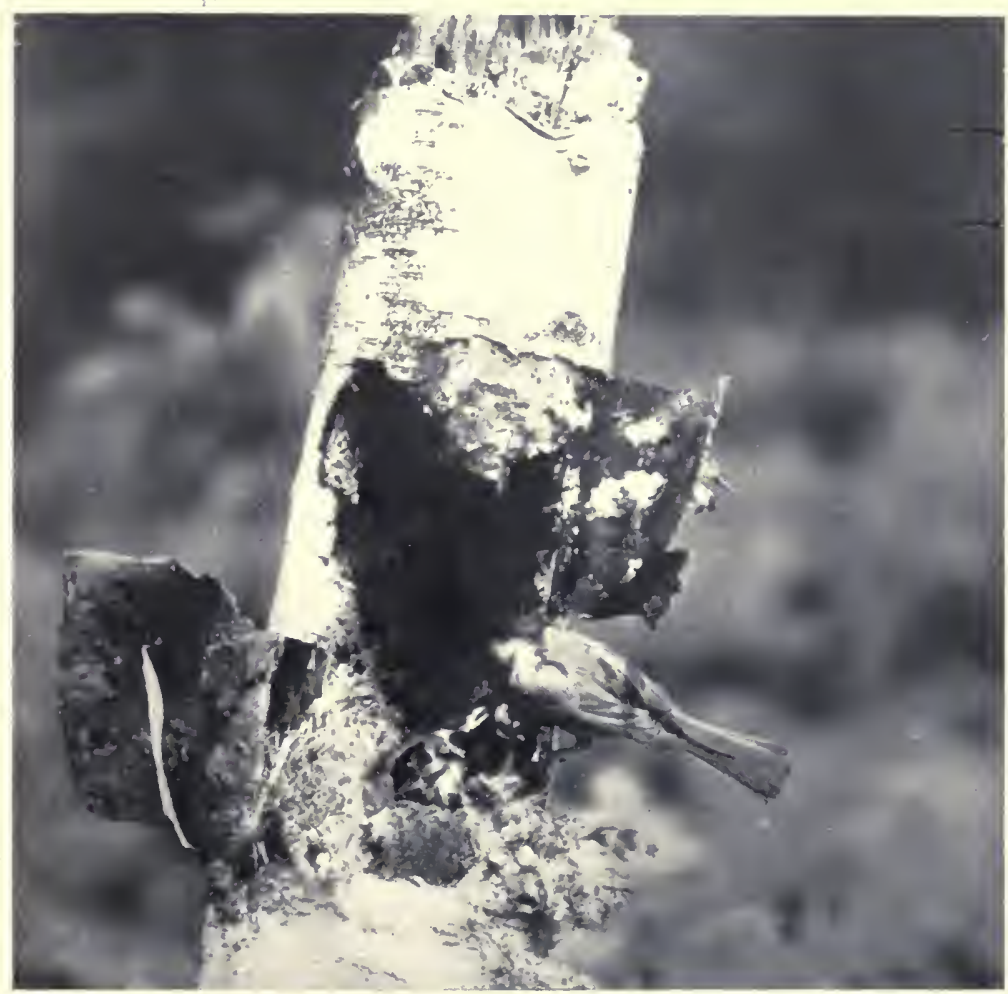

Photograph from life by Dugmore

Chickadee and young (nest opened)

itate about beginning another tunnel, another and still another, in different trees until they finally complete a horizontal passage descending abruptly into a pearshaped chamber. Truly the workman is known by his chips; here the finer ones remain in the nest 


\section{How to Attract the Birds}

and form its lining, whereas the nuthatches, titmice and chickadees, which live in similar homes,

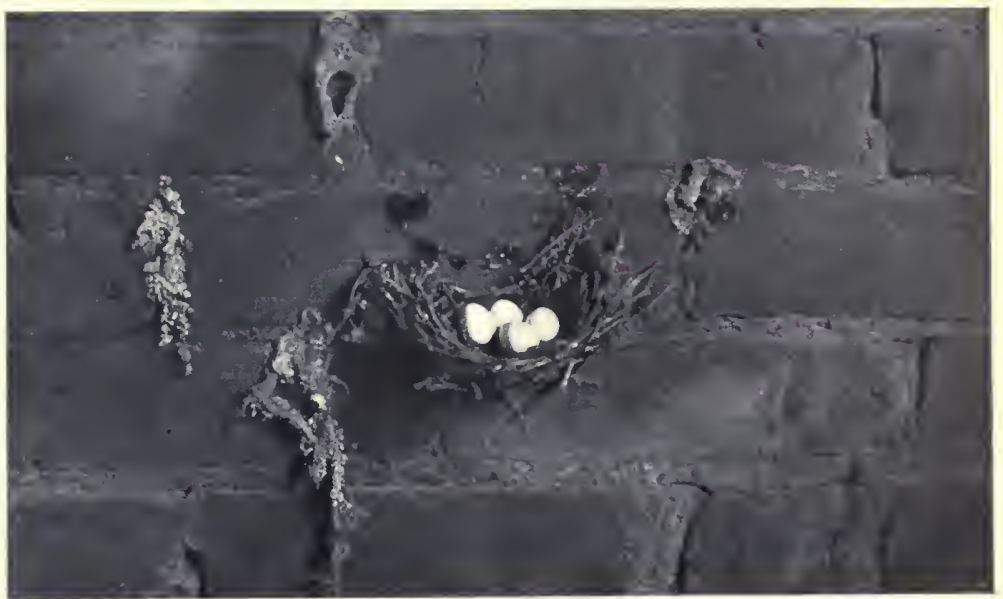

The chimney swift's wicker cradle which the bird glues to the bricks

swelter in a lining of fur or feathers, probably because their hardy ancestors, living at the far North, needed warm bedquilts which their more widely travelled descendants are too conservative to discard.

\section{PROGRESSIVE MOTHERS}

Occasionally a bird is strong minded enough to break away from old traditions. Before this country was settled, the swift also nested in hollow trees; but after trees began to be cut down and chimneys arose above the roofs of houses everywhere, the birds were quick to perceive that fires are generally out by their nesting season; therefore, why not take advantage of the innovation? So completely did 


\section{Bird Architecture}

they forsake their old nesting sites to build in chimneys that the name chimney swift is now universally applied to them. (They are not swallows; not even related to them, however frequently one hears them miscalled chimney swallows.) At the nesting season the saliva glands become much enlarged and with the mucilage-like fluid flowing from them the birds glue their wicker cradle together and hang it on the bricks inside of the chimney. The mucilaginous nest of our swift's Asiatic relative is much sought by Chinese epicures.

We now speak of house wrens as if it had always been the habit of these friendly littie birds to live under the eaves of our houses or in the boxes set up for them about the home grounds; but, before there were houses on this continent they, too, nested in tree hollows and do still when a satisfactory natural shelter can be found.

The exquisitely beautiful little woodduck, cousin of the Chinese Mandarin duck, likewise shows remarkable indepen-

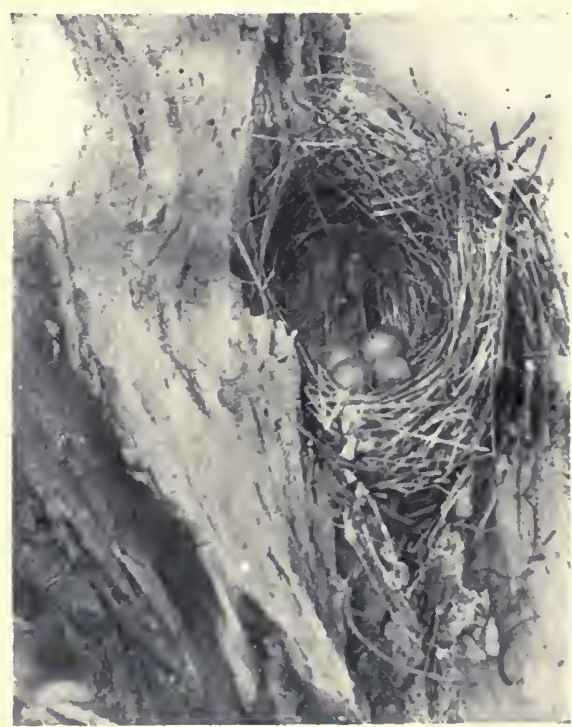

Wrens formerly nested in tree hollows dence to nest in a hollow tree while nearly all her relatives place their eggs either on the ground, in a 


\section{How to Attract the Birds}

tussock of grass or in a floating mass of leaves and muck. Since baby ducks can swim long before they can fly, this strong-minded little mother will-

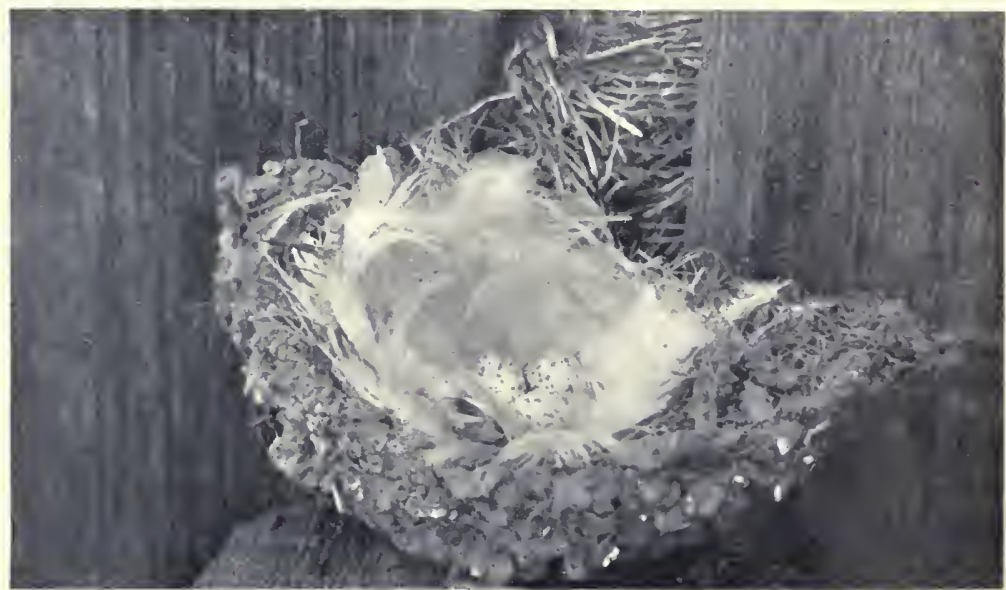

The barn swallow hangs its clay bracket against the rafter

ingly carries hers to the lake in her bill, much as a cat carries her kittens, rather than risk the loss of her eggs on the ground from the depredations of water rats.

\section{TRADES REPRESENTED.}

The tailor bird, one of the warbler tribe living in the East Indies, which sews leaves together to form a cradle, cannot be named to swell the list of trades represented in our birds' architecture; but we have many expert weavers, carpenters, felters, masons, moulders, decorators and a few professional hum-bugs. The barn swallow, manufacturing bricks without straw, hangs its clay bracket against the 
rafters; the Baltimore oriole makes a unique pouch from fine grasses, hair, string, plant fibre, down, woollen or cotton strips, felting the numerous materials into a thin but wonderfully strong materia! that neither storms nor the weight of a family can tear where it hangs from the tip of a high branch well beyond the reach of snakes and small boys-equally unwelcome visitors from the bird's point of view. Birds are exceedingly particular about the materials for their nests; even the slovenly, amorous dove rejects one stick in preference to another for her rickety lattice. The little, chipping sparrow will have horse hair, that and nothing elsein the world, to line her cupshaped cradle. The goldfinch chooses thistledown for her upholstery. After a heavy rain, how many robins' nests fall to the ground! This is because the unfortunate masons used mud among the grasses in the cradle rather than sticky,

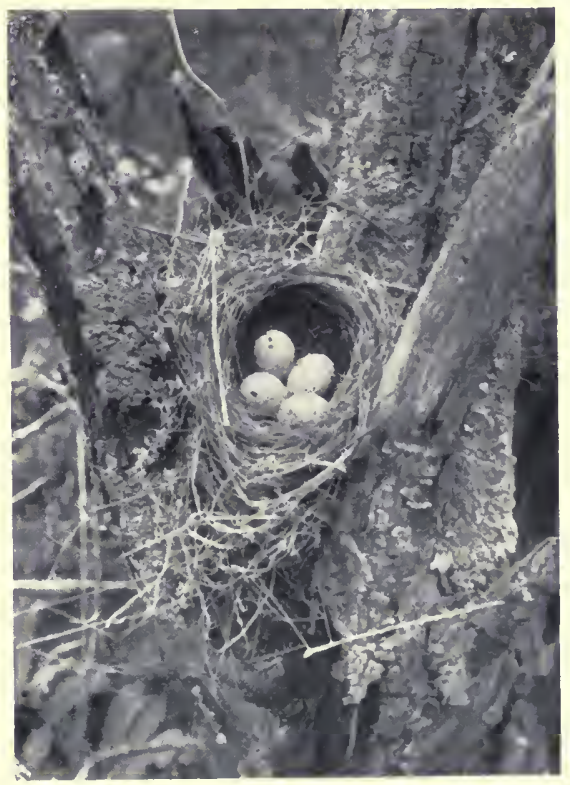

The little chipping sparrow will have horse hair, that and nothing else in the world, to line her cup-shaped cradle impervious clay, which, unhappily, is not always to be found The phoebe, cementing her exquisite nest of moss and 


\section{How to Attract the Birds}

lichens with mud, and lining it with hair, saves it from similar destruction by placing it under bridges, cliffs and the eaves of piazzas. Like a miniature Dutch oven is the nest of the golden-crowned thrush, whose domed nursery only the sharpest eyes can detect among the leares on the ground in the woods.

Which are the best decorators among birds? While many show true strivings after the beautiful, one hesitates between the parula warbler and the humming-bird before awarding the palm, for the former will consent to live only where she can gather the graceful gray moss to festoon her nest, while the latter builds the daintiest, downiest, tiniest nest imaginable, then stuccos it with bits of lichen for the purpose of concealing this masterpiece of architecture, no doubt; but surely this æsthetic little creature is also influenced by a sense of beauty.

Which birds then are hum-bugs? If the marshwren, which goes to the pains of building a number of nests among the tall grasses in the same vicinity for the purpose of misleading intruders, does not belong in this category, the dusky crested flycatcher certainly does. This "wild Irishman among birds" scours the country for cast snake skins to place in his nest; but when this bugaboo cannot be found he has had to content himself more than once with the skin of an onion! At a catbird's imitation of pussy's mew, even the house-dog pricks up his ears. The yellow-breasted chat will lead you a sorry chase, throwing his unmusical, ventriloquous voice now into the cat-brier tangle across the stream, norv among the undergrowth far beyond. 


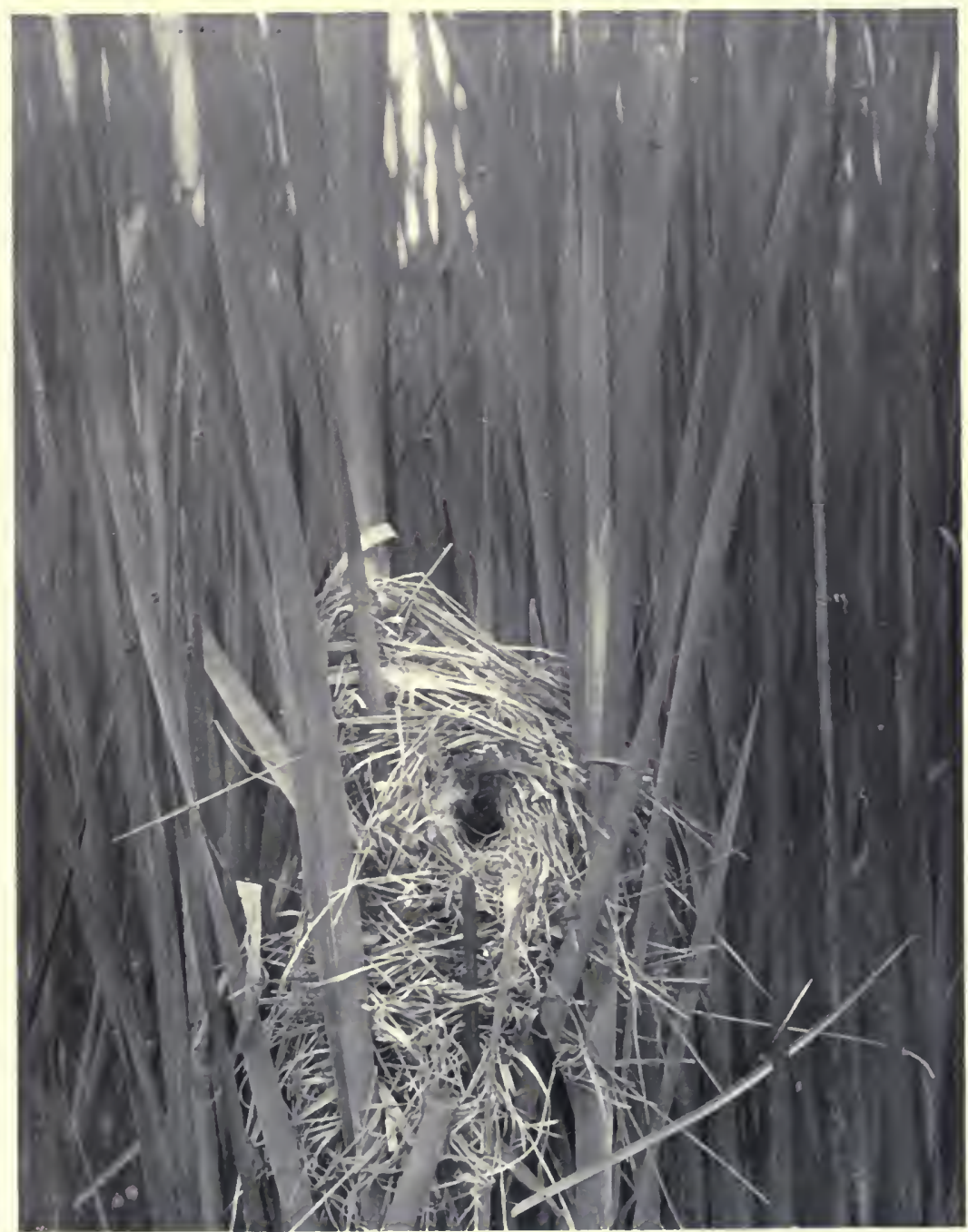

The marsh-wren goes to the pains of building a number of nests to mislead the intruder 



\section{Bird Architecture}

HOW THE YELLOW WARBLER OUTWITS THE COWBIRD

There are still many lazy, slovenly, indifferent, commonplace or utilitarian home makers among undeveloped or degenerate birds as among humans, but happily only one of our birds disgraces itself, like the European cuckoo, by refusing to make a home and to perform any domestic duties whatever. When other virtuous nest builders are working and singing from morning till night, the cowbird, a dark, silent, decadent relative of those charming songsters, the oriole, bobolink and meadowlark, skulks about alone, slyly looking for the chance to drop an egg in the nest of some little warbler or vireo-any small, weak, tender-hearted foster-mother she can find-leaving to various such victims the labour of hatching and rearing her scattered brood. A serious task indeed awaits the over-burdened little mother who must feed a great gaping gourmand in the cradle with her own crowded and half-starved babies.

But there is at least one ingenious little architect among the cowbird's special victims whose wits frequently save it from such misfortune. Finding a strange egg in its cup-shaped nest and being unable to roll it out, the yellow warbler proceeds to weave a new bottom, effectually sealing up the cow-bird's egg and preventing the heat from her brave little heart from warming it into life. Suppose this "wild canary," as it is often called, had already laid her own eggs in the nest at the time of the cowbird's visit: what then? In this case the warbler does not hesitate to sacrifice them, sealing them up with the cowbird's by weaving a new bottom above them, 


\section{How to Attract the Birds}

rather than hatch out one interloper to worry and starve her brood. Where a second persecution has taken place, two new cradle bottoms have been woven. If you ever have the good fortune to find a two or three storied nest, you may be sure it belongs to this little Spartan mother.

\section{THE CLIMAX OF BIRD-LIFE.}

For special and excellent reasons of their own, some birds may build earlier in the season, some not until midsummer, but for the great majority May is the month of happy achievements; jealousies of courtship have given place to blissful content; every moment is filled with happy, profitable labour. Sometimes both lovers busy themselves with the home building; perhaps the wife does all the manual work, while the mate merely makes her pretty speeches, approves her every act, applauds her industry, her skill, cheers her by his constant presence and such music as love alone inspires. What of that? She is perfectly satisfied; these May days are her realization of Paradise. Whatever is best in the nature of both mates at least temporarily triumphs over the base; for however selfish birds may be at other seasons, in May they are truly one in purpose and sympathy. According to their temperament, some work impulsively with outbreaks of rollicking ecstatic, passionate song like the wren, or with steady persistence and the serene hymn of the thrush. At last the end crowns the work: the building of the nest embodies all that is greatest in a bird's life. 



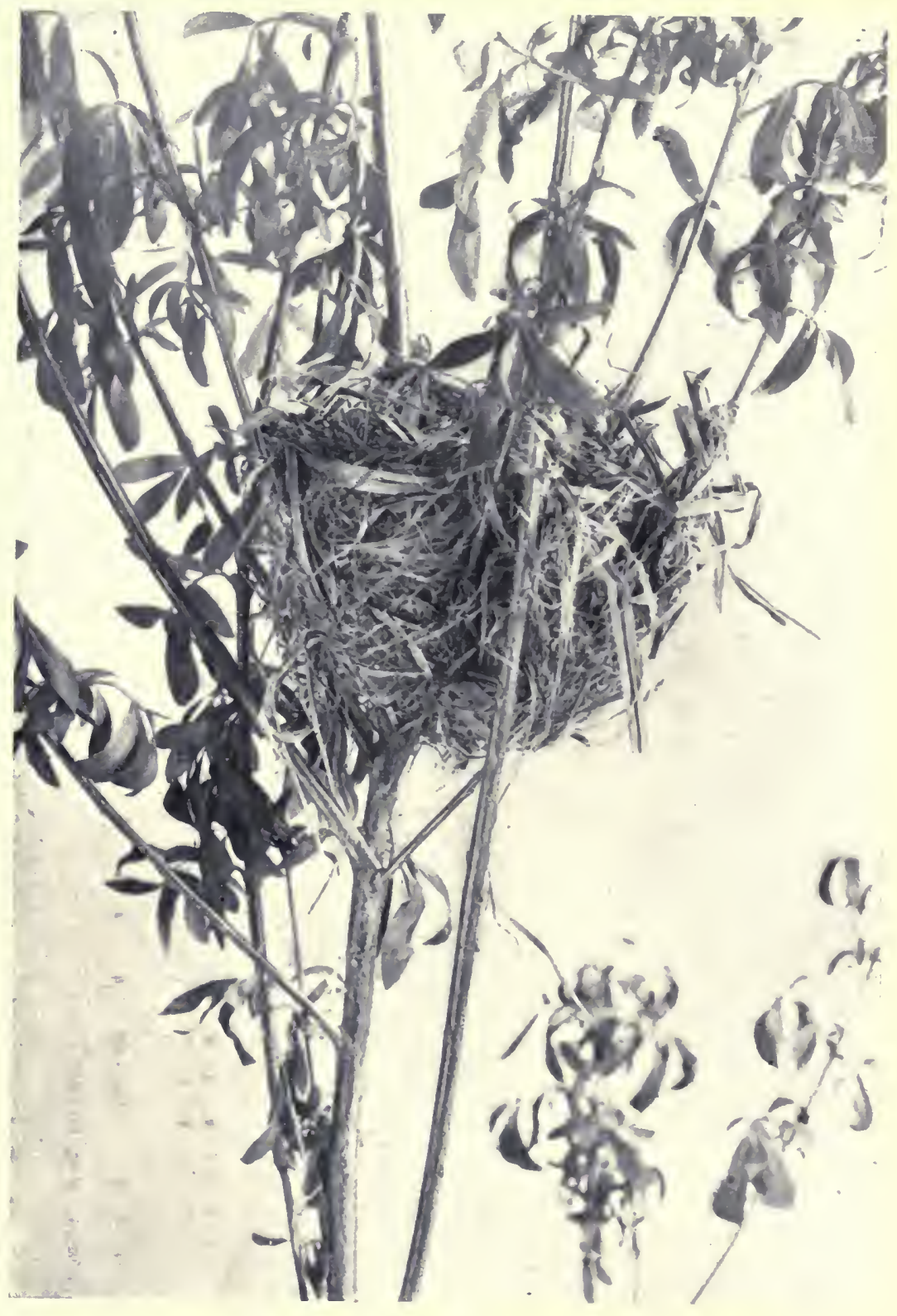

Yellow warbler's nest, normal shape 


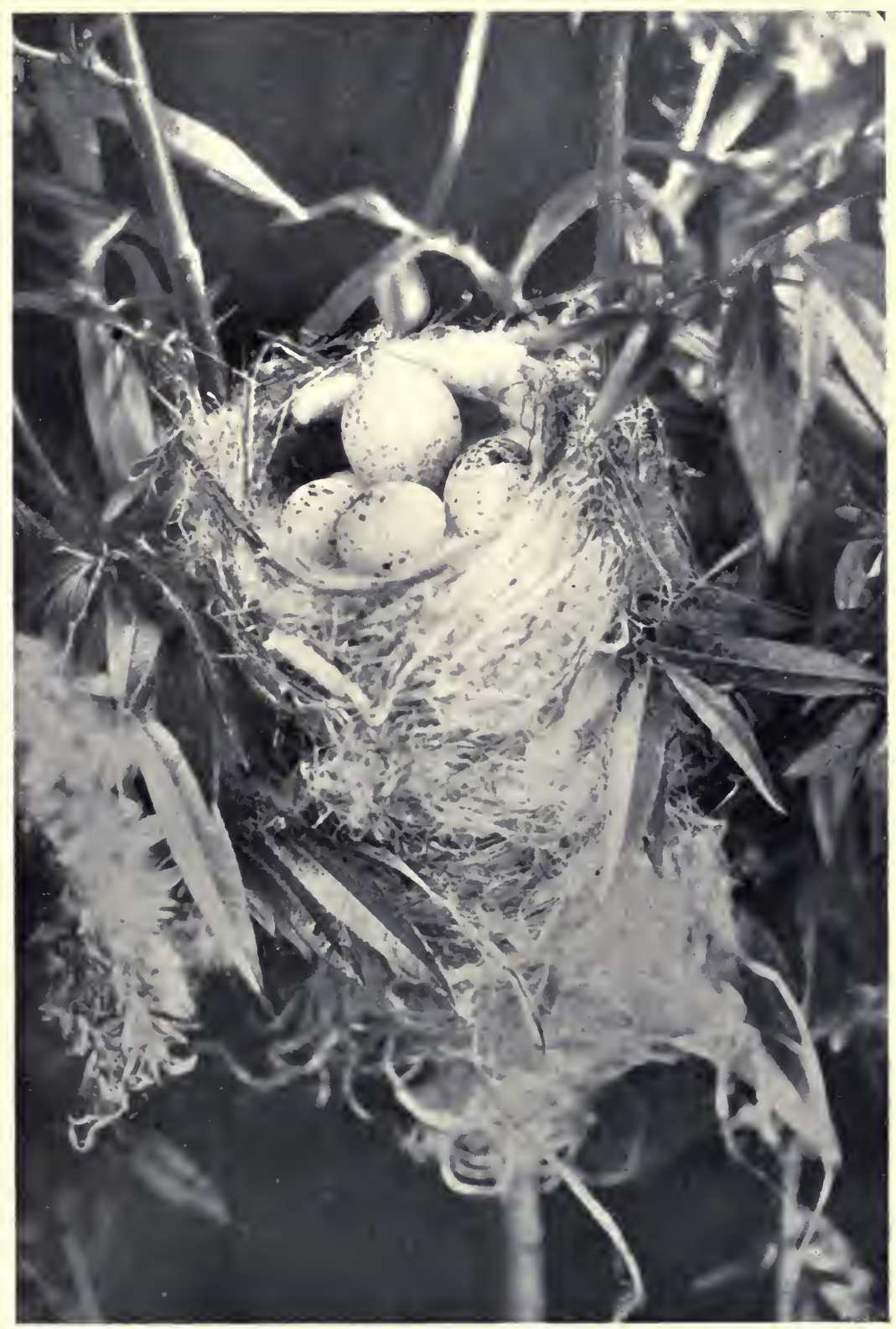

Yellow warbler's nest, showing how the bird has rebuilt because of repeated persecutions of the cowbird. (One cowbird's egg in the nest even now) 



\section{HOME LIFE}





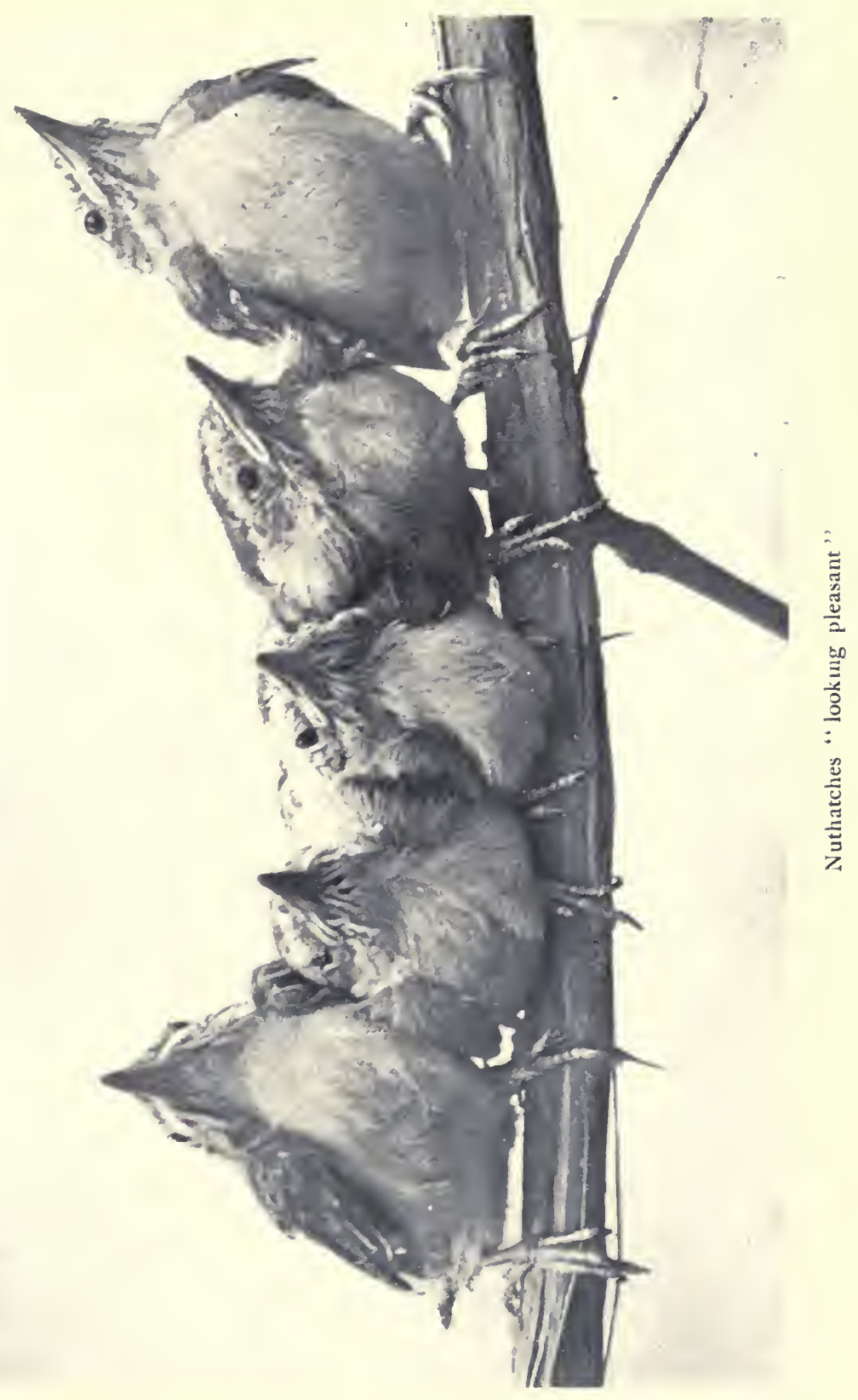





\section{CHAPTER IV}

\section{HOME LIFE}

SHARP, ringing cries of alarm, then of terror, coming from a pair of robins one morning in June, caused me to drop my work suddenly, dash out of doors and follow the sound through the garden, across the lane to a meadow where a vagrant cat, with a now-or-never desperation, made a leap through the grass even as I approached and, before my very eyes, snapped up a baby robin in its cruel jaws. With as frantic a leap upon the cat, I quickly pried its jaws apart and released the limp and apparently dead bird. Three other young robins, which had fallen out of the same nest in the cherry tree when a heavy thunder shower weakened its mud-plastered walls the night before, were squatting dejectedly on the ground, unable to fly. So I gathered them up in my arms too, lest they fall a certain prey to the cat, and deposited the little family in an improvised flannel nest on a sunny upper balcony.

One might have supposed that the parents would find them here, within fifty yards of their cherry tree home, and come to feed them. Strangely enough, the old birds' cries of distress were the last sign from either of them in the neighbourhood. Did they flee the place in despair, thinking their babies foully murdered by the cat and me? After waiting in vain for some response from them to the 
How to Attract the Birds

incessant, insistent cheep, cheep, from the balcony nursery, I could resist the cries of hunger no longer. Even the baby which had been literally snatched

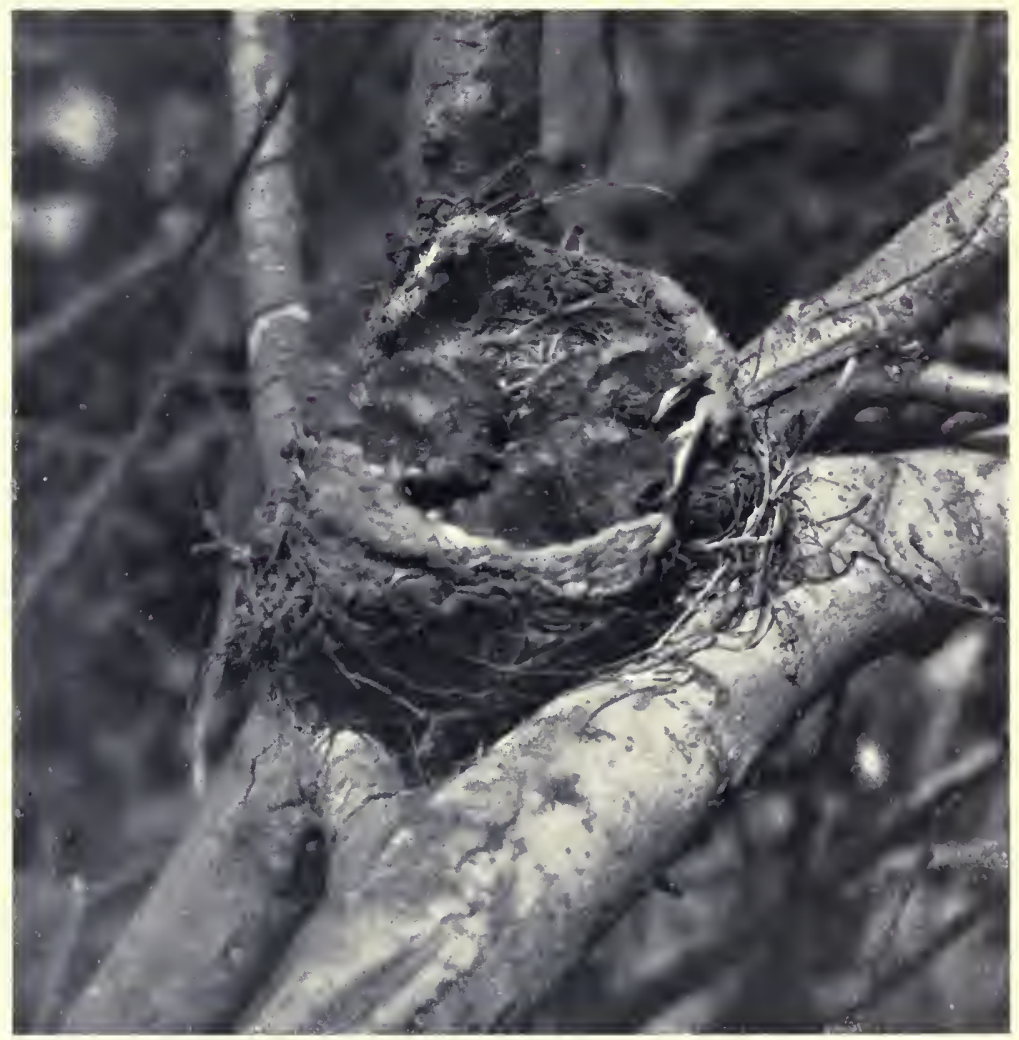

A thunderstorm weakened its mud-plastered walls

from the jaws of death had now recovered from his fright, not having received so much as a scratch, and was clamouring for food as loudly as the others, jerking himself upright with every cheep, as if stamping both feet with impatience at delay. 


\section{A SIXTEEN HOUR IVORKING DAY}

From that hour my preconceived ideas of bird life were radically changed. Once I had shared the popular notion of birds as rather idle creatures of pleasure, singing to pass the time away, free from every care while they Hew aimlessly about in the sunshine, fed from the abundant hand of Nature. But bringing up those four feathered waifs taught me that birds doubtless work as hard for their living as any creatures on earth. At about four o'clock every morning sharp, hungry cries from the balcony wakened me. Perhaps it was because I was only a step-mother that I refused to go out on the lawn then in search of early worms. Another nap was more agreeably purchased by stuffing each little crop full of the yolk of hard boiled egg and baked potato mashed into a soft paste, the lumps washed down with a tiny trickle of fresh water from a stylographic pen-dropper. Such gaping yellow caverns as were stretched aloft to be filled while the little birds trembled with excitement, jostled one another and scrambled for first turn! Every hour regularly throughout the long day those imperious babies had to be satisfied. Ants' eggs from the bird store, a taste of mocking-bird food mixed with potato and an occasional cherry or strawberry agreed with the little gourmands perfectly. A small boy, who vas subsidized to dig earthworms for them, called the bargain off after one day's effort to supply their demand. Sixty worms had not been sufficient for creatures which eat at least their weight of food every twenty-four hours. 
How to Attract the Birds

Doubtless they were spoiled babies from the first. At any rate they had me completely enslaved; all other interests were forgotten; not for anything would I have gone beyond their call. But real motherly joy in them came when their pin feathers

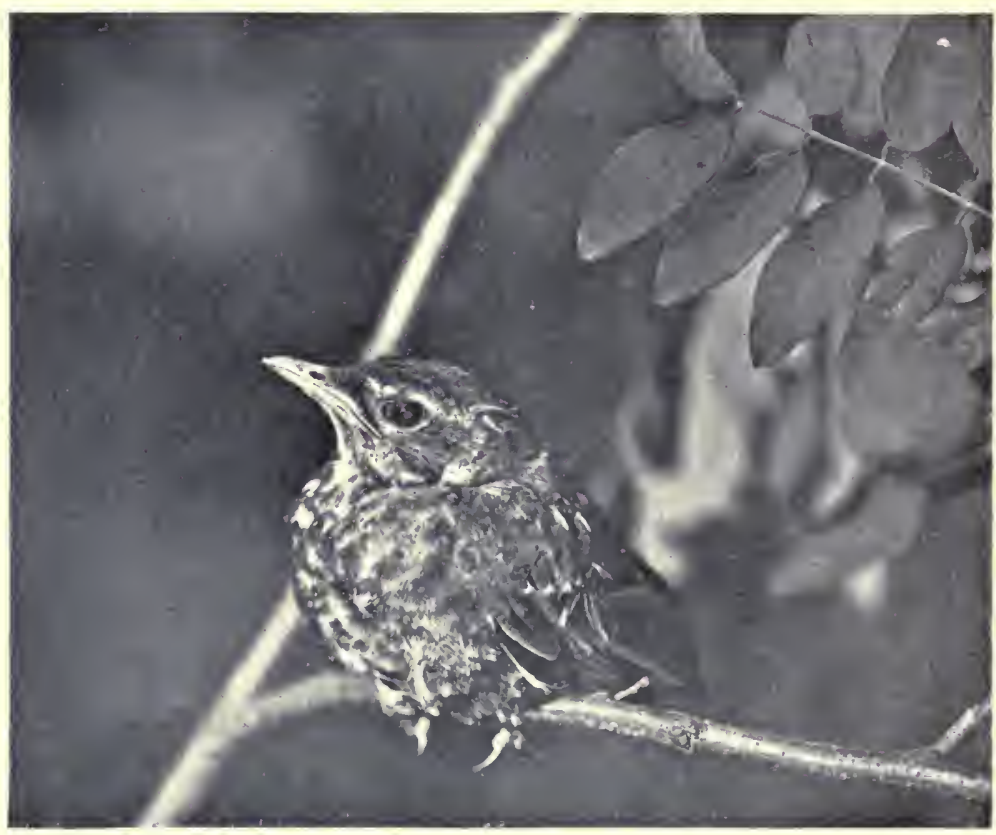

A full crop distended his speckled, thrush-like vest

fluffed out, their legs became stout enough to climb and hop over the wistaria vine on the balcony, stubby little tails fanned out pertly and full crops distended their speckled, thrush-like vests. When, after about two weeks spent on and around the balcony, the last of the quartette spread his strong wings and flew off to the strawberry patch to pick up his own living thenceforth, I realized as never 


\section{Home Life}

before why the alert, military-looking, red-breasted robin of the spring becomes more and more faded and dejected as summer advances, and the joyous song of courting days diminishes until it ceases altogether after the father has helped his mate raise two broods. Yet with my utmost care I had probably not done half for those fledglings that their parents would have done.

\section{WHAT IT MEANS TO REAR A BROOD}

In a state of nature, what would a pair of robins do for their family? After the building of the nest-of itself no small labor-there follow fourteen long weary days and nights of confinement upon the eggs before they hatch. Thenceforth on the average of every fifteen minutes daily from dawn till dark both parents visit the nest, usually bringing in their bills food which they often travel far and work hard to find-earthworms, grasshoppers, locusts, beetles, the larva of insects, choke cherries or other small fruits to be crammed with sharp but painless thrusts into the ever hungry mouths. The second an old bird alights on the home branch, up spring the little heads, every one agape, like Jacks-in-the-box. In their loving zeal, the parents themselves often forget to eat. After every feeding, the nest must be inspected and cleaned, the excreta being either swallowed or carried away. Then the fledglings are picked over lest lice irritate their tender skins. Very many young birds die from this common pest of the nests, especially those whose cradles are lined with chicken feathers, which are nearly always infested. 


\section{How to Attract the Birds}

Birds, like all wild creatures, live in a constant state of fear, but parenthood develops courage amazingly, just as it develops all the virtues. When climbing cats, snakes, small boys, hawks, owls, crows, blue jays, red squirrels and other foes do not threaten the baby robins' safety, either heavy rains, high winds, or fierce sunshine may require the patient

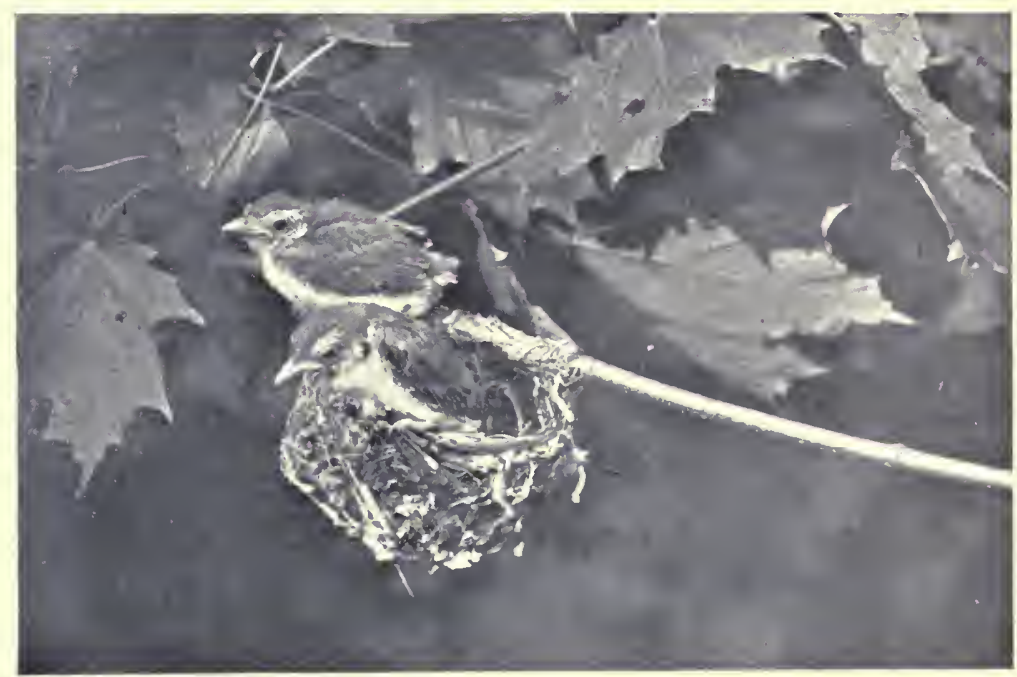

The vireo's education begins

little nnother to brood over her treasures. Before they are a week old their education begins. On the eleventh day, if all goes well, it is usually the mother who utters low endearing baby talk, coaxing the little fellows to hop out of the nest and about it. Coming near an ambitious youngster she stands but does not deliver a tempting morsel held just beyond his bill. Luring him with it farther and farther away, hopping and flying from branch to branch, 


\section{Home Life}

she tantalizes the hungry bajy, perhaps, but she educates him with no loss of time. When finally the young are able to trip lightly, swiftly over the grass after their parents, have learned to cock their heads to one side and listen with the intentness of veterans for the stirring of worms beneath the sod, to capture their own food and fly swiftly out of the presence of danger, their education is considered complete. The remainder they must acquire by experience, for even now their parents may be repairing the old nest or building a new one to receive a second brood.

\section{BABY BIRDS' DIET}

Walking along a hot, sandy road in Florida one morning, I met a young coloured woman with a little baby in her arms, pacing back and forth under a blazing sun. A glance sufficed to show that her baby was ill. It moaned piteously and its skin was burning hot, as well it might be even without fever.

"Come under this tree," said I, "and tell me why you are carrying that baby about in the heat." "'Cause he's sick and I'se waitin' fo' de doctor to happen along dis yeah road."

"What do you think is the matter with your baby?"

"I specks he done eat too much fried fish dis mornin'."

"Fried fish!" I exclaimed. "Why, the baby has no teeth!"

"No'm; he ain't got no teeth yet, but he's powerful fond of fried fish." 


\section{How to Attract the Birds}

A Florida jay, which was noisily searching in the palmetto scrub behind us for a mouthful of food to carry home to her fledglings, was evidently more discriminating in her choice than the equally un-

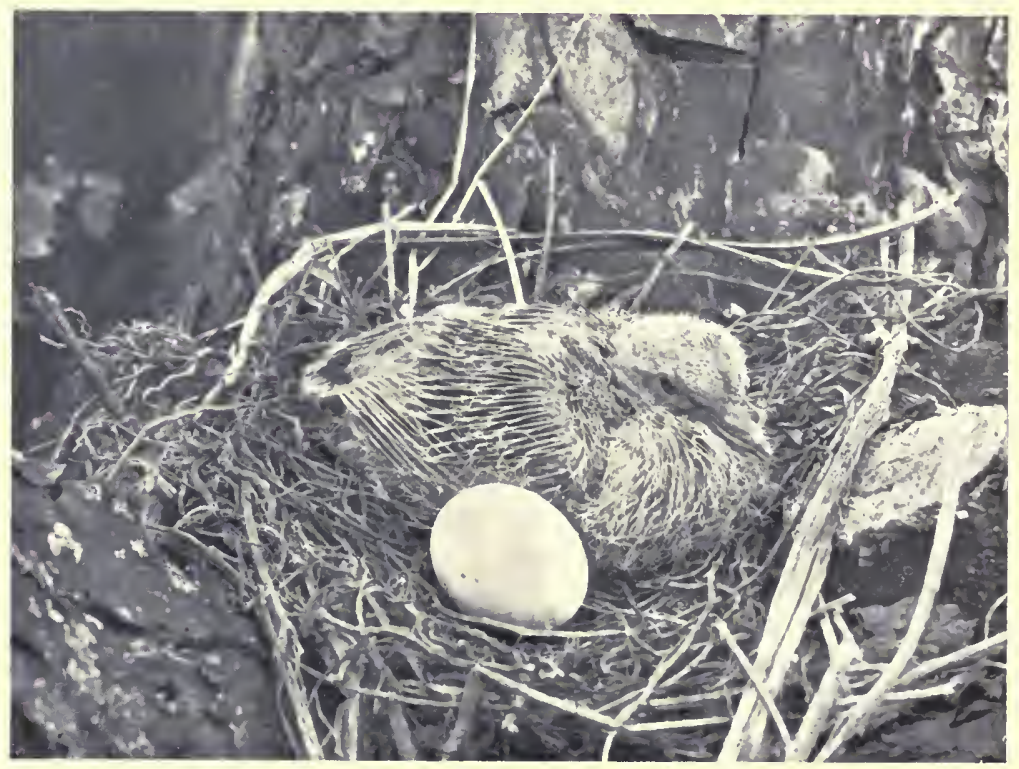

The dove's misrnanaged nursery

taught human mother, for she rejected as unfit many insects which she, herself, would gladly have swallowed.

Many birds have one diet for their babies and another, quite different, for themselves, only the seedeaters reverse our ideas and give their strongest meat to babes. However strict vegetarians certain of the finch tribe may be at maturity, they provide for the nursery a variety of insects. These are not often given alive and squirming, but after they have been 


\section{Home Life}

knocked and bruised into a pulpy condition that is sure to cause no colic.

Even the birds which provide for their babies the same food that they themselves enjoy-which is by far the greater number-usually take the trouble to give it special preparation for the tender stomachs. Having no pepsin, lime-water or sterilizer at command, what could be a simpler way to prepare a perfectly digestible baby food, than to first swallow and digest it themselves, then pump it down the throats of offspring not yet old enough to be squeamish? In this way the young flickers, for example, are fed, but, as far as is known, no other woodpeckers. The flicker, or high-hole, collects a square meal of perhaps two or three thousand ants which partially digest while she is on her way home. Her approach is sure to summon the hungriest, or possibly the greediest youngster to the entrance of the tree cavity. Thrusting her bill far down his gaping throat, she uses force enough to impale him. One confidently expects the point to appear somewhere through the baby's back. With the same staccato motion used when drumming on a tree, she jerks her bill up and down so violently that the fledgling has all he can possibly do to hold on during the second or two it takes to pump part of the contents of her stomach into his. Yet the next baby pushes and scrambles for position when the first one slips back satisfied, just as if he anticipated a truly delightful experience! By this same method-regurgitation-are humming-birds, purple finches, and many other birds fed, doubtless many more than we suppose, for it is only a few 


\section{How to Attract the Birds}

vears since the habits of so common a bird as the flicker were thoroughly studied. The vultures eject the contents of their stomachs at will, as we shall see in a later chapter, for quite a different purpose.

Fish-eating

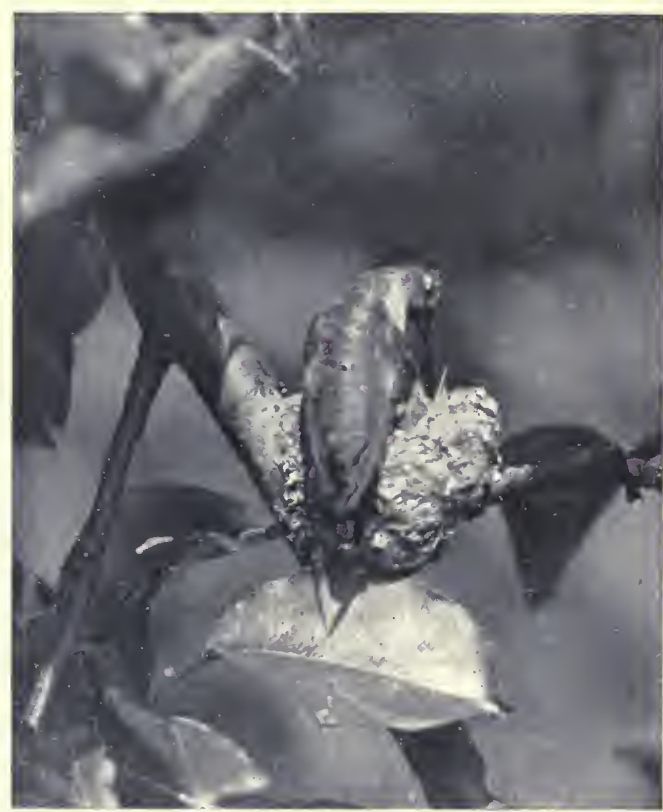

Humming-bird regurgitating frod into crop of her young birds especially are wont to regurgitate their food. While the cormorant is flying home with its babies" dinner safely stowed away, the fish's skin will be digested off completely, leaving the meat in prime condition for young stomachs. ()n the other hand, some fish eaters allow their ba-

bies to swallow skin, bones and all. The pelicans which ply the coast of Florida, searching for food, collect a quantity of fish in the great pouch which hangs from their lower bill like the silk bag which used to drop from beneath our grandmother's sewing tables. On returning to the nest, open flies the parent's bill displaying the fish. The eager, crowding babies are invited to thrust their heads into the 


\section{Home Life}

pouch and help themselves. And how they prod and poke about among the morning's catch, to make the best selection possible! It is a wonder the skinny pouch is not torn asunder by such thrusts and stabs as the ill-mannered little gourmands give it. No sooner is the family larder emptied, and the parent's back is turned to refill it, than the dissatisfied youngsters begin to squabble over the contents of one another's pouches. Their greed seems even more insatiable than their appetites.

The hawks, owls, ospreys and some other birds should make the best of stepmothers, so bountifilly do they provide for their nurseries. Mice, muskrats, eels, small fish, young rabbits, rats, woodcock and grouse, weighing over eighteen pounds in the aggregate, were the surplus food removed from the nest of a pair of horned owls, wherein two owlets only had to be supplied. Some birds of prey heap food about their offspring until they can scarcely see over the piles. Owls choose the brains only of most of their captives as food for their babies.

A remarkable provision is made for young pigeons during the first week of their lives. When the squabs thrust their bills into their parents' throats to be fed, there arises what is erroneously called "pigeon's milk" from the crops of both the father and the mother. This secretion, formed from the peeled lining of the parents' crop-a result following incubation-gradually becomes mixed with regurgitated food as the squabs grow older, and it ceases only when their digestion is strong elough to dispense with baby diet. Apparently this strange secretion is peculiar to the pigeon tribe. 


\section{How to Attract the Birds}

\section{LOWER AND UPPER CLASSES}

The labour involved in rearing a familv differs, of course, with the species by reason of physical conditions, temperament, and environment. Some birds of the lower orders have little required of them by Nature, while others, more highly organized,

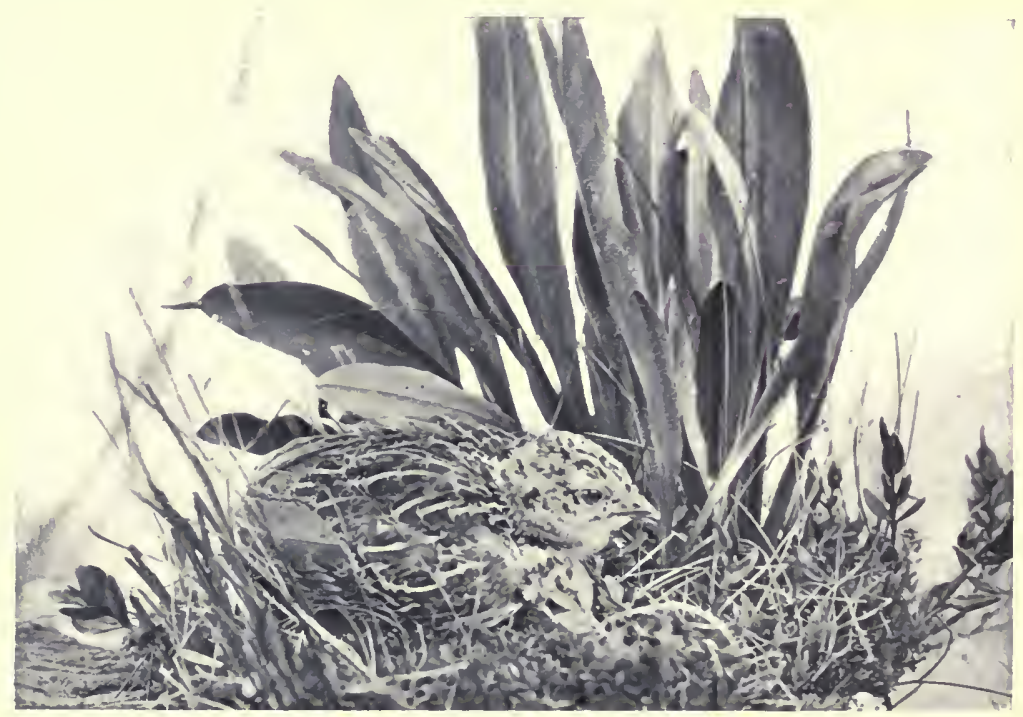

A precocial grouse chick

are enslaved by family cares as if they were afflicted with the New England conscience. But, generally speaking, there are only two classes: the lower or precocial birds, including those which, fully clothed and wide awake when hatched, are able to run or swim at once and pick up their own living like our domestic fowls, ducks, Bob Whites, grouse, plover and snipe; and the altricial birds-those which come into the world blind, naked and helpless, or nearly 


\section{Home Life}

so, like the heron, kingfisher, woodpecker, robin, and all our song birds. The precocial ruffed grouse develops from an egg that is large in proportion to the size of the mother's body, the heavy yolk nourishing the young bird during eighteen days of

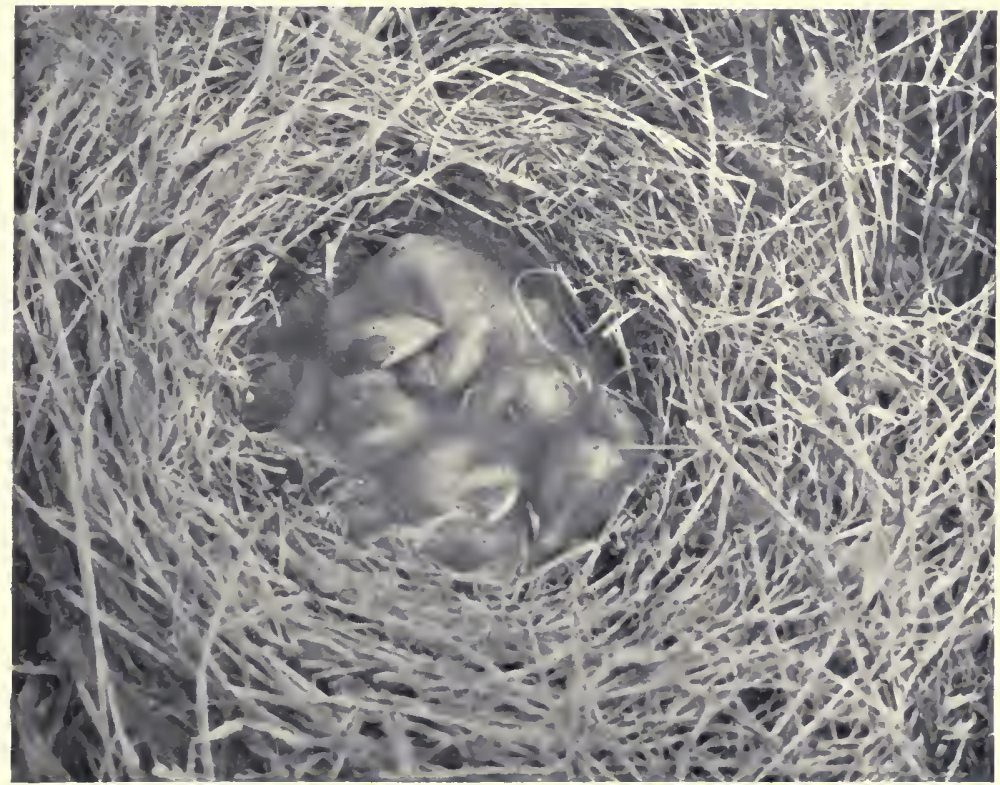

Blind, naked and helpless altricials. Young blue-birds

incubation and even after, whereas the altricial vireo lays a very small egg that hatches in one week. But even precocial and altricial birds of the same size in maturity may have come out of shells that differ as greatly as a silver dollar differs from a quarter. And the length of the period of incubation is in nearly, if not exact, ratio to the size of the egg. The largest bird's egg we know, the ostrich's, re- 


\section{How to Attract the Birds}

quires forty days, sometimes a full six weeks, to hatch. As in all arbitrary divisions, it is not always possible to draw a sharp dividing line. Between precocial and altricial birds, innumerable gradations occur.

Among the lower bird forms, polygamy being common, there can be no home life, and it is fortunate these chicks are independent little creatures from the first. Indeed, it was John Fiske who contributed to science the fact that the advancement of all creatures-not of the human race alone-has been measured by the prolongation of the period of infancy. The longer the young are dependent on both parents, the stronger the tie becomes between mates, the more prolonged and beautiful the home life with all its strengthening physical and moral influences making for the uplift of the species, until, among civilized humans, home living becomes a life habit, far outlasting the presence of children beneath the roof. Let the so-called advanced woman, with her unscientific notions of a readjustment of the partition of labor between the sexes, remember that the males among the ostrich tribe, most nearly related to the reptiles, take entire charge of the young. Certain plover fathers, too, and phalaropes attend to nursery duties, even to sitting on the eggs, leaving their wives free to waste their strength on clubs, pink teas, or whatever may be the equivalent among "advanced" feathered females. (On the other hand, the selfish, dandified drakes of some of our wild ducks desert their mates as soon as the first egg is laid, lest any domestic duties might be demanded of them; nor do they rejoin their families until the ducklings are educated and fully 


\section{Home Life}

able to Hy. By way of apology for such neglect it is said that a drake retires necessarily to shed his wedding garment, and that by the time the ducklings' education begins their father is apt to be so denuded of feathers as to be not only useless, but a positive drag on the family, since he cannot tly. In very rare instances could this be true. One has only to watch a hen care for her chicks to realize that even precocial birds need the guardianship of at least one parent. Devoted little Bob White, with a fidelity rare among precocials, is a model husband and father, volunteering to take entire charge of the family, while Mrs. White sits on the second set of eggs. When she leads forth the new brood to be educated in wood lore with their more advanced brothers and sisters, the bevy thenceforth enjovs an ideal family life. Roving through the grain fields, underbrush and stubble, the large family party keeps close together, especially at night when parents and chicks huddle into a compact group, tails toward the centre, one of the number always remaining on guard to warn the sleepers of approaching danger. Such prolonged devotion among the quail is the more beautiful in birds closely related to the polygamous, indifferent barn-yard rooster and to the turkey gobbler, from whom his mate runs away to hatch and rear her young lest they fall victims to their father's fits of jealous, murderous rage.

PROGRESS THROUGH HOME LIFE

The more that the home life of the birds means to them, the higher have they ascended in the evo- 
lutionary scale, the more pains they take to build a practical, beautiful nest, the more attached they become to it, to their mates and helpless young; so that if there were not a few prominent exceptions among precocial birds one might almost say that domestic virtues and true domestic bliss are monopolized by the altricials. However, among the latter it by no means follows that conjugal devotion necessarily extends beyond a single nesting season. Few birds, indeed, seem to enjoy the society of their mates the whole year through; and we have seen that degenerates, like the cowbird, occur in the most respectable, altricial families. Even the eagle, which mates for life, appears to care less for the partner of his joys and sorrows after the annual brood is carefully reared, than he does for his eyrie, just as his relative, the osprey or fish hawk, which also remains faithfully wedded to one mate till death parts them, appears to love nothing in the world quite so much as the great bundle of sticks, every year of greater bulk, which they build in some tree top near the shore. Indeed he thinks it no shame to snatch the fish from his wife's talons and eat it himself. To see a pair of loving little downy woodpeckers at work in turn excavating their hollow home, or the mother feeding their young while the father considerately goes in search of food for her when she is too tired to hunt for her own dinner, one might think that here, at least, was devotion enough to last a lifetime; but when the little woodpeckers have flown and winter nights are long and cold, it is Mr. Downy alone who occupies the sheltered cozy home in the tree trunk, leaving his 


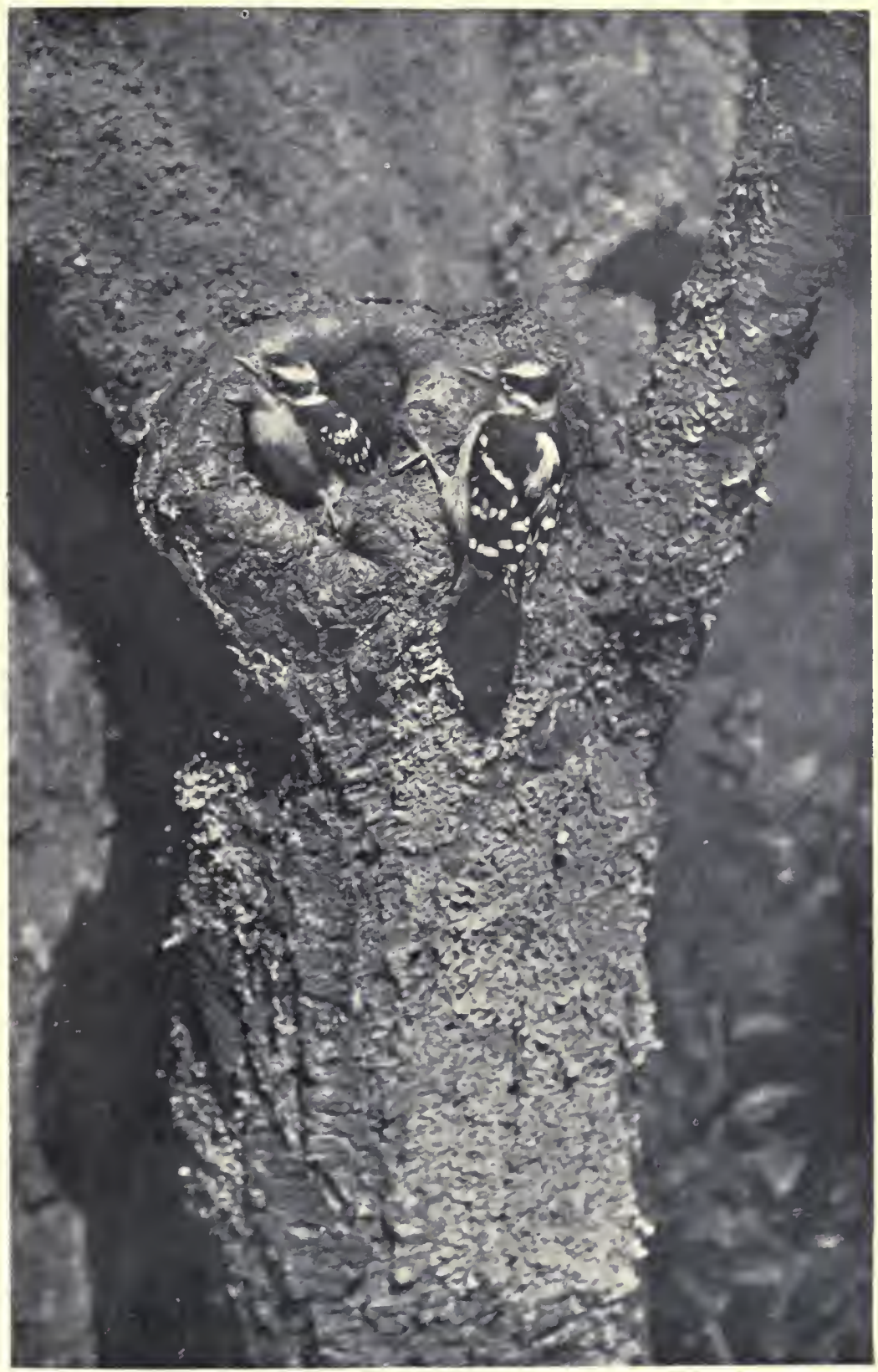

The home of a nair of downy woodpeckers 



\section{Home Life}

wife to excavate another shelter or shift for herself as best she may.

\section{"THEN, IF EVER, COME PERFECT DAYS"}

While it is true that manners improve steadily the higher birds ascend in the evolutionary scale; that hen-pecked husbands are treated with more consideration, overworked wives with greater respect and even tenderness until burdens become more evenly shared by both mates, and such refinements as song develop to express the highest emotions of which a bird is capable, nevertheless ideal devotion is short lived, confined as it is to the nesting season. Home life, worthy of the name, occupies but a fraction of the birds' year. After the young are reared, nests are usually deserted, and the old birds go off to moult and mope. When new feathers are grown, it is time for most of them to gather in flocks and prepare for the autumn migration to warmer climes.

But in June, home life in all its brief duty is at its height; now is the best time in all the year to really know the birds. And it is never necessary to look far before finding some happy, feathered neighbours; yet if you intrude upon their home life and frighten the parents away, another tragedy of the nest may be added to the long chapter. A young girl from the city who was thoughtless enough to wear a stuffed sea-gull on the front of her hat, stood on the piazza railing of a certain farmhouse to peep in the nest of a phoebe that had built under the eaves. With a piteous cry the startled little mother sprang from her nest, Huttered an instant, 


\section{How to Attract the Birds}

then dropped onto the piazza floor dead from fright. The conscience-stricken girl ripped that gull off her hat at once, but five cold little eggs followed it to

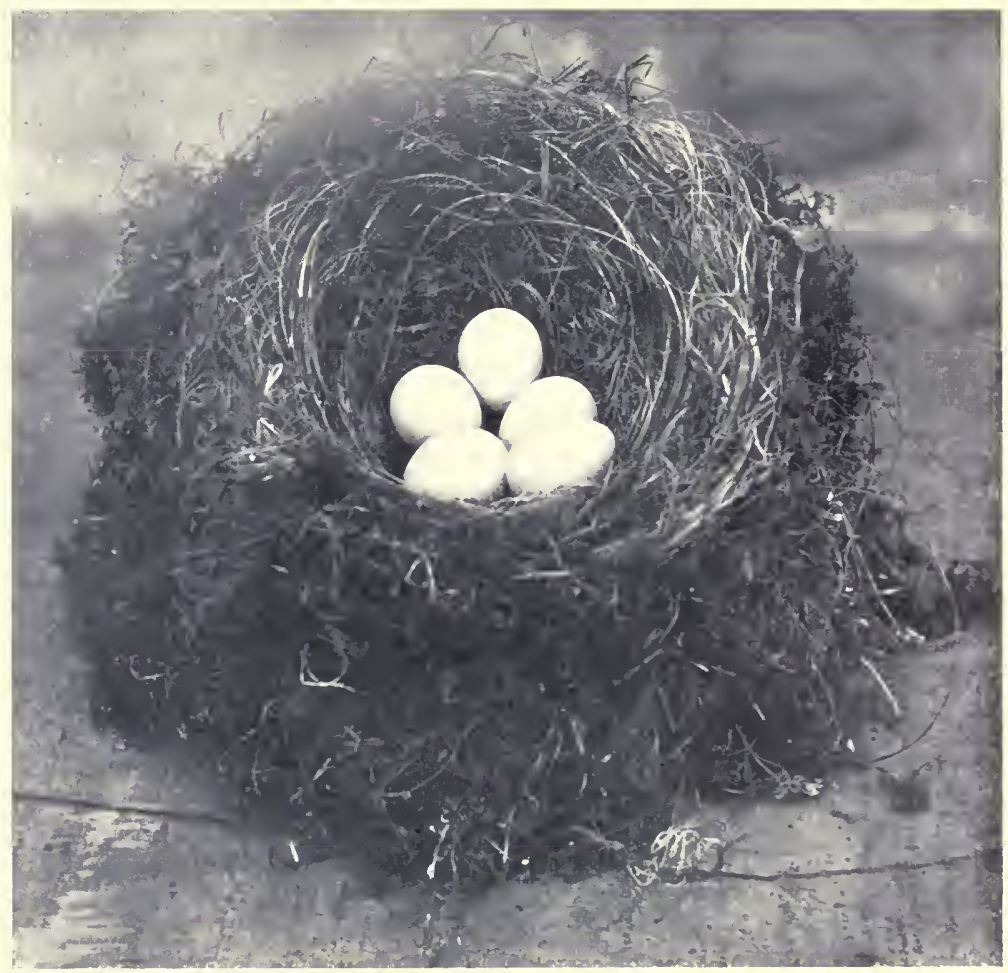

Five cold little eggs followed it to the ash barrel

the ash barrel the next day. Now she watches the birds from a distance through an opera glass.

\section{WHEN CHARACTER TELLS}

One might tell no end of stories to show how the birds, like human parents, fail or succeed in 


\section{Home Life}

training their young. Watch some over-indulgent little sparrow mother, harassed by the most spoiled of children as large as she and twice as greedy, which follow her about, drooping their wings to feign helplessness, teasing for food that they are perfectly able but too lazy to collect. Daring, aggressive, impertinent to others, the English sparrows are especially weak in the presence of their children. On the other hand, many birds are strict disciplinarians and do not hesitate to enforce their commands with a vigorous slap of the wing.

It is in his family relations that a bird's true character may be read most plainly. The kingbird, which usually shows only the pugnacious side of his disposition to the world, fearlessly dashing after the largest crow to drive him away from the sacred precincts of home, reserves his lovable traits for the family circle. No dragon-fly he captures on the wing is too choice to deny himself for the benefit of his babies, or too large, apparently, to be crammed down their throats. In June, neither the brilliant scarlet tanager nor the gorgeous Baltimore oriole hesitates to help his inconspicuous mate rear their brood for fear his tell-tale coat may invite destruction from the passing gunner. In June, fear and selfishness alike are overcome by love. If you will focus the opera glasses on the nest to which the oriole's rich, continuous song directed your suspicions a few weeks ago, you will see both father and mother feeding their noisy young at the rate of about twenty visits an hour.

A more charming sight than an oriole family feasting on basket worms among the green spray of 


\section{How to Attract the Birds}

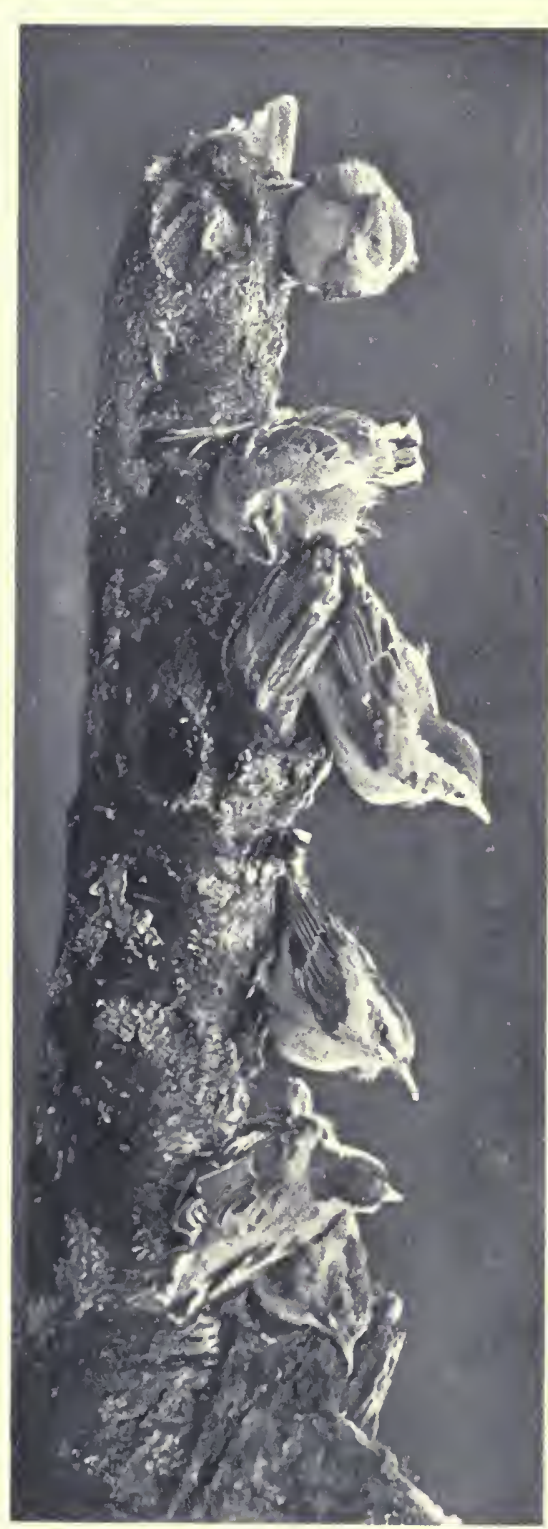

'The nuthatches' first acrobatic feats a tamarix bush would be hard to find, unless you happily discover a tiny humming-bird teaching her diminutive babies how to preen their feathers daintily with their needle-like bills. They are taught to attend to their toilet when they are scarcely larger than bumblebees.

It was the rattle of a male kingfisher informing his babies hidden within the bank of a woodland stream that he was bringing them fish for dinner, that first advertised his wellconcealed nursery. Through the long tunnel the absurdlooking, skinny little birds, following one another in Indian file, would run forward to greet him, then as quickly run backwards to receive the 


\section{Home Life}

fresh fish. Does any other bird possess this curious ability to run forward and backward like a reversible steam engine? Surely not unless it lives in a narrow tunnel.

The distracted oven-bird, feigning a broken wing as she crosses your path in the woods, invites pity or perhaps destruction, if only you will spare those speckled treasures which she thinks you know must be somewhere near although, but for her frantic performance, you might not have discovered the wellconcealed nest. Sir Christopher Wren, by the very exuberance of his bubbling, continuous song, betrays the precious secret that Jenny, by her excited scoldings, no better conceals. But the bobolink, swaying on a stalk of timothy in the meadow, and singing with rollicking abandon, is quite as clever as the ventrıloquial yellow-throat in luring you from his nest hidden in the grassy jungle. How jealously the true bird-lover likewise learns to guard nest secrets! The best children in the world can't be trusted with them.

Some boys in North Carolina robbed a crow's nest and kept the fledglings hung in a cage in their garden. The distracted parents visited the place hourly, brought food to their young and tried in vain to break open the wire prison. Finally, in despair, they dropped poisonous berries through the bars: it was evidently easier for them to see their babies dead than prisoners of the enemy. 

NATURE'S FIRST LAW 



\section{CHAPTER V}

\section{NATURE'S FIRST LAW}

Great was the astonishment of a lady seated beside an open window sewing one May morning to have a Baltimore oriole fly from its half-built nest in the elm tree on the lawn to her window, alight on the sill, timidly advance toward her workbasket on the window-seat, and, while she sat motionless, breathless, to see it tug at the end of some darning cotton and then dart through the window with the cutting trailing from its bill. It did not take the delighted hostess long to prepare more tempting invitations for her guest to return. Breaking off short lengths of worsteds, some bright coloured, some brownish gray natural wool, she spread them about on the casement. Presently the bird flew by the house again, caught sight of the worsteds, wheeled suddenly about, alighted on the shutter, hopped to the worsteds, selected a gray strand and flew off. Again the oriole returned; again she chose the natural wool. On the sixth trip her feminine taste was apparently sorely tempted by a bit of pink yarn, for she touched it twice with her bill before deliberately carrying away the last grayish piece. Every bright-colored strand was rejected. This set the lady thinking.

Of all our common birds, the oriole is perhaps the most asthetic. That she is far in advance of most of her kind is shown by her marvellous skill 


\section{How to Attract the Birds}

as a weaver, and further proved by the attractions in a mate that are necessary to woo her-the most gorgeous of orange and black feathers, and, as if they were not enough, the most persistent of delicious songs throughout the courtship. Certainly, a bird with so keen an appreciation of form, colour and music must have some excellent reason for

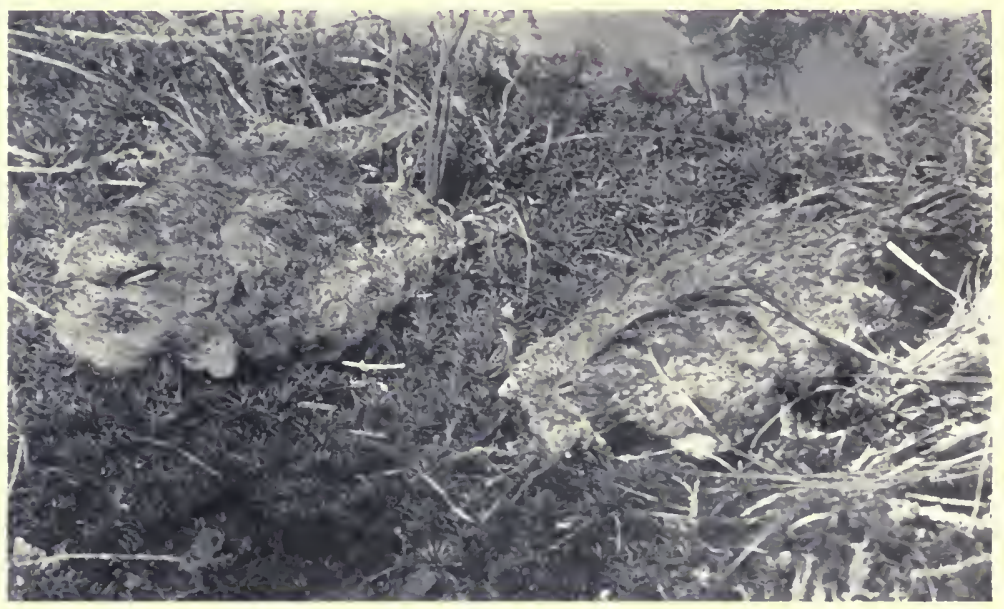

Young whippoorwills feel a sense of security from protective colouring

being so quietly clad and for choosing sombercoloured materials for her nest. The obvious reason explains also the motives of very many other birds respecting their plumage and homes.

A child less wise than Macaulay's schoolboy knows that various birds have adopted various methods of protecting themselves and their young, about whom they are even more concerned, every species having some special method of its own. By far the greatest number, however, depend chietly on 


\section{Nature's First Law}

the protective colouring of their plumage, and the more closely it harmonizes with their surroundings the more likely are they to escape the ever-watchful eyes of their foes. Naturally, it is the female which requires the greater protection, for, as we have just seen, it is she who builds the nest in the great majority of cases, covers the eggs and cares for the young, often with little help from her mate. His chief business in life is to woo and win her, therefore on him Nature lavishes her choicest gifts of plumage and song, even if she sometimes skimps on his beauty of character.

The oriole, more than any other of our brightly coloured birds, has learned to confide in man, living on terms of neighbourly intimacy with him; and, finding itself comparatively safe, it has lost the fears that once must have beset all conspicuous birds. Yet there is need for the mother oriole to reflec $\hat{\imath}$ in her feathers the olive green, soft grayish brown and yellow of the leaves, twigs and sunlight she lives among. She still swings her cradle from the tip of a high branch where small boys, cats, red squirrels and snakes fear to dangle, and, in regions where hawks are common, she makes the felt pouch deep enough to conceal her while she broods.

The mate of the brilliant scarlet tanager likewise mimics with her clothes the sunny green light of the tree tops. Except for the merest suspicion of blue in her plumage, one would never suspect the indigo bunting's dingy brown little mate of belonging to him. She, like her sparrow cousin of the dusty roadsides and dry fields, looks of the earth, earthy, while he, to win her, boldly dares to wear 


\section{How to Attract the Birds}

a deeper blue than heaven among the glistening verdigris tints of his coat. Nor are any telltale feathers worn by the wives of our most brilliant warblers, the blackburnian and the redstart, which must instantly arrest the dullest eye when they flash

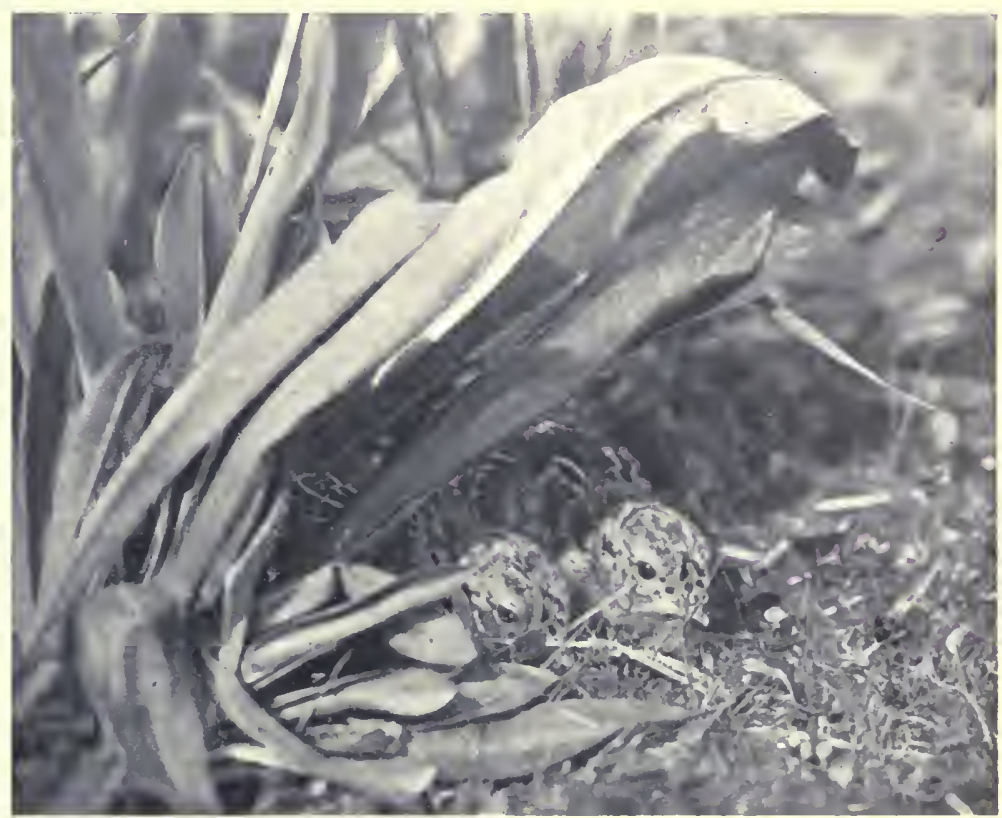

Young grouse confident they are hidden trom the camera man

glowing bits of flame and salmon among the deep shadows of their favourite evergreens. The robin merely wears a deeper red on his breast than his mate. Such accenting of colour at the nesting season in males that are otherwise similar to the females is common when neither bird has much to fear from brilliancy of hue. Male woodpeckers always wear more or less red on their heads, literally 


\section{Nature's First Law}

setting their caps for a bride. The English sparrow need attempt nothing more showy than a black cravat to impress his easily pleased sweetheart.

Young birds of either sex and of many species usually look like their mother when there is anything to be lost by following their father's shining example. In the latter case young males come into their splendid heritage of feathers by degrees, that they may be as inconspicuous as possible while learning the ways of this wicked world-probably not because their heads might be turned before maturity. Thus it takes the purple finch two years to perfect his raspberry colour, and during his youth he, too, looks sparrowy, betraying his kinship. Partly because the plumage of no group of birds is more admirably protective in their environment, the sparrows are inheriting the earth.

\section{WHAT BEAUTY COSTS}

Necessarily, every bird has the means to conceai or defend itself, or to escape from its natural foes; but when, after ages of natural selection, especially beautiful feathers developed on many, neither shotguns nor milliners 'had entered into the birds' calculations. How could the snowy white heron of the Gulf States have foreseen that the exquisite plumes (aigrettes) that he wears on his back as a wedding decoration would some day be transferred to the unthinking heads of vain women in such enormous numbers as to cause the extermination of his species? And on the face of it, would it not seem ridiculcas for any woman to wish to wear a 
How to Attract the Birds

stuffed parrot on her hat? Yet the Carolina parroquet, which was once common even as far north as

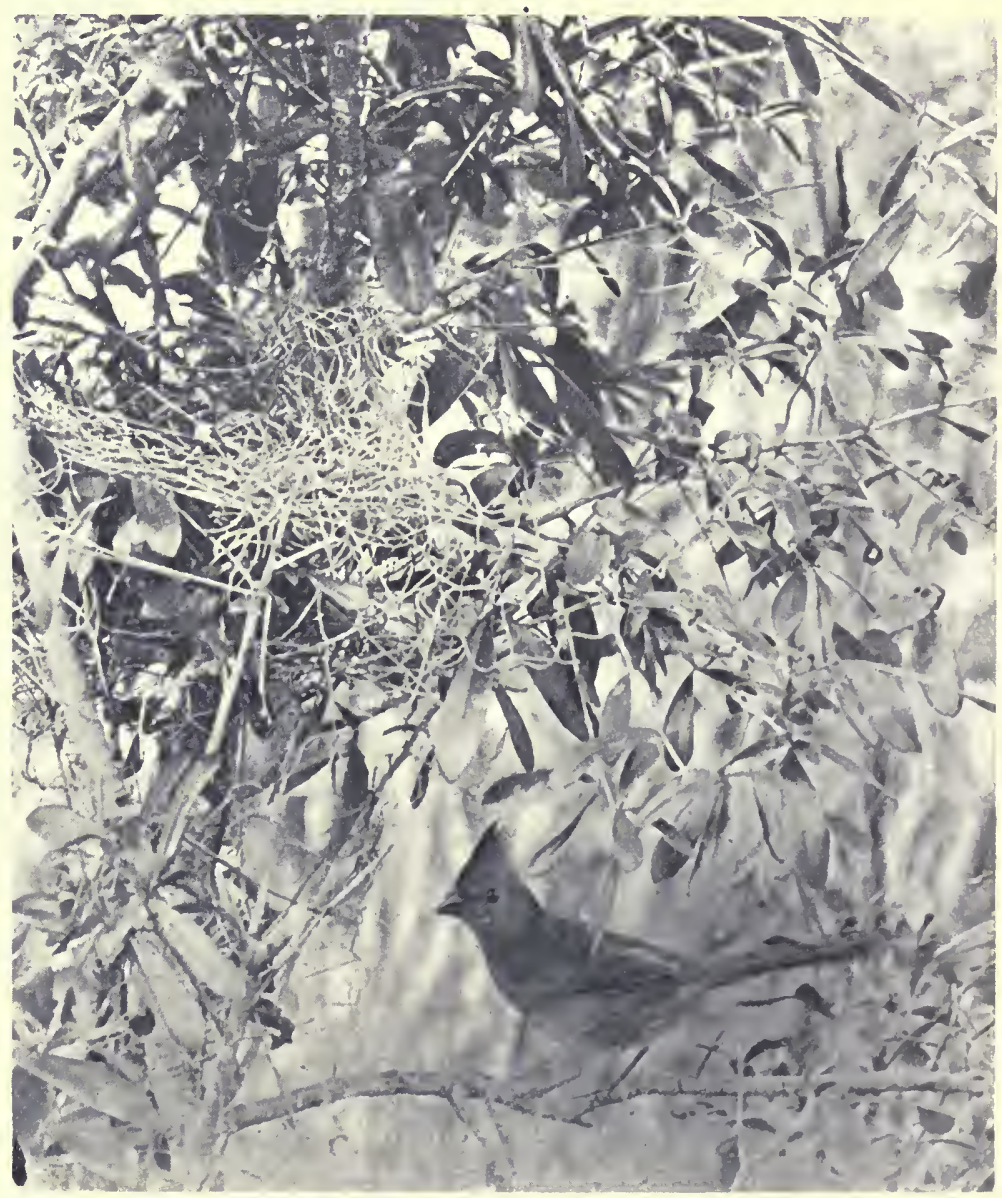

Letting his chivalry outweigh his prudence. Cardinal near nest

New Jersey, has been practically annihilated for no more worthy end. The wonder is that, in spite of a slaughter of the innocents repeated year after 


\section{Nature's First Law}

year, there should now be any birds left. But so rapidly has public sentiment in favour of protection developed, in the last decade especially, that there is already a perceptible increase in the numbers of birds around our homes. "The earnest expectation of the creature" has not waited wholly in vain "for the manifestation of the sons of God."

"No longer now the wingéd habitants

That in the woods their sweet lives sing away,

Flee from the form of man; but gather round

And preen their sunny feathers on the hands

Which little children stretch in friendly sport

Toward dreadless partners of their play.

. . . . . Happiness

And science dawn, though late, upon the earth."

We are wont to think of altruism as confined to the human species alone. Many conspicuously becutiful birds-even those brilliant targets for the gun and sling-shot, the Baltimore oriole, the scarlet tanager and the cardinal-risk their lives to carry dainties to brooding mates and help them rear the young. The rose-breasted grosbeak, frequently letting chivalry get the better of prudence, actually sits on the nest to relieve his plain little sparrowlike spouse.

\section{A CHANGE OF CLOTHES}

Fine feathers having been given many male birds for courting purposes only, why should not some of the hunted creatures seek protection in quiet clothes when the nesting season ends? Many do. All birds undergo at least one molt a year; those that put on a special wedding garment must molt twice. 


\section{How to Attract the Birds}

After family cares are over and our rollicking, tuneful bobolink has stopped singing - and he is the first to become silent-he changes his beautiful black, white and buff suit for a winter one of streaked brown like his mate's, because they will go South to live among the ripe brown grasses and sedges. In spite of Nature's kindly protective colouring, thousands of bobolinks (reedbirds, socalled) fall a prey to pot-hunters every autumn when the best beefsteak costs only twenty cents a pound, and it takes a dozen plucked reedbirds to make a handful!

Who that did not know him the year round would recognize the bright-yellow, black-winged little goldfinch of sunny pastures after he has exchanged his nuptial clothes for the drab-brown family dress? So cleverly does it match the colouring of weedy foraging grounds after frost, that one may pass a flock of goldfinches in late autumn without suspecting there is a bird in the field. Except for their waving flight one might mistake them for a flock of sparrows.

Arctic birds, like Arctic animals, turn white in winter so as to be scarcely detected in the snowy landscape. It is a poor rule that won't work both ways: white enemies are quite as likely to approach unseen as white prey is likely to escape. Occasionally a great snowy owl comes over the Canadian border, - a ghostly apparition among our birds. 'The ptarmigan, which lives above the timber line in our western mountains as well as at the far north, is white while the snow lasts, but by the time there are eggs and chicks to be covered the mottled 


\section{Nature's First Law}

gray, black and brown feathers, which have gradually taken the place of the white ones, may be

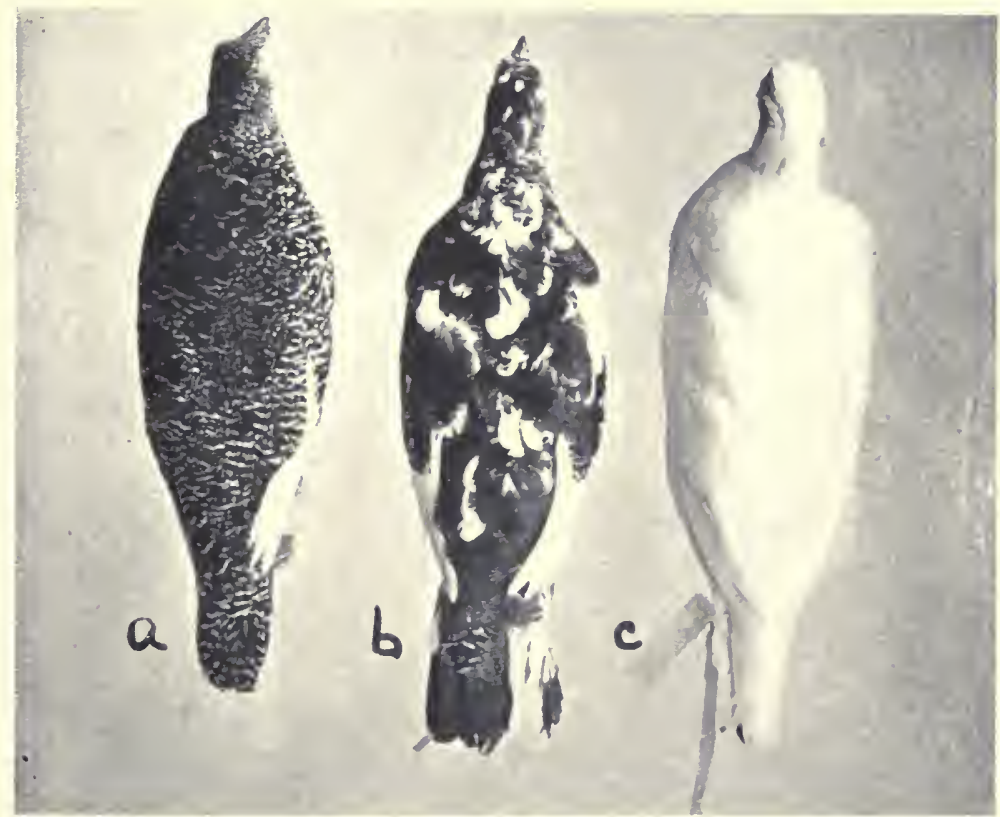

Seasonal plumages of ptarmigan

From specimens in the American Museum of Natural History

$a$, summer. $b$, postnuptial or autumn. c, winter.

scarcely distinguished from the soil and stones among which the hen broods.

\section{RELIANCE ON DECEPTION}

Feeling absolute confidence in the harmonious blending of their feathers with their natural surroundings, many birds keep perfectly still even in the actual presence of danger, thinking themselves overlooked, as, indeed, they are apt to be. Another 
advantage of deceptive colouring is that their prey often come unawares within striking distance. The bittern standing motionless in his marshy home, his neck stretched upward, looks far less like a bird when in this attitude than like a stump or snag among the bushes. But look out for his wing slap $a_{1} d$ thrust of the sharp beak if he thinks his clever deception has failed! A weapon intended to impale frogs makes an ugly wound on the human body.

It takes very sharp eyes indeed to tell bird from tree when the nighthawk flattens and stretches herself lengthwise along the log or horizontal limb, with whose mottled colouring her own blends so perfectly. Certain rocks match not only her plumage but her eggs too, which is why she often chooses a depression in such a rock to cradle them when a decayed stump or suitable site on the bare ground among dry leaves cannot be found. Indeed, the mottled eggs of both the nighthawk and the whippoorwill are as difficult to detect as any laid, although neither bird takes the trouble to build a nest.

Certain beach birds which lay their eggs among the sand and pebbles above high-water mark allow the sun to do most of the incubating while they ply the waters for food with an easy mind, feeling quite sure that the sharpest-eyed enemy cannot detect their treasures scattered among the shingle. Gulls and terns, which have favourite islands off our coast, return to them generation after generation to rear their families. Colonies of terns choose a nesting site on the mottled beach among rounded pebbles of the same size, shape and colour as their eggs, on which one may innocently tread, so perfectly are 


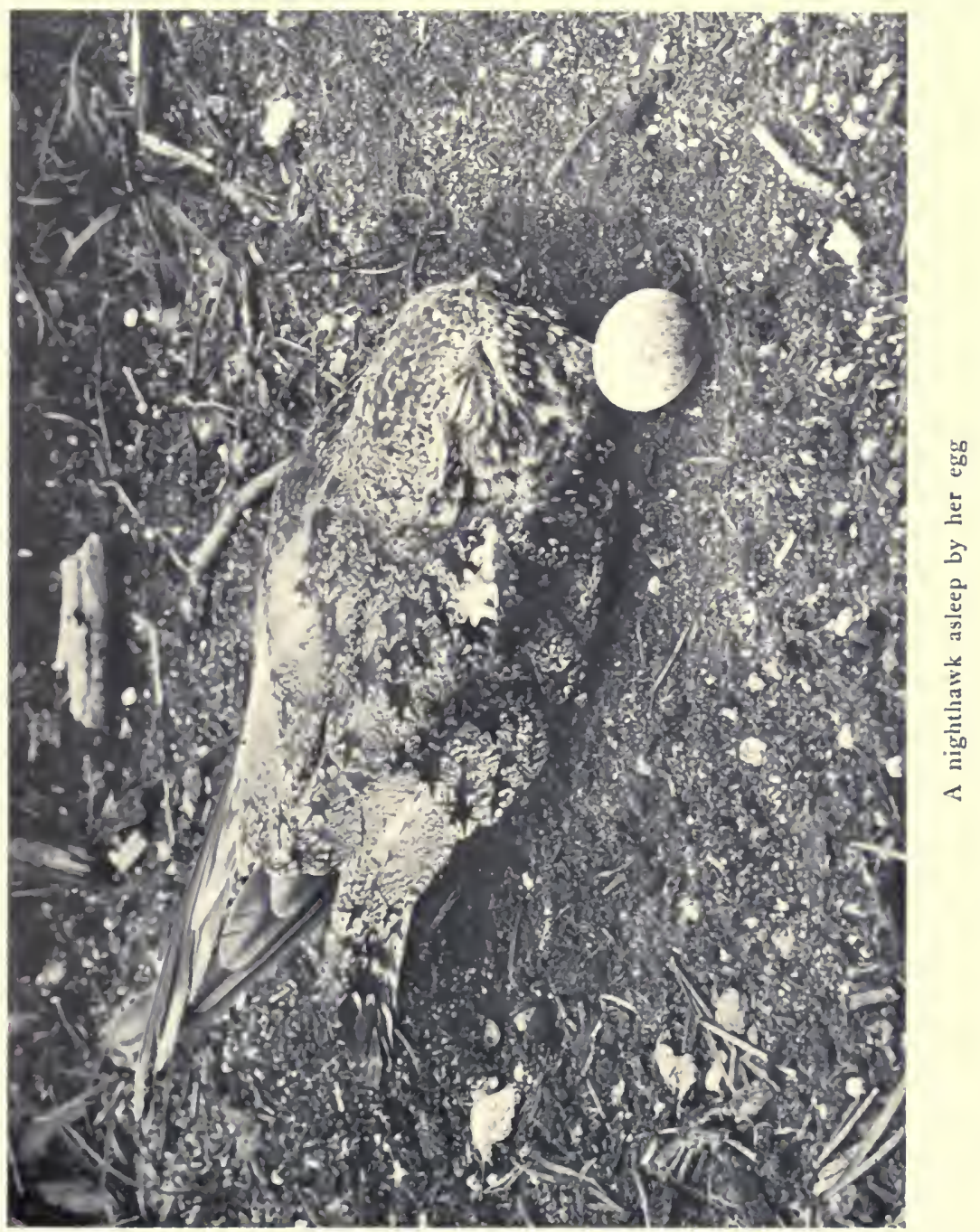





\section{Nature's First Law}

they concealed while yet completely exposed. Young terns, when running about the beach for food, stop short the instant danger threatens and keep still instinctively - their colouring usually affords all the protection necessary.

Every sportsman knows how wary the woodcock is, yet so confidently does the hen rely on the mimicry of plumage amid the dry leaves and fallen logs around her, that one can place a camera squarely in front of her ground nest and photograph her on it without causing her concern enough to wink an eyelid. There was no need for birds so protected to build in trees. Seated among last year's leaves, the brown ruffed grouse feels sure, as well she may, that you can scarcely distinguish her from them. When danger threatens her chicks, the youngest downy ball knows enough to stand or squat motionless, while the mother, by feigning lameness or a broken wing, tries to decoy you away. Standing even in the midst of a surprised covey of young grouse, who is clever enough to count them all?

\section{EVERY FEATHER MEANS SOMETHING}

The most casual observer must have noticed that many birds are dark above and lighter underneath, like the cuckoos, vireos, flycatchers, and sparrows, to mention only a few groups. Of what bird, indeed, is the reverse true? This colouring, of course, accords with a law of optics whereby dark upper parts receiving the most light appear no darker when seen from a distance than pale under parts which receive less direct light. The result, 
How to Attract the Birds

so far as birds are concerned, tends to uniformity and makes them inconspicuous. His great advantage

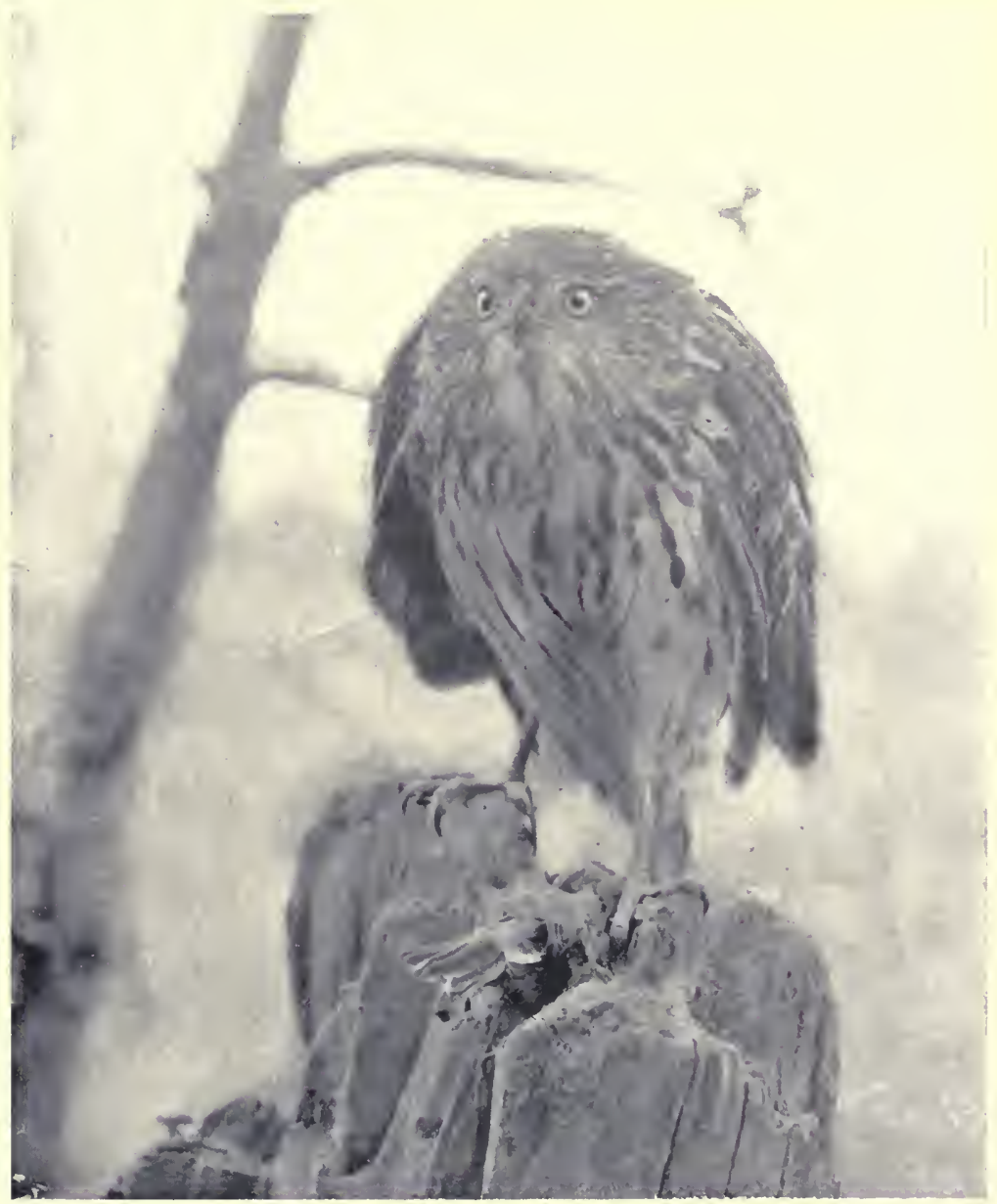

A foe of the air and its victim

in this respect is well known to the dusky kingbird, for he calmly sits unobserved on the fence rail or other point of vantage, waiting for an unsuspecting 106 


\section{Nature's First Law}

fly to sail by, when off he dashes, clicks his bill over his victim, and returns to the same lookout to watch for another.

As he flew off, you may have noticed the white band across the end of his tail. In common with many other birds that must migrate thousands of

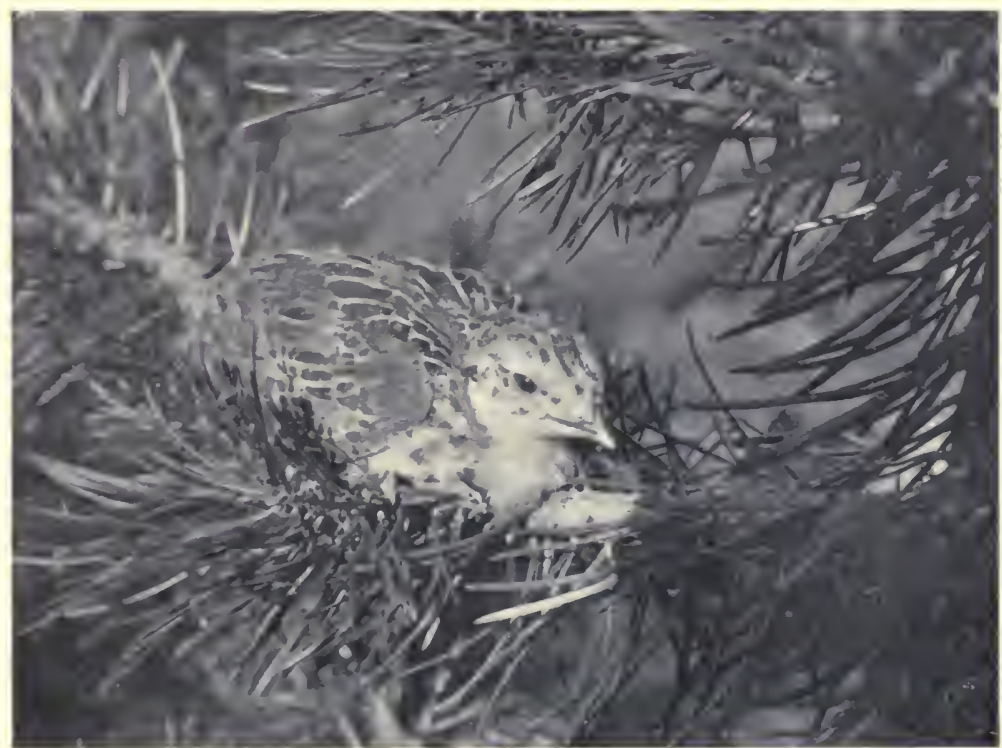

Young Richardson's grouse learnıng to perch above the reach of prowling enemies

miles every year, he shows the white feather, yet not to his enemies-for his pugnacity often amounts to tyranny-but to his friends that travel with him in flocks. Were it not for such showy white signals as the vesper sparrow likewise wears in his tail, the flicker on his lower back, and various other birds display on tail, back and wings, many a migrant 


\section{How to Attract the Birds}

would be lost, unable to follow the travellers just ahead through dusk or fog.

When he goes courting, the flicker takes ridiculous pains to show only his beauty marks in front to the well beloved. How silly feathered Benedicts are, too! Many a modestly attired little bird is as conscious of his charms at the wooing season, and displays them with as much pride, as if he were a peacock. In human beings, touch is the sense most acutely developed; in animals, smell; in birds, sight. Feathered lovers charmed the eye ages before they appealed to the ear.

\section{OTHER MEANS OF PROTECTION}

To insure themselves against being overtaken in a chase on land, some birds, like the ostrich, have developed extraordinary powers of running and kicking. The loon dives at the flash of a gun, several seconds before the shot reaches the place where he disappears into the lake. Chimney swifts and wild ducks, among others, travel on the wing faster than the fastest locomotive, and woe betide any weakly or maimed bird that straggles behind the flock, offering an invitation to dine that hawks are not slow to accept Indeed, the weak and sickly have little chance in Nature when ali laws converge toward perpetuating only the best there is in life. Beside their foes of the air-marauding hawks that swoop upon them by day, and stealthy, silent owls that snatch the dreamers from their perches-prowling animals from mice to foxes, and big and little snakes in the grass, are ever seeking whom they may devour. 


\section{Nature's First Law}

The unarmed turkey vultures or buzzards, so common in our Southern States, keep adversaries away by the foul trick of disgorging over them the contents of their carrionfilled stomachs. Roosters fight with spurs; eagles and hawks with beak and talons; geese and other birds still strike as effective a blow with their wings as did those which wore ivory spurs long ago. Even the tiny humming-bird is a desperate fighter and will longe his rapier-like bill at a rival like any duelist. The largest animal fears having his eyes put out by the pecks of the smallest bird. Why should the guilty crow fly away from the outraged kingbird's nest at his fastest speed if not that the big, powerful thief fears blindness from the stabs of the infuriated little

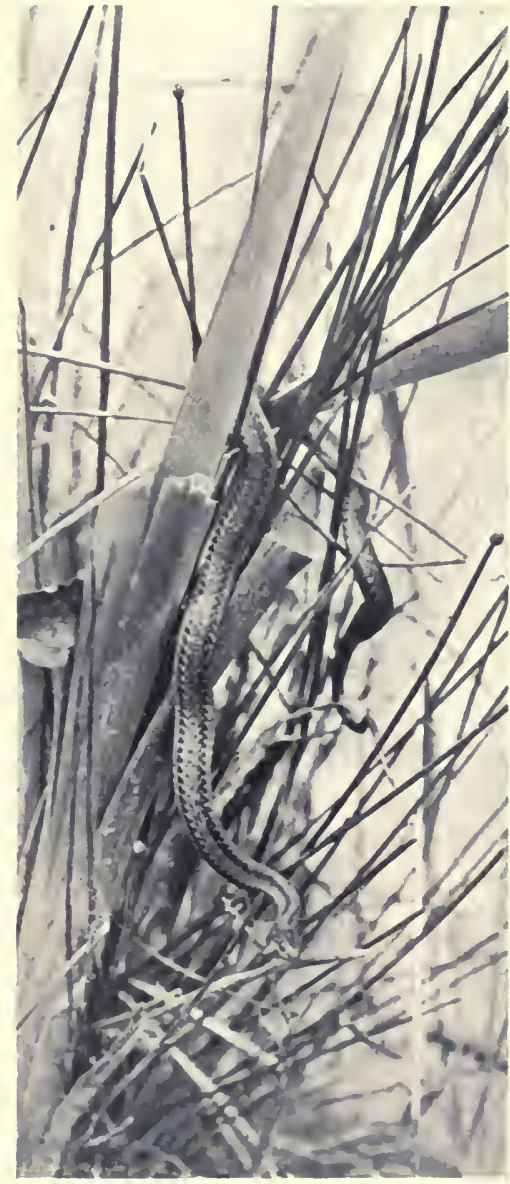

An egg-sucker. A foe of the ground parent dashing about his head in hot pursuit? No bird is so poor as to be without some method of self-defense. The tree of life in Nature, as in Eden, must be guarded. 


\section{How to Attract the Birds}

"ACCUSE NOT NATURE, SHE HATH DONE HER PART; DO THOU BUT THINE",

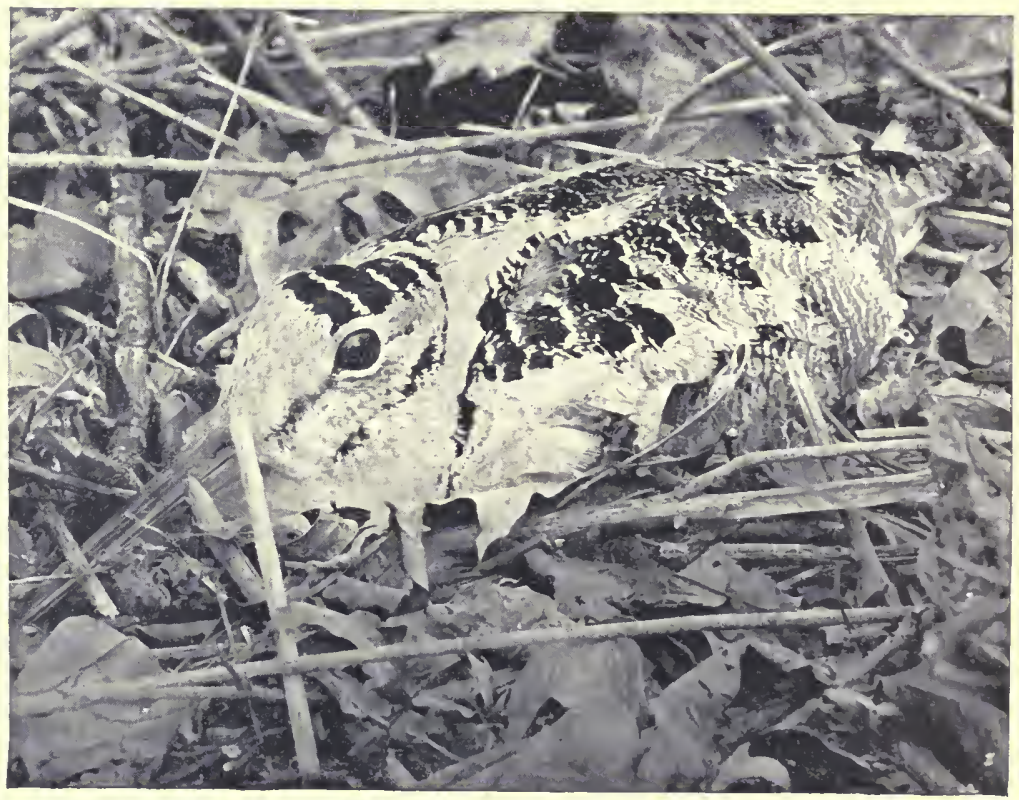

Woodcock on nest showing protective colouring. The beak is ever stuck under twigs and straws till it looks much like them

Certainly, birds banded together for mutual protection as instinctively as ever men did, yet through men have come the chief failures of their flocking habit. Enormous flocks of wild pigeons, consisting of millions of birds, so many that they darkened the sky, were a not uncommon sight in this land of liberty less than fifty years ago. But because pigeons nested in vast roosts, they were easily netted and slaughtered wholesale, until it is difficult to obtain a single pair of these exquisite birds for museum specimens to-day. Audubon found auks in numbers 


\section{Nature's First Law}

beyond computing around the gulf of St. Lawrence. But when a bird lays only one egg a year as the auk did, and when lawless men not only robbed a colony of all its eggs but clubbed thousands of old birds to death, extinction followed speedily. Far better for pigeons and auks had they scattered themselves over a wide area and had pairs nested apart. Better, too, for their race, if instead of prolonged grief over a lost mate they had followed the example of the happy-go-lucky English sparrows.

A pair of these prolific little pests began to build in the shutter of a New Jersey country house. The ornithologist who lived there shot the male, but in less than an hour the widow returned triumphantly with his successor. He likewise was promptly killed, and so was the third mate and the fourth, and so on and on until sixty cheerful volunteers had been ensnared to their death through the charms of the equally cheerful widow. Of course, the ornithologist claims that he did this execution purely in the interests of science! 

SONGS WITHOUT WORDS 



\section{CHAPTER VI}

\section{SONGS WITHOUT WORDS}

Anatomy shows us that the lower larynx, the syrinx or voice organ of singing birds, is the most marvelous musical instrument known, not excepting the prima donna's throat; that this organ, which is of the simplest form in birds of the lower orders, became more and more intricately complex the more highly birds developed, for song is of comparatively late achievement in their evolution; that the music which enchants us comes from where the bronchial tubes fork into the upper lungs; that a modulating apparatus, consisting of various kinds and numbers of bony half rings and muscles around the tubes and differing greatly with the different species, have much to do with a bird's scientific classification; that, by the automatic working of these muscles, musical messages of changeable tone and increased or diminished volume of sound may be sent at will through the tracheal sounding pipe - all this and vastly more that is anatomical might be told; and yet a deaf person, who has never heard a bird sing, could form absolutely no idea of its music.

"You cannot with a scalpel find the poet's soul, Nor yet the wild bird's song."

Or, let the technical musician, whose trained ear catches the most delicate gradations of tone, attempt to write down, for example, the little house wren's 



\section{CHAPTER VI}

\section{SONGS WITHOUT WORDS}

Anatomy shows us that the lower larynx, the syrinx or voice organ of singing birds, is the most marvelous musical instrument known, not excepting the prima donna's throat; that this organ, which is of the simplest form in birds of the lower orders, became more and more intricately complex the more highly birds developed, for song is of comparatively late achievement in their evolution; that the music which enchants us comes from where the bronchial tubes fork into the upper lungs; that a modulating apparatus, consisting of various kinds and numbers of bony half rings and muscles around the tubes and differing greatly with the different species, have much to do with a bird's scientific classification; that, by the automatic working of these muscles, musical messages of changeable tone and increased or diminished volume of sound may be sent at will through the tracheal sounding pipe - all this and vastly more that is anatomical might be told; and yet a deaf person, who has never heard a bird sing, could form absolutely no idea of its music.

"You cannot with a scalpel find the poet's soul, Nor yet the wild bird's song."

Or, let the technical musician, whose trained ear catches the most delicate gradations of tone, attempt to write down, for example, the little house wren's 


\section{How to Attract the Birds}

gushing lyric. Again, impossible! Just as there are intervals in the African negro's melodies too subtle to be recorded on paper, although they are caught by the ear of each generation from its predecessor and passed on correctly to posterity, so there is an elusive quality in bird music defying both scientific analysis and translation into set musical terms. As well try to convey music itself through a dictionary's definitions of it as to catch the rollicking, bubbling song of the bobolink on a printed page.

Many beginners in bird study write to the ornithologist, asking him to name the songster whose music is laboriously described on an enclosed sheet. Staff, added lines, clef, time, bars, notes, sharps, flats, naturals, rests, accents - all are as carefully set down as if the inquirer were copying an intricate Bach fugue; yet not once out of ten times can the bird be named correctly by its written song alone, no matter how well up in field practice the ornithologist may be: the quality is lacking, and that is the very essence of the song. Lacking that, some description of size, plumage, or habit must be mentioned to aid identification.

\section{CALL THE BIRDS TO YOU}

But catching bird music by ear is a different matter from writing it. Every farmer's boy knows that by crowing like his pet rooster he can make him reply, and that first one cock, then another, will echo the challenge, until every rooster in the neighborhood is set to flapping his wings and crow- 


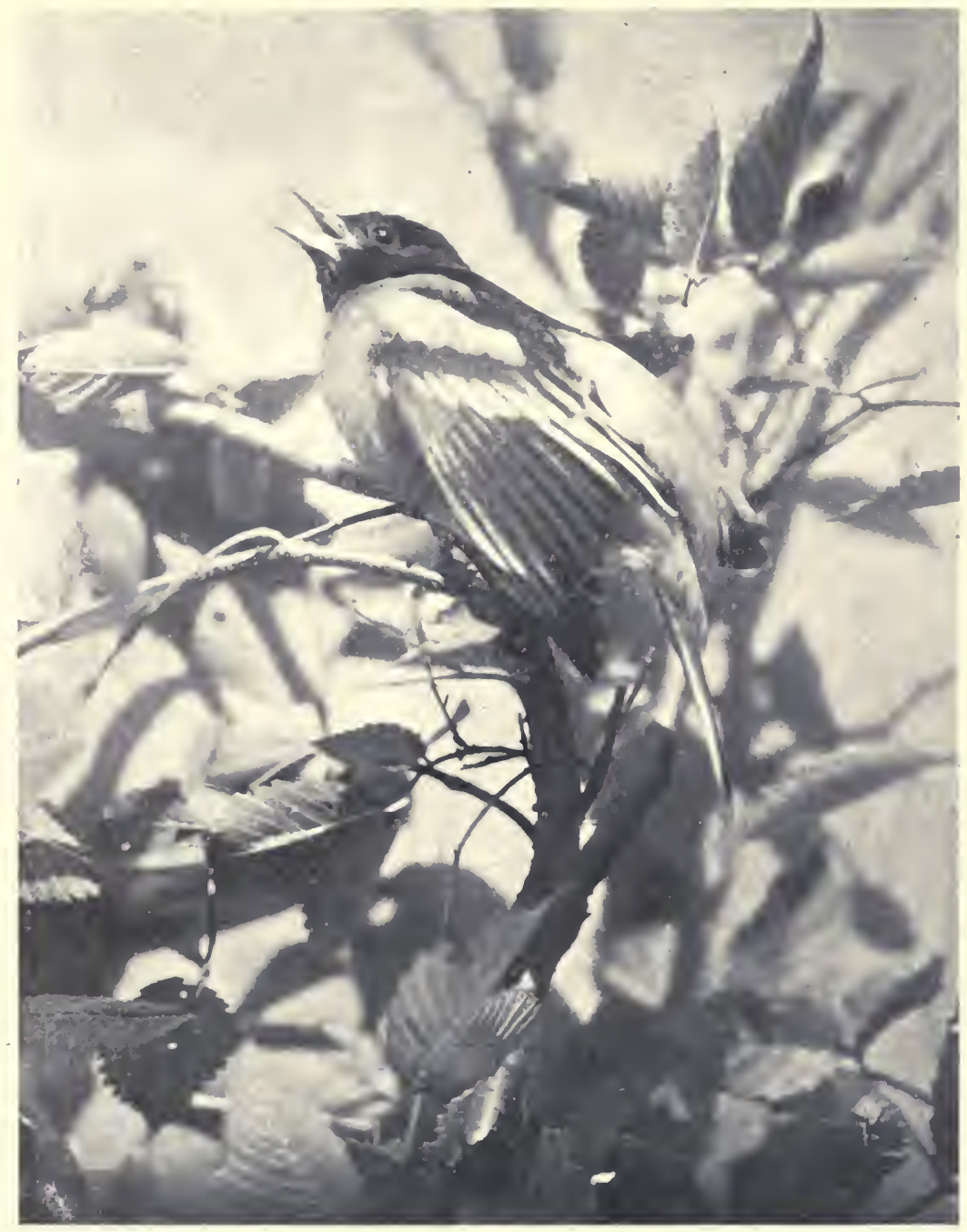

A gorgeous minstrel - the Baltimore oriole 



\section{Songs Without Words}

ing with all his might. Certain wild birds have simple songs so pure of tone, or so slowly delivered, or so sharply accented, that the merest novice who can whistle has little difficulty in imitating them well enough to deceive even the feathered singer himself into thinking that one of his kind is replying from the wood. One can "whistle up" silent birds, too, trying first one call, then another, to learn what bird is within hail; then, hearing a reply in the far distance, bring the minstrel nearer and nearer to investigate the freaky song - so like his own and yet so different!-that curiosity must be satisfied by closer inspection, until he frequently gets near enough to photograph, if not to touch. No birds

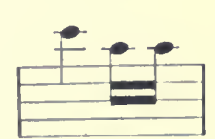
are more readily attracted than the friendly little chickadees, whose three very high, clear call-notes, once heard, are easily imitated.

The quail on the outskirts of the farm calls back a a cheerful "bob-white" to your sharp staccato whistle, and quite as promptly as if you were a sentry demanding "Who goes there?" Timid plover hiding in the grain fields utter a plaintive, almost petulant kill-dee, kill-dee to one who can call them by name. The phœbe bird, building under the roadside bridge or the rafters of your piazza, keeps up a monotonous pewit phrebe, pervit phabe whether you ask his name or not, although even he likes to hear it called. His relative, the wood pewee, whose song in B-flat minor suggests a rather melancholy religieux living apart from this wicked world, is quite ready to repeat his "one sweetly solemn thought," which "comes to him o'er and o'er"- at your suggestion. Indeed, 


\section{How to Attract the Birds}

nothing seems to daunt this pensive minstrel. When midsummer silences nearly every other voice he still sings on, with the indigo bunting and the red-eyed vireo. How refreshing is the song sparrow's cheerful, merry, but alas! inimitable, outburst after the solemn pewee! But one soon learns that the bird music which really enchants us - the bobolink's, cardinal's, thrush's or mocking - bird's, for example, - can never be imitated by human lips, albeit birds and humans are the only creatures that can sing. Andrew Carnegie said he would as lief shoot an angel as a song-bird, for bots must be akin because they sing and fly.

While a good whistler obtains satisiactory zesults by repeating after the birds certain of the sinpler songs until they are learned perfectly, it is quite a different matter to so record them on paper that one who had never heard them before could whistle them off, like ordinary tunes from a book, well enough to deceive the feathered songsters themselves. I doubt if it could be done. Take, for instance, the white-throated sparrow's familiar, welldefined strain. When this comes to be set down in cold type, no two books in the library record it

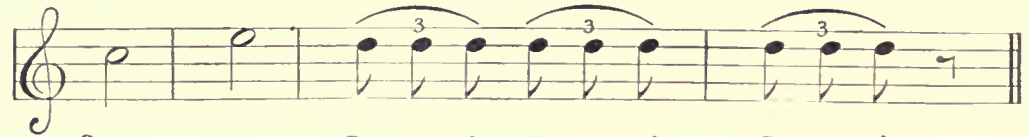

$$
\begin{aligned}
& \text { Swee...eet Can-a-da, Can-a-da, Can-a-da, } \\
& \text { I, I, Pea-bod-y, Pea-bod-y, Pea-bod-y. }
\end{aligned}
$$

alike. New Englanders think the bird devotes his vocal energies to glorifying "Old Sam Peabody," while our British cousins, over the border, are so certain that he sings the praises of their land they 


\section{Songs Without Words}

actually call him the Canada sparrow. "What's in a name?" All sorts of phrases, in words of three syllables, have been fitted to this strain in various sections, yet however differently people record the song, it is perhaps the only one written - the one out of every ten submitted-by which the persecuted ornithologist could correctly name the bird without further description. The sets of triplicate notes identify it, not the words which imagination supplies. But print can convey no idea of the exquisite quality of that high-pitched, piercing, sweet, tenderly plaintive strain. Whistle it from memory, in the cool of a spring day, in some deep northern forest-perhaps not one, but a half a dozen whitethroats will pierce the evening stillness, complimenting your poor performances as no opera singer yet was encored.

\section{HOW BIRDS LEARN TO SING}

It is nature's only way to teach sound-by earand still the most exact. As a child is born a certain racial type of linguist and learns to speak by imitating the words in daily use about him, so a bird enters life the kind of singer that he is and learns his notes by imitating those of his closest associates. Only, the more clever young child, given an equal opportunity to hear two languages, acquires one as readily as the other; while the bird, in a state of nature, usually confines its notes to the traditional ones of its clan, although it may hear the notes of scores of other species every day of its youth. Certain very young European goldfinches, isolated from 
others of their kind, showed a decided tendency to repeat only the notes of the caged songsters about them; still, they used some inherited notes, too, and these, with the inherited quality of voice, made their song sufficiently characteristic of the species to be recognizable. Many more experiments are necessary, however, to prove with scientific accuracy that a bird even partially inherits his song. We know that expert trainers have taught the bullfinch to whistle "Yankee Doodle." The mocking-bird is by no means the only mimic. A certain pet canary could so perfectly imitate the English sparrows that came about his cage on the porch to pick up the waste seed, that it was only by watching the movements of the feathers on his throat that one could believe it was he who was amusing himself by imitating the chirpings and twitterings of an entire sparrow flock.

Probably a bird both inherits and acquires his notes; otherwise, how could we account for the many variations of the same song rendered by different birds of the same species? No two canaries in any shop sing precisely alike, although all may have been hatched in the same peasant's house in the Hartz Mountains. In every case individuality reveals itself in shrillness or mellowness of tone, in the low, sweet, tender warble, or the sharp, almost vindictive roundelay incessantly repeated with the evident desire to overpower all rivals; yet we recognize the canary in each song. To the general characteristics of the species we must add individuality of temperament and the training received from the individual's associates before we can understand any bird's music. 


\section{Songs Without Words}

Travelers in the Canary Islands say that the wild canaries there are by no means so skilled musicians as the caged singers. Doubtless the bird's voice has been improved by cultivation as much as his feathers, which, originally, were greenish gray and brown,

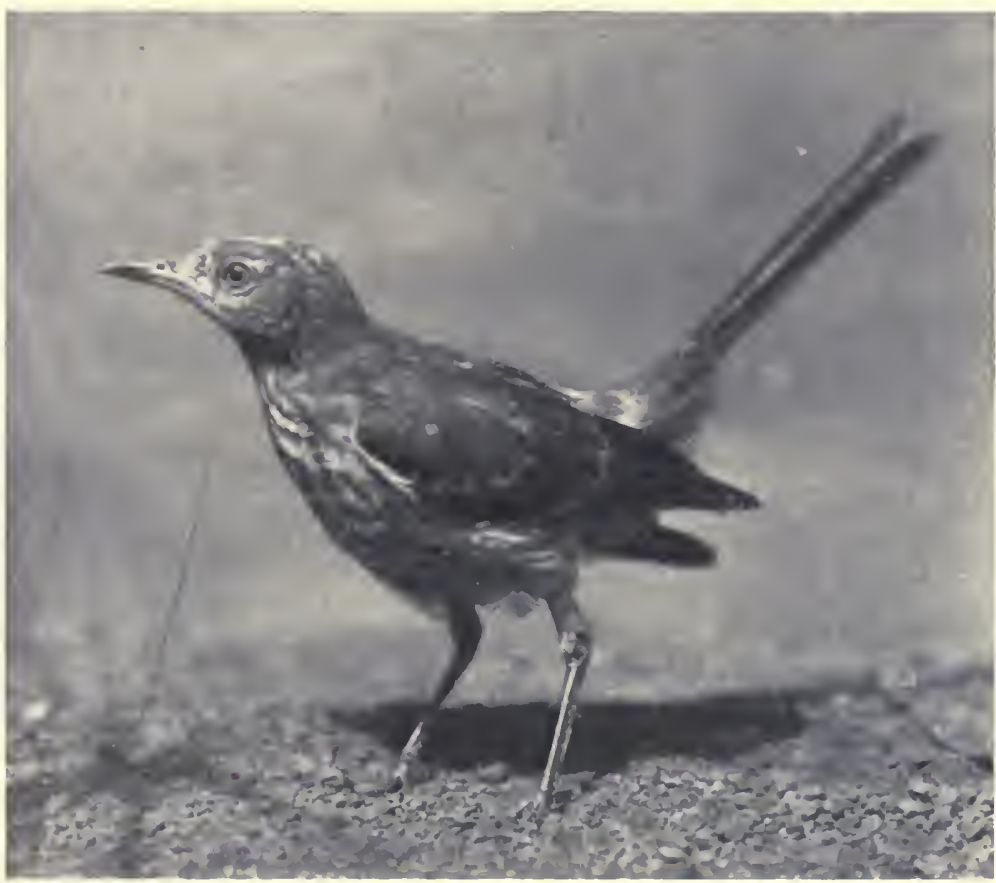

The chief American songster-a young Mocking-bird

when canaries were first imported into Europe in the sixteenth century. Nevertheless, our own wild songsters show almost, if not quite, as much diversity as the caged canaries when we concentrate our study on the music of a single species.

How many people who have spent their lives in the country recognize all the songs and calls even of 
the robin? Probably he is the first bird we learned to know by name. Among the first arrivals and the latest stayers, he lives on terms of neighborly intimacy with us at least two-thirds of every year; yet the fact that twenty-five distinct songs and calls have been recorded of a single individual by one who took no pains to study robin music in different sections of the country-where bird voices differ as greatly as human dialects-causes many people to lift their eyebrows with an incredulous "Is it possible?"

How his first salute to spring electrifies us with good cheer! The hair-sparrow's wiry little trill has scarcely roused the sleeping choir at dawn when he begins a subdued warble, which gradually increases with the morning light until, his throat attuned and all his powers fully alert, he bursts at last into the splendid exuberant performances which so delight us. Everybody knows it. Heard at its best, none is more exhilarating and few are more beautiful, but even his own meditative, tender, warbled even-song excels the matins. Then there are two less familiar strains given before and after rain, First call for break fast the exquisite love song without words yet perfectly understood, a call of caution to his mate, a clear, vigorous, ringing, military alarm, a signal to take wing, a summons to his comrades when they have gathered in an autumn flock, a self-conscious brag, an outburst of temper, endear- 
ing, coaxing notes for the young, scoldings for the cat, and so on through the gamut of his experiences. There appears to be a different vocal expression for each. And he has an old trick of humming to himself with his mouth closed, as if practicing for public recitals, - the most humorous performance of all, if you have the good fortune to surprise him at it.

\section{WHY BIRDS SING}

A study of farmyard poultry reveals a surprising number of call-notes in common use among chicks, hens and roosters, not to mention the ejaculations reserved for such unusual occurrences as the sudden swoop of a hawk or the headsman's axe. Forty distinct utterances do not exhaust their vocabulary. Here, better than elsewhere, we may observe the necessity for every call-note and its fitness, and apply some of our knowledge to the less accessible songbirds.

But a call is quite different from a song, and was doubtless evolved ages before it. One is a first necessity, the other a highly desirable but secondary acquisition generally attained only by the male. For the same reason that a rooster crowsto challenge his rivals or to make a favorable impression on the hens of his acquaintance-does a bird sing, and the more refined and beautiful his voice the higher does he rank in the books. Bird music means vastly more than a crow, gobble, boom, or drumming. It indicates the triumph of the higher nature over the lower; it may become the 


\section{How to Attract the Birds}

expression of those qualities which we usually associate with soul. "No original water-haunter or ground-builder ever sang," says James Newton Baskett. "Every melody is a march-a command to move onward - to the ear that can truly comprehend it."

\section{INSTRUMENTAL PERFORMERS}

For the sake of advertising their location as well as to please, some birds that can't sing resort to curious expedients. The prairie-cock inflates two loose yellow sacs on the sides of his head that stand out like small oranges. From these he lets out air to produce a booming sound,-powerful, penetrating like the deep tones of an organ,-which he repeats again and again until the whole neighborhood reëchoes and all rival cocks have been challenged to boom more loudly than he. Then all assemble, to fight with beak and claws, on their favorite "scratching ground," in the presence of an admiring circle of hens. The prize-fight among birds indicates no higher plane of development than among humans. We don't expect much of gallinaceous fowls.

Another of these, the ruffed grouse, usually mounts a fallen log, preferably one that has served many seasons as a drumming and trysting place. At first slowly beating his wings, he moves faster and faster, until there is only a blur where the wings vibrate too rapidly for human sight to follow. Without touching the $\log$ with his wings, striking only the air, he beats a rolling tattoo, a deep, muf- 


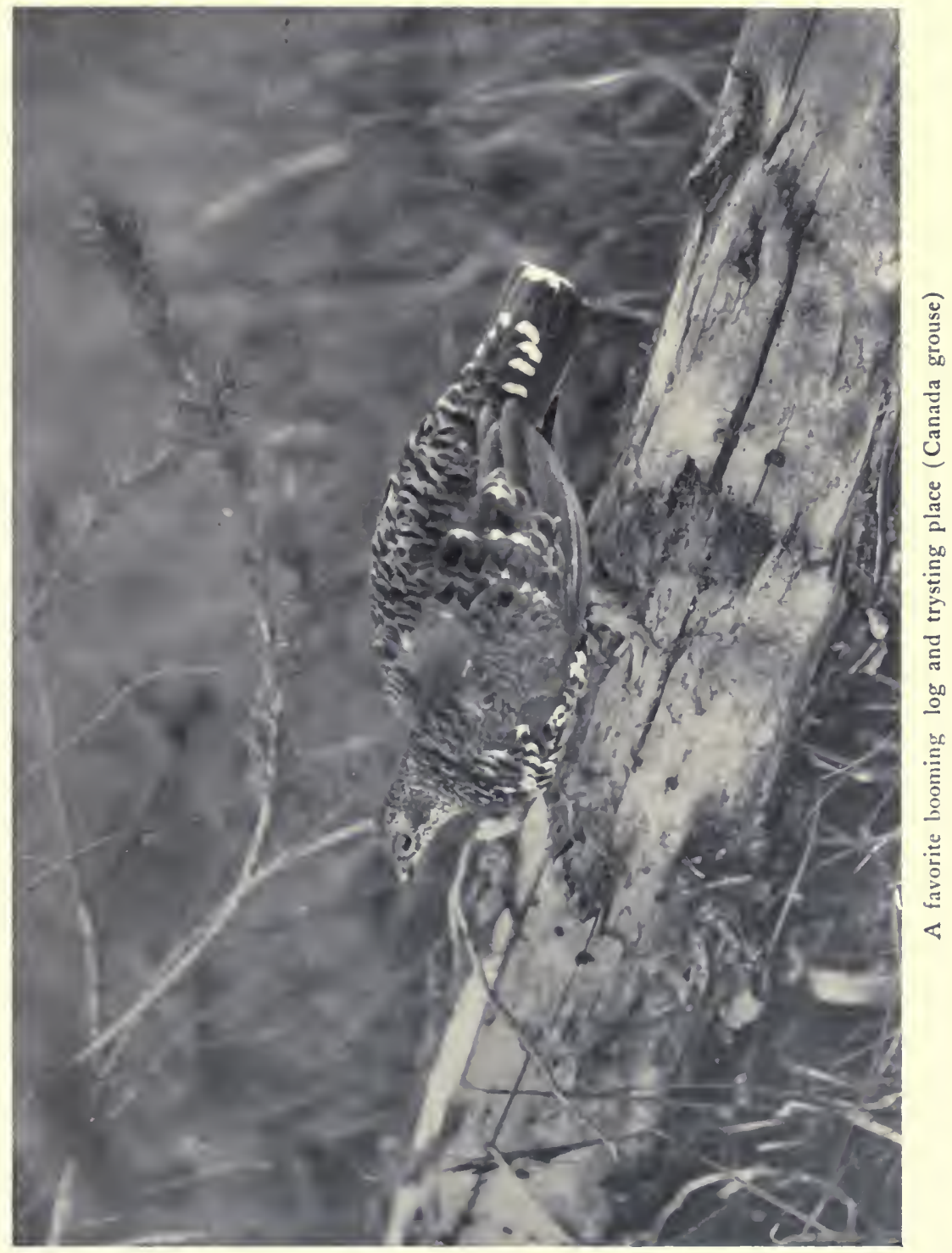





\section{Songs Without Words}

fled, sonorous, crepitating whir-r-r-r that serves as advertisement, challenge, love song, and an outlet to his inordinate vanity and vigorous animal spirits. Every sportsman knows that sound of the drummer without a drum.

When the nighthawk drops downward from a great height, his outstretched wings and tail create an æolian instrument which gives forth the jarring, booming, whirring noise that is more weird than musical.

With the exception of the flicker - a law unto himself among his clan-our native woodpeckers are instrumental performers only. The rap-tap-tapping of their bills against

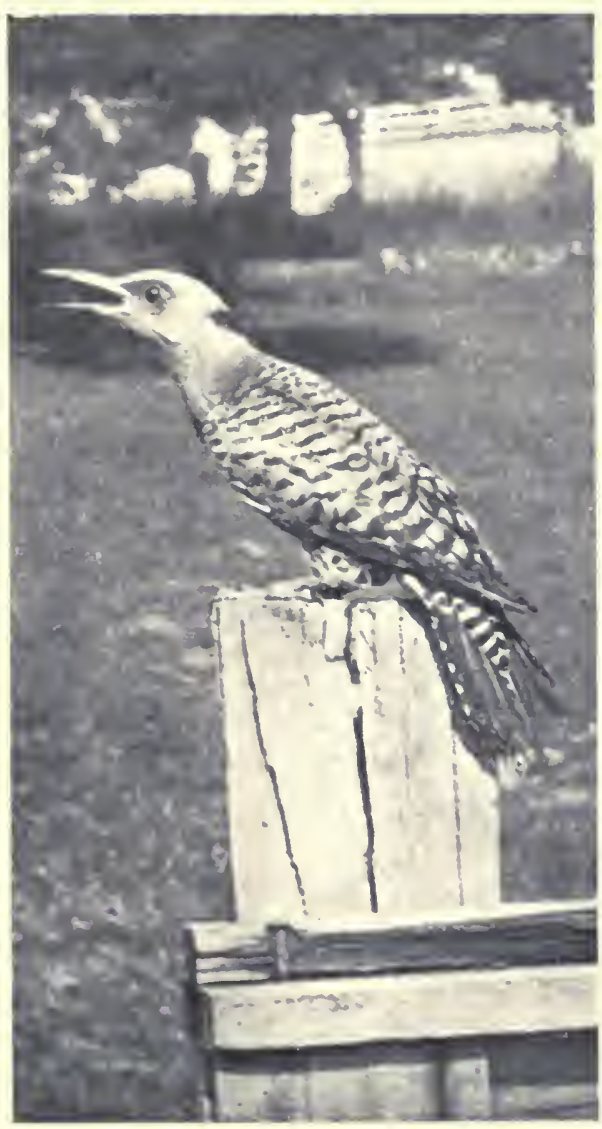

The Aicker - our only woodpecker vocalist the tree trunks is as cheerful music as any in the spring woods. The sapsucker hammers his vigorous, impetuous, staccato proposal with more sense of musical values, perhaps, than the others; but all are 
musicians, though they can't sing a note. Songless birds have found various ways of expressing their sentiments. Some dance, some ogle, and none is more ridiculous in his antics to woo the wellbeloved than the flicker, whose vocal accomplishments are by no means to be despised. All the woodpeckers delight in sound, however produced. Hairy and Downy frequently tap on the tin roofs and gutters of our houses simply because they like the noise. A pair of red-headed woodpeckers reared their family in a hollow tree next the railroad track in the station-yard at Atlanta, where the smoke of every passing locomotive enveloped their house; but engineers let off steam and do much bell-ringing when about the yards, and these woodpeckers evidently enjoyed the din enough to compensate them for the smoke and publicity.

To hear the kingfisher flying up stream advising his mate that he is coming home, one might suspect that he, too, is an instrumentalist, his instrument being a policeman's rattle. The cuckoo also has a peculiar rattle, $k r-r-r-r-r-u c k-u c k$-uck, suggesting a great tree-toad; but neither of these birds may be used to swell the short list of instrumental performances. Both are vocalists.

\section{PEERLESS MUSICIANS}

But when we speak of vocalists no one has in mind either kingfisher or cuckoo, or the screaming blue jay that goes roving about through the autumn woods with a troop of noisy fellows, or his cousin the crow, or the wheezy grackles whose notes sug- 


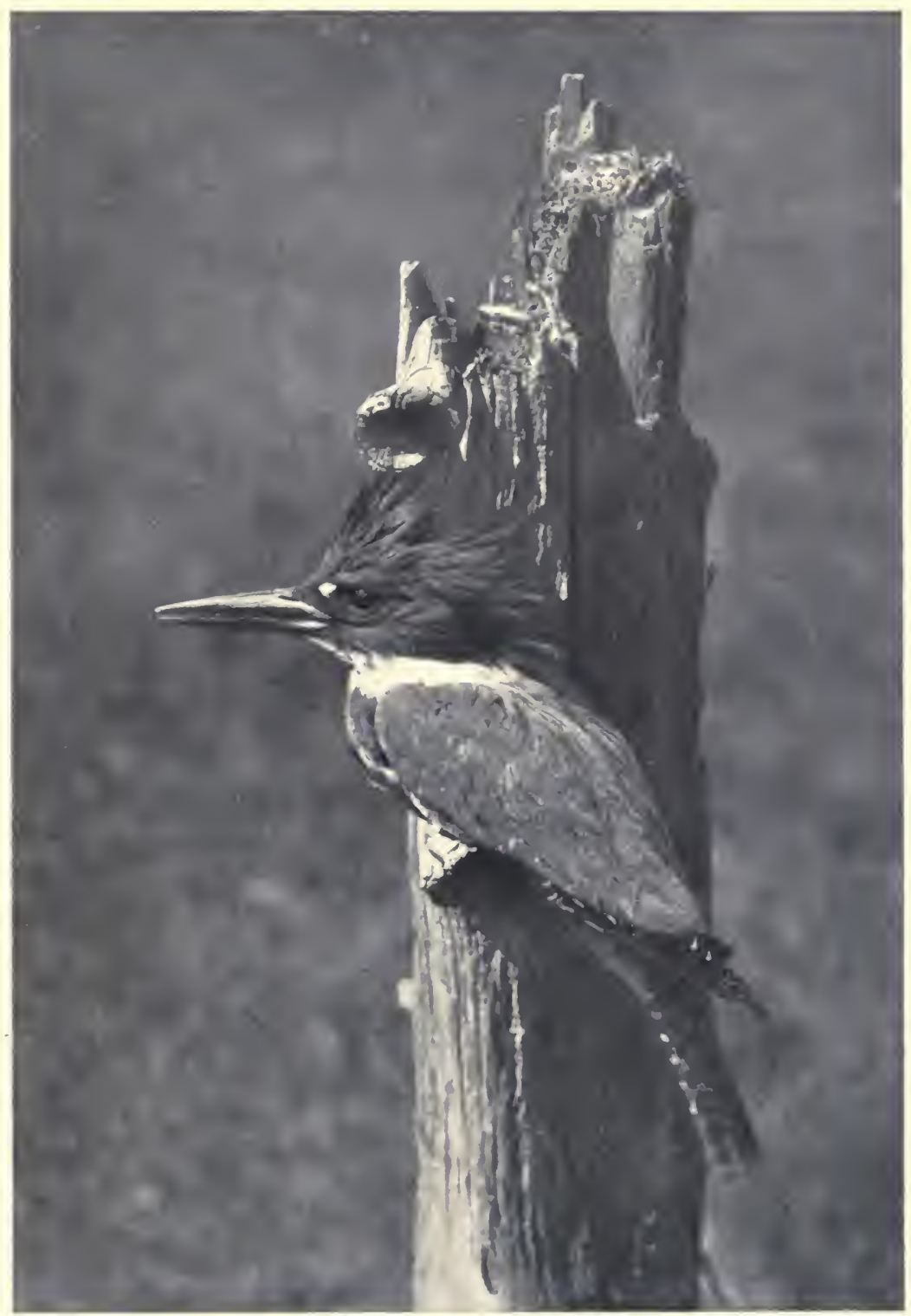

An instrumentalist with a call like a policeman's rattle.- Kingfisher 



\section{Songs Without Words}

gest wagon-wheels in need of axle-grease, or the uncanny owls whose hoots make night hideous, or strident hawks, or wild geese honking as they speed high above us in a wedge-shaped flock. To him

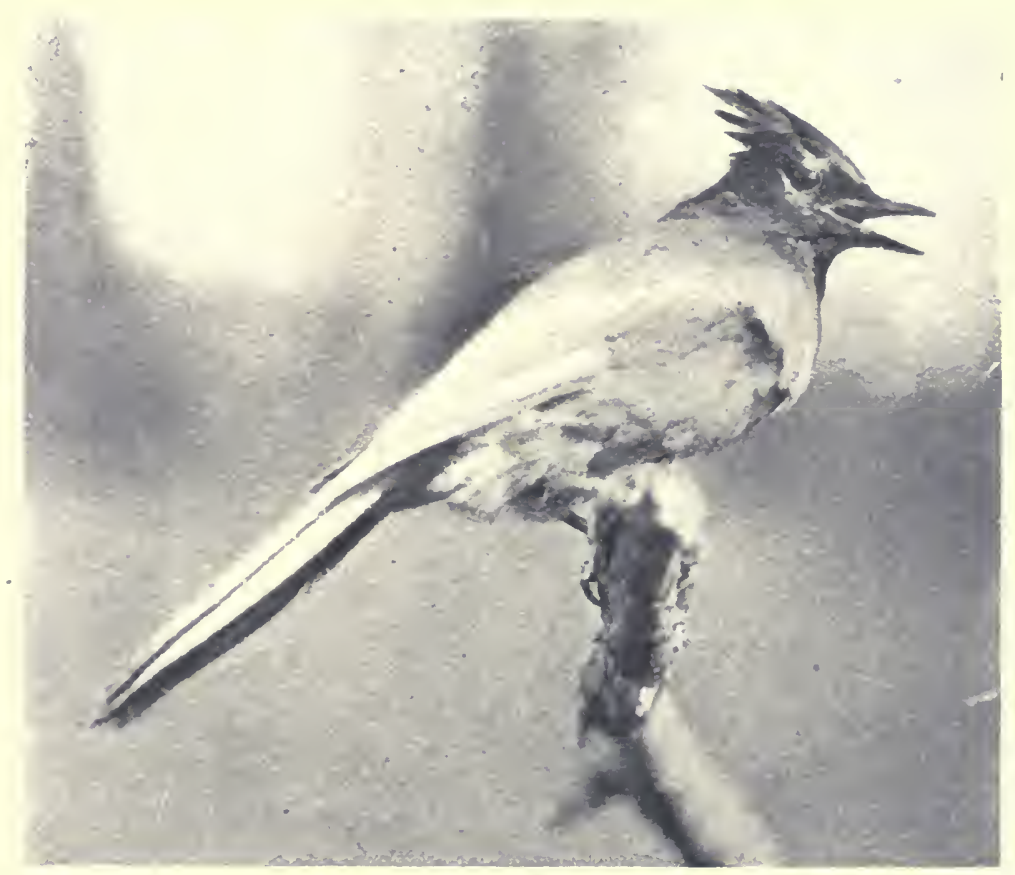

The blue jay - mimic, ventriloquist, tease and rascal

that hath ears to hear even these are musical. No; the real star performers of the world are such as buy no castles in Wales with the proceeds of a single concert tour, but shy, often persecuted creatures, which, like the hermit thrush, lift up their heavenly voices in woodland solitudes with only a devoted little mate for an audience. Love alone inspires these highest attainments. Neither for applause nor hope of gain does the mocking-bird fill the southern 
How to Attract the Birds

groves with its enchanting melody, or thrushes peal their silvery bell-like notes through northern woods. For beggar or king the humble little field-sparrow makes no variations of its exquisite song. The gor-

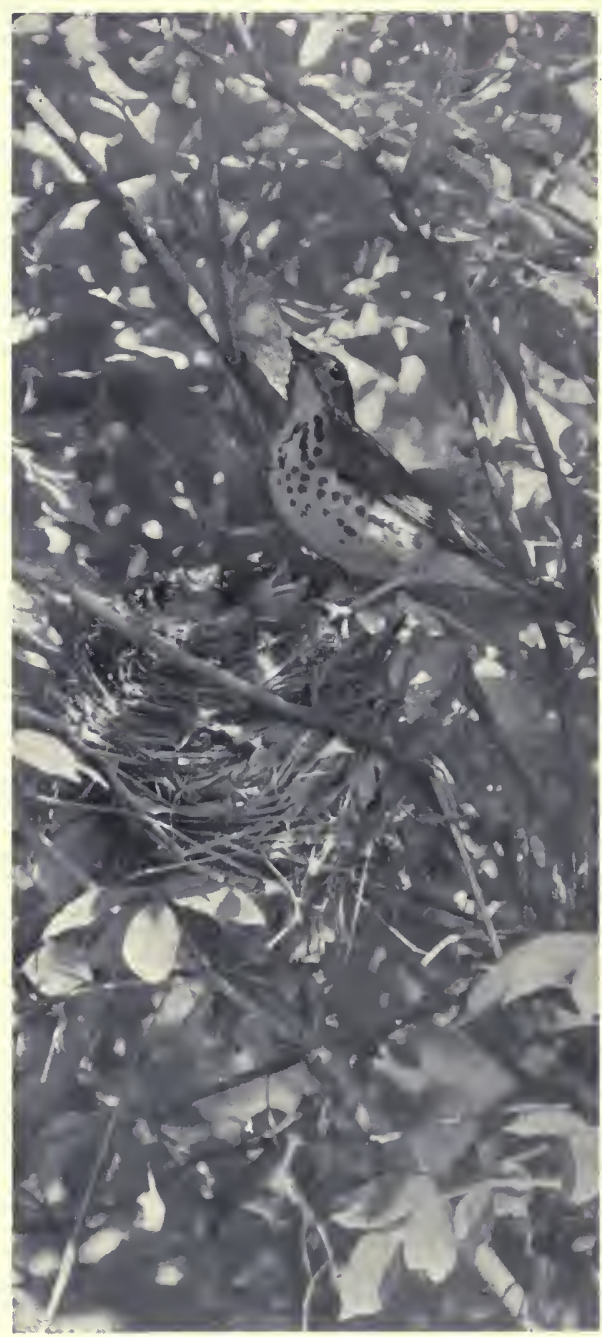

'The wood-thrush g e ous cardinal's rich whistle, the b obolink's hurried, tripping cadenzas, the wren's tuneful frolic, the vesper-sparrow's hymn-like benediction at close of day-all are free as salvation! It is the unearthly, soulful quality in a. bird's voice that thrills one with shivery creeps of sympathetic vibration.

\section{WHEN BIRDS SING}

In February, before we have begun to look for pussy - willow's or skunk - cabbages, the song-sparrow's sweet, sprightly 


\section{Songs Without Words}

"merry cheer" opens the concert of bird music. Presently robins, bluebirds, blackbirds, and other migrants returning from the south in advance of the females, burst into joyous songs of expectancy, every day adding some new minstrel to the choir, until toward the end of spring the birds are holding such a May festival as Theodore Thomas never conducted. Late in the merry month nearly every throat that can make music is rippling, whistling and warbling its utmost best; for a bird's season of song usually corresponds with its

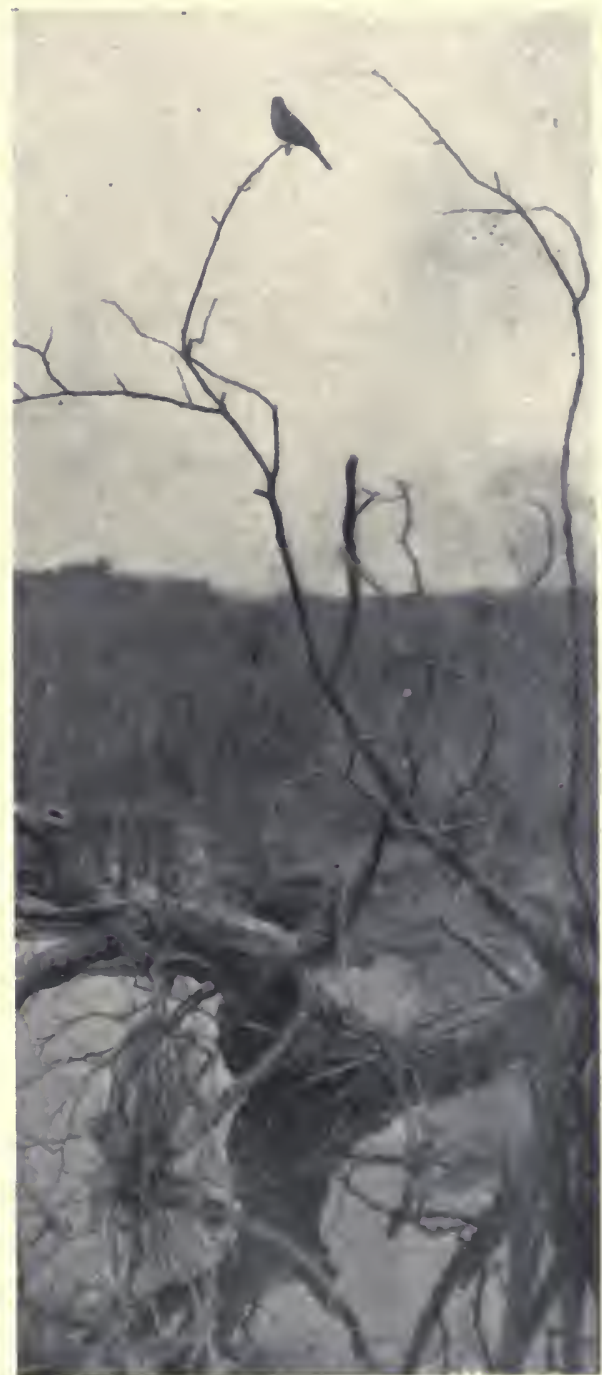

The song-sparrow chooses a conspicuous perch for his performance nesting season. Some musicians, it is true, attune their voices long before the courting days, yet in 


\section{How to Attract the Birds}

anticipation of them; and they still have enough vitality left after they have helped raise two broods and have molted their feathers, to 'express enjoyment of life in song. Either or both of these physical strains is enough to stop some birds' melody altogether. One rarely hears a bobolink after the fourth of July. Few birds, indeed, attempt to sing after family cares and midsummer heat and the growing of new feathers deject their spirits. Such as continue through these ordeals usually drop so many notes that one can scarcely recognize the broken fragments of their real song. But after the new suit of clothes is well on, whether it is joy in the possession of them or a returned sense of physical well-being, in early autumn a second singing usually begins - not so long, nor so exuberant, nor so pleasing, but still a welcome reminder of spring joys.

\section{THE DEVELOPMENT OF BIRD AND HUMAN MUSIC}

Whether the evolution of bird music has paralleled that of our own is not yet a settled question among scientists, but a great mass of evidence seems to prove that it has followed similar lines, and that its tendency is still toward the same ideal. We have already noted that it is the quality of voice, not so much the intervals of the melodic scale, that differentiates avian from human music. That sense of rhythm is variously developed among birds we realize on comparing the Carolina wren's precisely emphasized beats with the jumbled jargon of that rollicking polyglot, the Maryland yellow-throat. All 


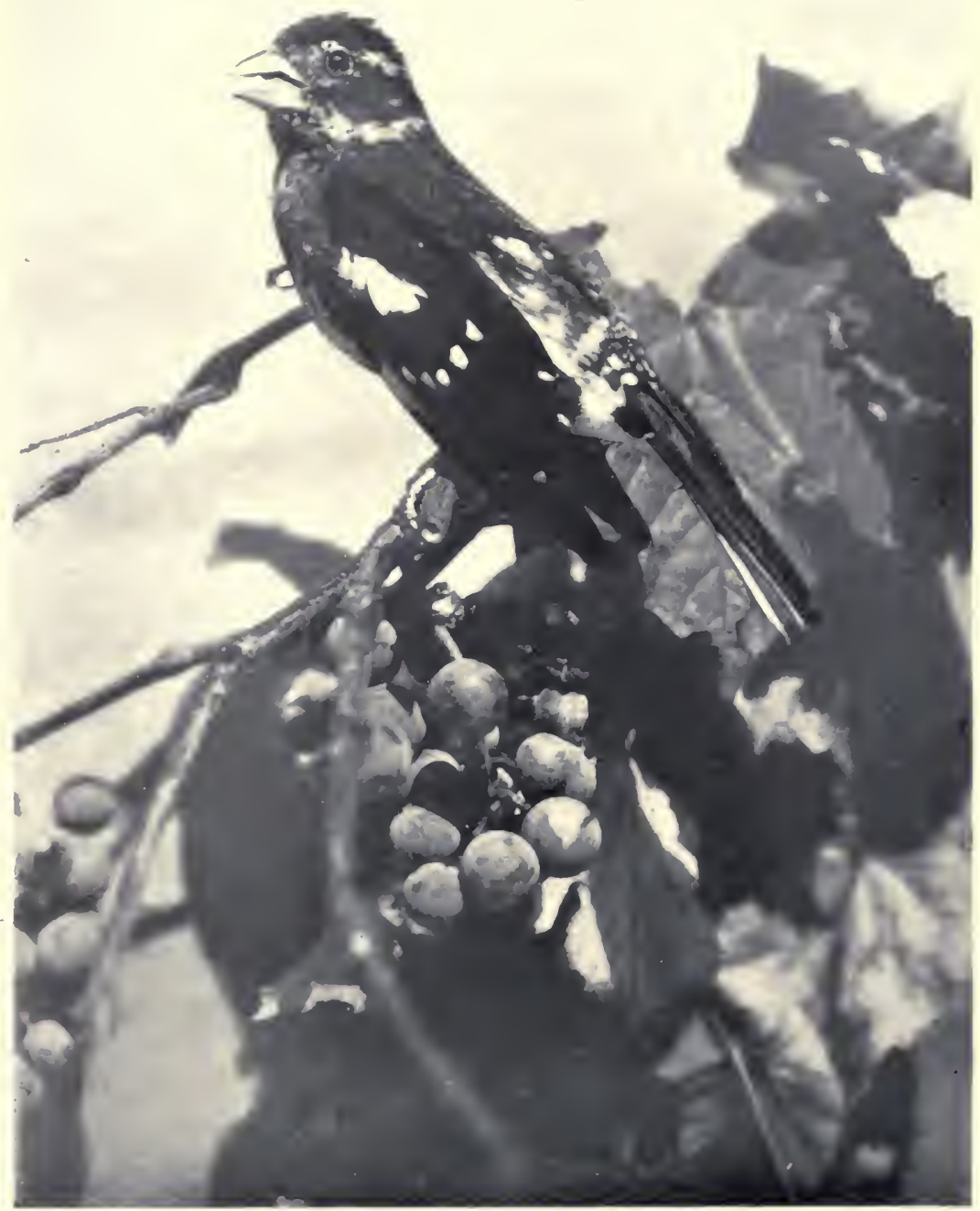

One of our sweetest though unappreciated songsters - the rose-breasted grosbeak 



\section{Songs Without Words}

the intervals of the major and minor scales that we can write, as well as some too elusive to record, are used by birds in perfection of tone. They employ very effectively repetitions of notes and phrases, sometimes so combined as to produce a formal theme,- - some birds of quite limited powers thus producing the most pleasing results. They trill on two notes or more, introducing a finer tremolo than a pipe-organ's. Antiphonals are indulged in by sev. eral of the tuneful sparrows, chewinks and meadowlarks; in short, they make unconscious use of musical intervals and methods that men have formulated into laws. Because they are laws, we are just beginning to realize that they may be of wide enough application to include the birds' music. Above all, there is a purity, an exquisite quality of a bird's song, with which no other on earth is to be compared. That music such as theirs can be written at all in the set forms that we use for ours would seem to indicate that the lines of development of both are not so divergent as one at first might suppose. Foremost critics declare that the opera and oratorio of the future will be sung, like bird music, without words. 

WHY BIRDS COME AND GO 



\section{CHAPTER VII}

\section{WHY BIRDS COME AND GO}

WhOever notices what is going on in the natural world about him must be impressed with the fact that no two months in the year are alike so far as the bird population is concerned. In winter, bird life is at its minimum; in June, at its height ; and between the two extremes there is constant fluctuation. Great flocks of migrants stream southward across the sky in autumn. Then, if we search the heavens with a telescope on moonlight nights, we find the vast procession stealing a march on its watchful enemies of the day, some detachments moving slowly, laboriously; others, like the wild ducks, at the rate of over a mile a minute. Hour after hour, both by day and by night, day after day, week after week, the procession passes; yet in the spring, doubtless, every one of these birds that has survived will reverse the tedious journey. With the coming of warm weather we waken every morning to find in our gardens birds that may have been a hundred miles away-yes, or even a thousand-only the day before. Chimney-swifts fly at almost incredible speed. Audubon picked up in Kentucky a dead wild pigeon in whose crop were berries that did not grow nearer than five hundred miles from his home, yet they were only partly digested! Why do so many birds attempt these wearisome journeys twice a year? 


\section{How to Attract the Birds}

What relentless impulse drives the little travelers back and forth, north and south, here to-day, away to-morrow?

\section{CONSTANT FRIENDS ARE FEW}

Wherever you live you will find that some of the birds about you are more or less in evidence the year round. If you walk far enough you are likely to see a crow or a sparrow, for example, any month

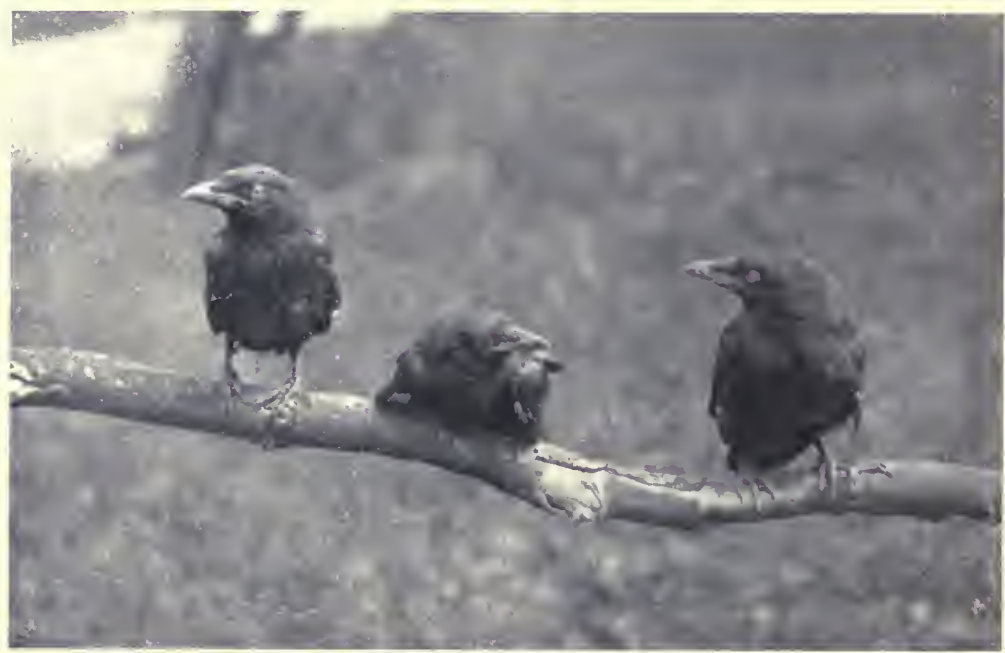

"Crows, like the poor, are always with us"

in the twelve. But other birds simply pass regularly through your locality on their spring and fall migrations, barely affording a glimpse of their feathers as they hurry by. With such disdain are we treated by the majority, but not all, of the warbler tribe,charmingly-colored, restless, dainty little sprites which flit among the spring blossoms for a day or 
two on their way to Canadian forests, where so many nest. These are the days when one grudges every moment that must be spent in the house; such rare guests do us the honor to pause awhile at our very doors, affording us, if not an opportunity for intimate acquaintance, at least the chance to know them again by sight. Within six months increased numbers of these warblers will stop again for a hasty lunch of insects, in the garden shrubbery and orchard, to refresh themselves on their journey back to the Gulf States, Central or South America or the West Indies. Clever little creatures, thus to live in perpetual summer! Some of the old birds having exchanged their wedding clothes for more quiet suits, and some of the young ones not yet wearing the feathers of maturity described in the books, the poor novice is often sadly bewildered in autumn, by not recognizing in its change of clothes a species he may have identified easily in spring. He misses, too, the characteristic songs and call-notes of the courting season; because the autumn travelers are mostly silent, they slip by unobserved.

The migrants, then, must be classed among one's fair-weather friends, and these, like human ones, alas! constitute the largest class. But no reproach on the birds is intended by this comparison: theirs is a motive compelling desertion when conditions of life become too hard for endurance in our neighborhood. Thus the robin and bluebird remain constant residents in some favored parts of the United States, while, in others, conditions make of them summer residents only. You may know the wood-thrush as a migrant, while to me he may be a near neigh- 


\section{How to Attract the Birds}

bor from May to October; for the bird population differs in different localities, though they may be not more than ten miles apart, just as surely as it differs from month to month everywhere. Why, you see different birds at different hours of the same day!

That is one of the rea-

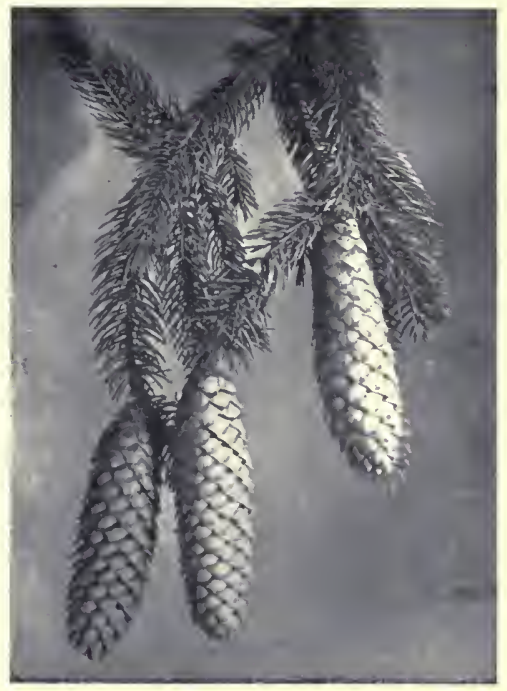

"Where Chickadees delight to dangle" sons why bird study is of perennial interest; there is about it always the charm of variety and the unexpected.

No sooner have the summer residents and the more tender migrants deserted us in the fall than certain hardy birds regularly appear; some, like the chickadees, merely from deep woods where they have nested; others, like the sea-gulls in our harbors and the Great Lakes, from inaccessible nesting islands off the northern coast; still others from the region of the north pole. But whether the so-called winter birds come from the next county or from the arctic regions, they are in evidence about our homes only at the most inclement season. With the return of the sun, bringing joy and abundance in its train, away go chickadees, nuthatches, kinglets, winter wrens, longspurs, juncos, snow-buntings, crossbills, redpolls, shrikes and gulls,- not to be seen again until the frost or snowfalls of next autumn. 


\section{Why Birds Come and Go}

HOW IS THEIR CALENDAR REGULATED?

In spite of this constant shifting of the feathered population, there is astonishing system and punctu-

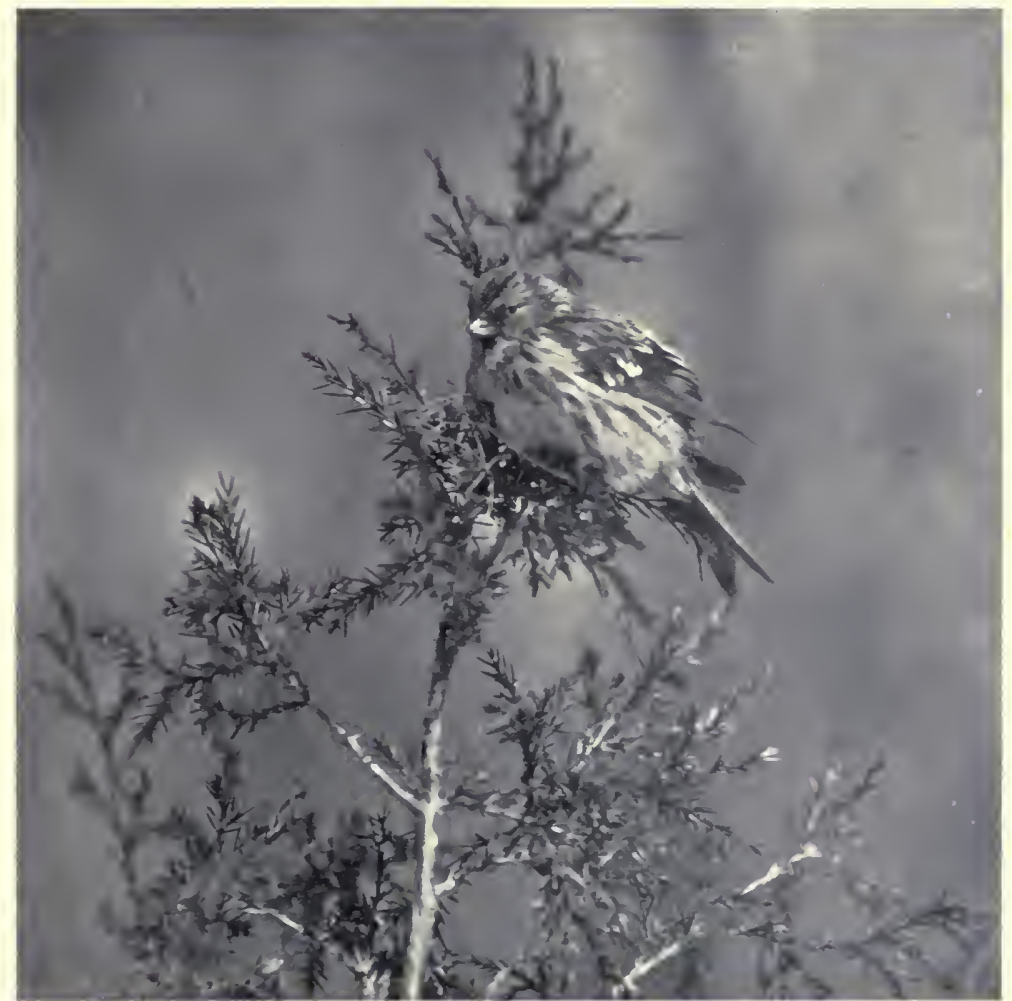

"A cold exposure" - Redpoll on a cedar tree

aiity of appearance and disappearance of the greater part of it, one discovers on keeping a bird diary, which, by the way, is even more interesting than Pepys's. For thirty years the purple martins reached a certain home set up for their benefit in a New Jersey garden, on the 26 th, 27 th, or 28 th of April, 


\section{How to Attract the Birds}

leaving it as regularly on one of four dates early in September. Sportsmen know almost to a day when ducks, plover and snipe may be found in the marshes. There are late springs and early springs; a belated blizzard may freeze back the budding fruit trees, raging storms may retard the progress of many a northbound flock, but the going and coming of nearly all birds may be reckoned just as certainly as the coming of apple blossoms. One confidently listens for the first bluebird's song in March, when poking about in the leafless woods for the first hepatica. When shad ascend the rivers from the sea, and the shadbush stretches out fleecy white blossoms from the woodland borders with wild, irregular grace, then the Indians taught us to expect the first night-hawk's uncanny, mournful, jarring sound.

\section{FEATHERED NOMADS}

All birds, however, are not so punctual in their goings and comings as a railroad express, by any means. Some few species habitually lead a gypsylike existence, roving hither and yonder, not as fancy dictates altogether, although their movements certainly appear erratic. Flocks of lisping, twittering, amiable cedar-waxwings, clad like Quakers but having a rather frivolous crest, may visit you for a week if there are plenty of choke-cherry and juniper trees about, yet one may not come again for a year. In addition to the more or less familiar visitors whose habits are known to be roving, occasionally, rarely, a total stranger to your neigborhood appears. Some extraordinary natural phenomenon in one part of 
Why Birds Come and Go

the world often affects the bird population in a place very far distant, as when a sooty tern belonging on the Florida Keys got caught in a tornado and was blown northward until it had lost its reckonings. Finally, it was picked up exhausted in a

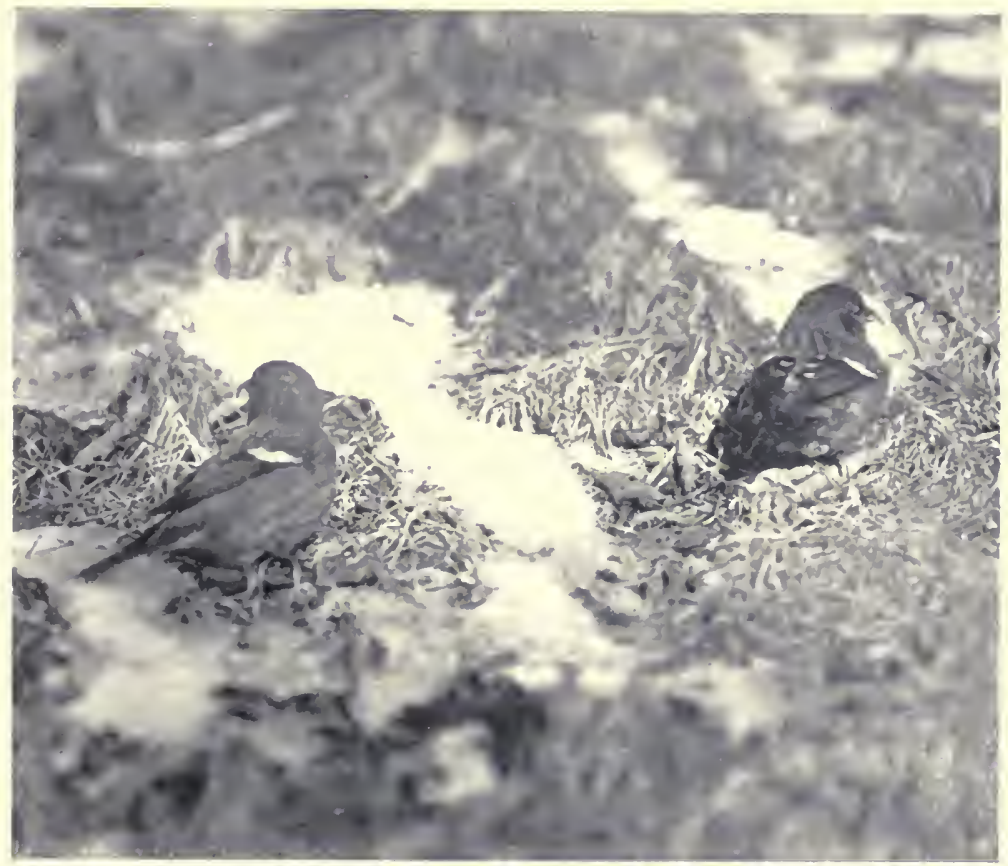

"Erratic winter visitors" - White-winged Crossbills

Hudson river village. On some winter walk, that rare apparition, a great, blinking, snowy owl, from the arctic regions, may startle you, like a ghost among the evergreens. Quantities of red crossbills came far over the Canadian border a few winters ago. Bird lovers wrote each other excited letters in their joy at finding these charming, friendly little 


\section{How to Attract the Birds}

strangers pecking at the seeds in the cones of their pine trees. Cameras didn't frighten them. It may be a decade, perhaps a lifetime, before the severity of the cold at the north or a driving storm sends such numbers to us again. Doubtless the warm reception of hot-shot they received in some places had much to do with their sudden disappearance. One zealous ornithologist - of all men!-calmly told of killing eighty crossbills to learn what kind of food they had in their stomachs! These are the little birds which, legend says, dyed their breasts crimson and twisted their bills awry in their struggle to pull the nails from our crucified Saviour's hands and feet.

\section{FIVE DISTINCT GROUPS}

As permanent residents, summer residents, winter residents, migrants and visitors, whether regular or uncertain, we may, then, classify the birds; but, however their habits may differ, one chief motive impels the going and coming of them all - the finding of adequate food. Perhaps, in the spring migration, this is more for the sake of the young than for the parents themselves. Fish migrate to spawn, running into harbors and rivers from the sea, leaping cataracts and mill-dams, if need be, to reach quiet, shallow, warmer waters, where there is greater hope of protection from foes and more suitable food for small fry left to make their own way in life without either parent or guardian. Probably birds are influenced by similar considerations when they migrate. 


\section{Why Birds Come and Go}

Of course the food question incites the greater part of the activities in our own world; and be it observed that birds and other wild creatures seek those places where the food on which life itself depends is abundant just as unerringly, with just as much intelligence and forethought, as men do. When conditions prove too hard in Russia, Italy or Ireland, a great stream of human immigrants pours into America - greater in our prosperous years than in the lean periods of financial depression. When the birds are starved out of frozen Canada and the northern states, they go south, where the proverbial hospitality of that genial land will be extended to them by nature. Those which can live on pine seeds, insect eggs, larvæ, and grubs hidden in the bark of trees, the dry, seedy weed-stalks that rear themselves above the snow, the fish and refuse in the open waters of our larger streams, lakes and harbors, may safely remain at the north all winter, and they do. But we shall never find a flycatcher north then. To escape competition from the horde of contestants that pours out of the south in spring, the winter residents beat a retreat on their approach. Plenty of birds do not find it necessary to shift their residence farther than the next state in order to live in a land of plenty. Robins from Ohio may find Kentucky perfectly satisfactory as a winter resort. Robins, crows, and wild geese often sleep in one state and eat in another, going and coming daily as regularly as sunrise and sunset from one to the other. Geese, which prefer to sleep a-float, fly early to inland feeding grounds to spend the day - that is, if hunters are not waiting in ambush to receive them. 


\section{A FEW WONDERFUL TRAVELERS}

That it may have the entire field to itself and escape the keen competition of hosts of tropical relatives for the nectar and minute insects in the deep-tubed, brilliant flowers that please him best, we have seen that the ruby-throated humming-bird

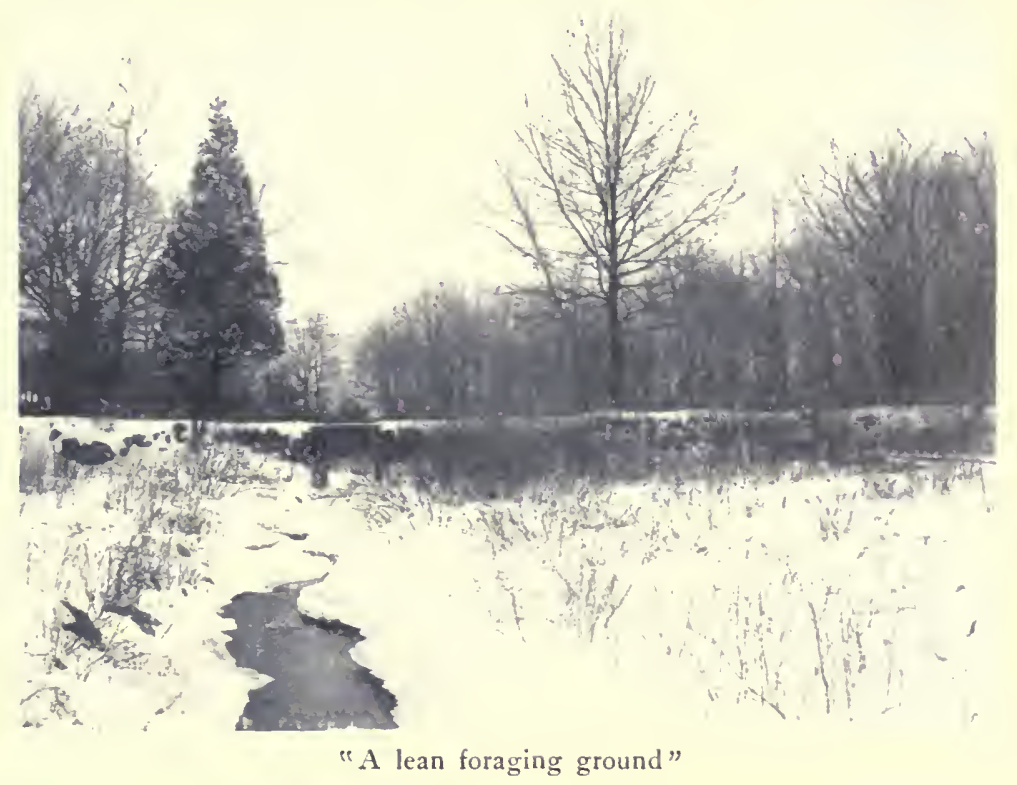

travels from Central America, or beyond, to Labrador and back again every summer of its incessantly active little life. Think what the journey from Yucatan even to New England must mean for a creature so tiny that its outstretched wings measure barely two inches across! It is the smallest bird we have. Then what must be the size of the body itself beneath its dress of feathers? Wherein 


\section{Why Birds Come and Go}

lodges the force that propels it through the sky at a speed and a height which take it instantly beyond the range of human vision?

"There is a Power whose care

Teaches thy way along the pathless coast,

The desert and illimitable air,

Lone wandering, but not lost.

"He who from zone to zone

Guides through the air thy certain flight,

In the long way that I must tread alone,

Will lead my steps aright."

Leaving our grassy meadows in August, the joyous, rollicking bobolinks go to feed on the wild rice in our southern states, en route for Brazil; and some may count themselves fortunate if they do not end their journey suddenly as reedbirds, which, plucked and broiled, are served at the epicure's table.

As near the north pole as Grinnell Land, General Greeley found ring-neck plovers nesting in July; yet the young birds, hatched at this late day, were ready by the end of August to journey toward the Amazon country, their winter resort. Many birds must divide their residence between the upper and the lower half of the globe to secure a living. Sandpipers travel between Alaska or Greenland and Patagonia twice a year as a matter of course. Man does not appear to be only a little lower than the angels when he is willing to take advantage of the tameness of these birds, which, because they have been reared in out-of-the-way corners of the earth where he is practically unknown, allow him to ap- 


\section{How to Attract the Birds}

proach with his gun, when their autumn flocks are resting awhile among us, near enough to rake the last innocent

\section{HOW SOME BIRDS TRAVEL}

In spring some happy couples, already mated, travel northward together; or, all the males may come in one flock, a sort of bachelor's club, ungallantly leaving the females to find their way alone. Then, how these same bachelors sing to advertise their locality when possible mates are expected to arrive!

Different species have different traveling methods, and even the same species does not always follow the same method in spring and fall. Some of the wild ducks, for instance, which go southward in large family parties, return in mated couples, very tenderly attached to each other one might think who had never observed the dandified drake calmly desert his partner just as soon as nursery duties threaten to interfere with his leisure and pleasure. The devoted phœbe, in his somber drab suit, sits about near last year's nest very early in spring, calling repeatedly to a mate that may be many miles away; but in a few days how unerringly she finds the old home, and the faithful lover waiting at the trysting-place beside the bridge to welcome her! The joy of such reunited lovers puts a song into the heart of all beholders.

When the cares of a young family beset them, and when old feathers must be replaced by new ones during July and August, birds are seldom sociable. 


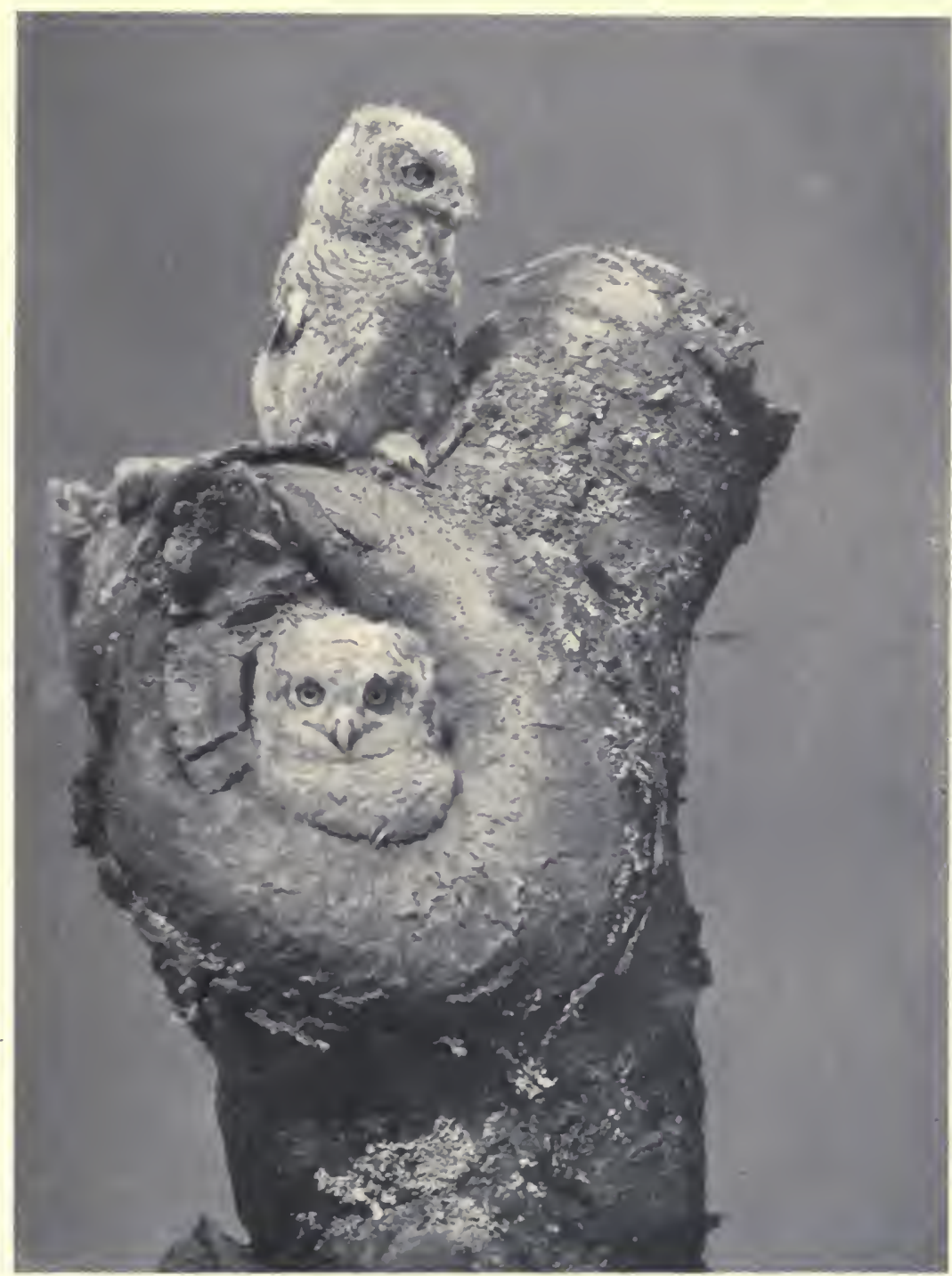

Permanent residents without the flocking habit - young screech owls 



\section{Why Birds Come and Go}

The males of only a few species, that sleep in clublike roosts even at the nesting season, must be excepted. Indeed, so silent and moping are the vast majority when molting that they seem to have entirely disappeared. In the course of a walk through the midsummer woods we may neither see nor hear one. But with the proud consciousness of new clothes and the return of energy with the cooler weather, out they come from their rest-cure retreats, refreshed and even tuneful again, ready to welcome as friend any bird of the same feather, to collect into family parties, or join any passing band of good fellows which receives not only individuals but small roving flocks, one after another, day after day, until, perhaps, many thousands so assemble. Now the meadows and marshes are alive with swallows, and the telegraph wires, strung with them, look like bars of printed music-scrolls stretched across the sky. Now, robins, chewinks, and thrushes congregate along woodland borders, to feast on dogwood or whatever bright berries cling to the trees and bushes waiting for just such distributing agents as they. (For how much of the earth's beauty are not birds, the seedcarriers, responsible!) Mr. William Brewster declares that he has found as many as twenty-five thousand robins sleeping together in one roost. It is well known that crows, likewise, roost in enormous numbers. At the approach of cool weather even the English sparrow, although at no time a shy recluse exactly, becomes intensely gregarious. Great num bers of sparrows - sometimes a sprinkling of the rarer cousins in the flock-settling on the lawn, speedily clean off the seeds of whatever grasses may 


\section{How to Attract the Birds}

have got ahead of the mowing machine. Large companies of feeders must necessarily be rovers. Now, flocks of slate-colored juncos appear among the late asters and goldenrod by the waysides. Hosts of old friends come back to us every day; some new acquaintances may turn up at any hour.

High up in the air, sometimes a mile or more above the earth, if the weather be clear, travel flocks of migrants where they can obtain a bird's-eye view of the country to be traversed. Geese have been detected four miles high. Rivers running like silver threads across the

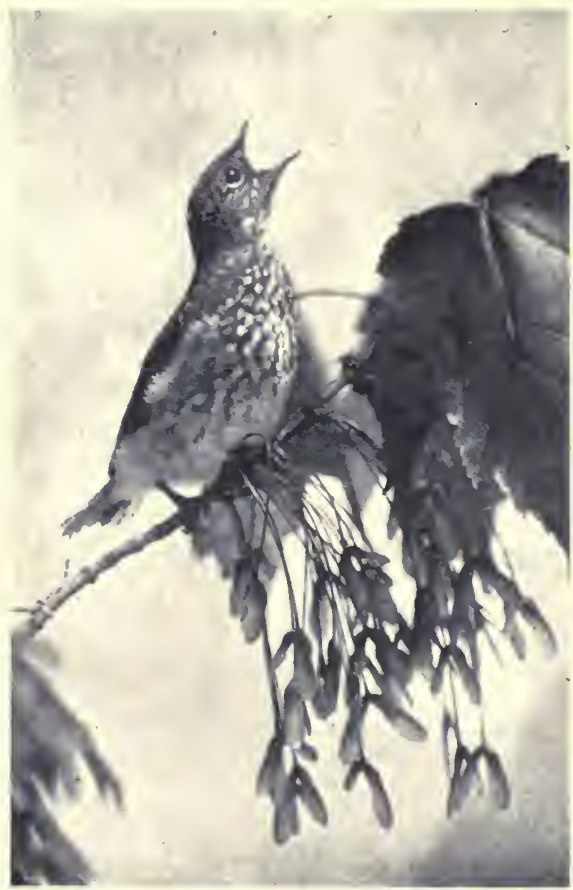

Young Bluebird resting for refreshments after wing practice. A candidate for a personally conducted excursion next November map, mountain ranges, valleys, and the seacoast line, must be far more familiar to the birds that follow them systematically than to Macaulay's schoolboy. Only large, strong, or courageous birds dare travel in broad daylight. A mellow honk, honk from the veteran leader of a wedge-shaped flock of wild geese will be answered all along the ranks by his lusty followers, lest any straggler 
should be lost; for sound as well as sight aids their flight. The twitterings and pipings of the birds that pass in the night float earthward to our listening ears from the dark vault overhead, where they move unseen by friend or foe.

In autumn, great numbers of migrants dash to their death against the lighthouses along our coasts, partly because many are young, inexperienced, wayward travelers; partly because fog now often obscures their course, and chiefly, because they are irresistibly attracted toward the bright, cheerful beacons, much as moths are drawn to the flame. Young birds have learned to fly swiftly in a straight line before they can steer their bodies well. Once launched on a long flight, it is easier to keep going than to stop short. Immature cedar-waxwings, for example, do not lag behind their swift parents when they fly in a straight course above the tree-tops; but I have picked up in September the dead bodies of more young waxwings than I care to recall, simply because, in flying low between one choke-cherry tree on the lawn and another on the road, they couldn't turn out suddenly enough to escape the corner of the house that stood in a direct line between the trees, and so they broke their poor little necks by dashing at top speed against the piazza posts.

\section{HAVE BIRDS A SIXTH SENSE?}

Opposing theories to account for the migratory instinct are advanced by scientists. By some it is contended that peculiar acuteness of the five senses, inherent in all animals, would account for the birds' 


\section{How to Attract the Birds}

faculty of finding their way from one region to another, even from one continent to another, with precise regularity, which birds alone possess in the highest degree. Other scientists insist that orientation, the instinct of determining direction or relative position in general, brings into play a sixth sense not dependent on the other five. Doubtless the descent and withdrawal of the ice in the glacial period had much to do with the origin of the migratory habit. Certain it is that only a bird which has once made a journey can find its way back to the starting point. Therefore, every young traveler must be "personally conducted" by a veteran. A bird will always return, if possible, to the region of its birth. It knows no other course to follow than the one once taken. A wounded young bird that is not able to leave with the south-bound flock in autumn and recovers strength too late to overtake it, must remain perforce at the north. If the food it requires fail, die it must, for by no possibility could it find its way alone to a land of plenty. The soaring lark, which "at heaven's gate sings," has been imported to this country from Europe, only to die, in most cases, because, at the approach of winter, it couldn't migrate over unknown territory, and couldn't find food enough in our snow-covered northern fields, where, however, it was perfectly content in summer.

In all probability the journeys undertaken by birds at first were short, roving excursions from home; gradually the routes traversed were lengthened of necessity, until, in generation after generation, the habit of traveling became hereditary; the "homing instinct" led little by little to fixed migra- 


\section{Why Birds Come and Go}

tory habits. The entire subject stirs our imagination as no other phase of bird life does; for, after all has been said about migration by the scientists, the wonder and the mystery remain.

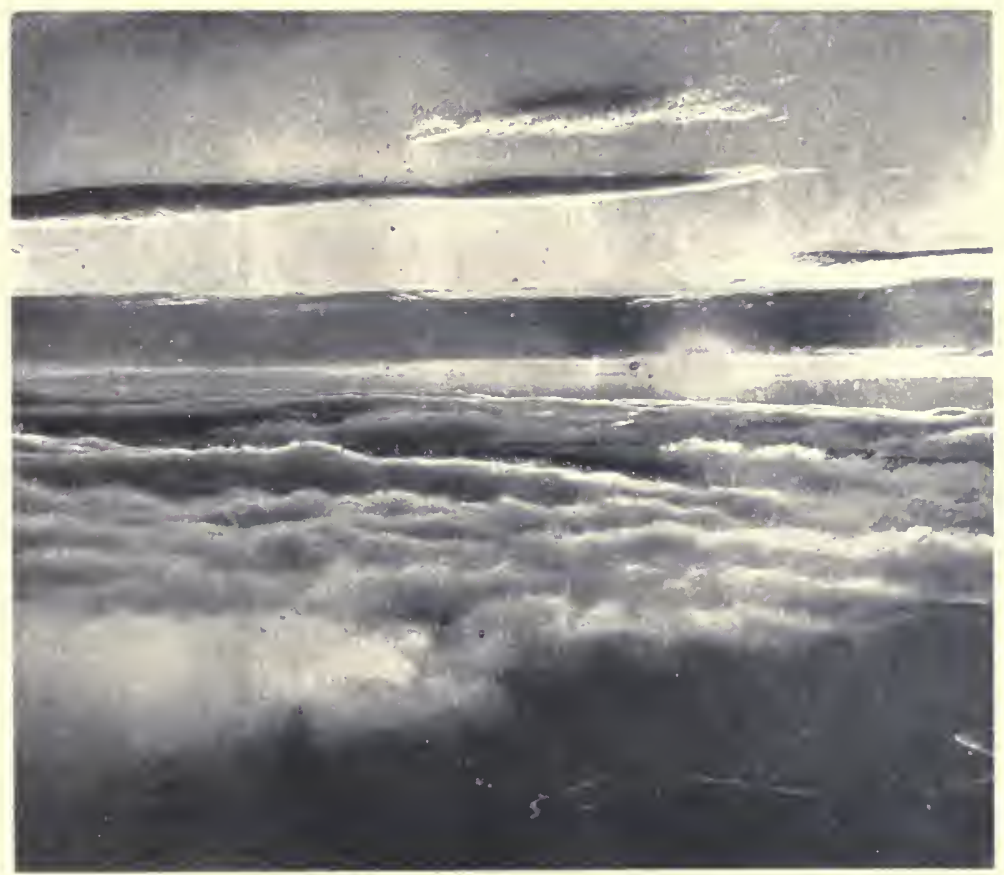

A clear highway for the migrants between fog and clouds 

WHAT BIRDS DO FOR US 



\section{CHAPTER VIII}

\section{WHAT BIRDS DO FOR US}

MAN's attitude toward nature reveals a long step in his evolution. Shocked now and again into sudden recognition of her power by some mighty, destructive phenomenon-an earthquake, volcanic eruption, cyclone or flood-undeveloped man of all nations, trembling with terror, purchased ease of mind only by offering sacrificial gifts to appease the wrath of imaginary gods, and then straightway relapsed into indifference. Her gentle, kindly ministrations every hour of his life, her marvelous beauties, impressed him not at all. Whenever he thought of nature it was of something mystic, beyond his comprehension, evil, terrible.

Even the matchless art of the Greeks reveals no appreciation of natural beauty beyond the glorified human physique. For all the great masters among early Christian painters, for Raphael, Michael Angelo, Correggio, the lovely, smiling Italian Eden lying around them did not exist. It was literally beneath their notice, fcr their sight, lifted perpetually heavenward in search of subjects, could include nothing but clouds as natural settings for their Madonnas and cherubim. Not until the last century did artists come down to earth and discover the landscape for the people. And not until the last generation has nature study, the trained observation 


\section{How to Attract the Birds}

and love of nature, the most spiritualizing of all his lessons, formed part of the American child's education.

One of our greatest religious thinkers has recently set himself the task of getting acquainted with the trees, birds and wild flowers around his summer home. "When I was a boy," he says, half apologetically, "we never noticed these things. The good people fixed their thoughts so steadfastly on the next world, they quite overlooked this. We left nature unread then, thinking that everything worth knowing had to be studied out of lesson books. And the idea of knowledge that obtained in a New England academy was almost mediæval. It bore almost no relation to the people's daily lives. Where nearly the entire population earned a living from the soil, absolutely nothing was done toward making the people understand it and love it. Is it any wonder that farming meant failure so often and that the ambitious young people rushed madly toward the cities? We are only just learning to enjoy nature, to open our blind eyes and see the world around us, to stop destroying and preserve the beneficent gifts lavished upon us, to utilize them intelligently, which is to agree with our Creator that His creation is good."

\section{A NEW THING UNDER THE SUN}

In the quite sudden popular interest in nature recently manifest, birds have come in for, perhaps, the lion's share of attention. Unlike most movements, this is an absolutely new one in the history of 

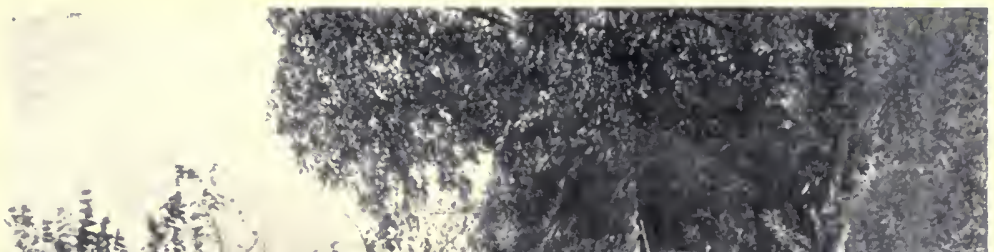

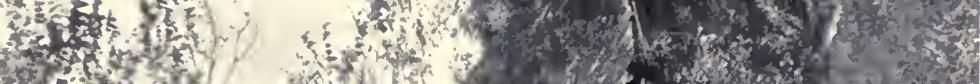

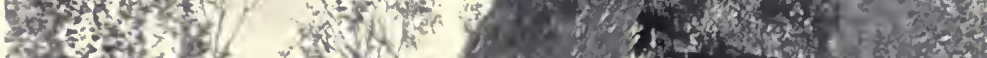
T.

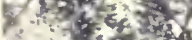

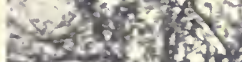

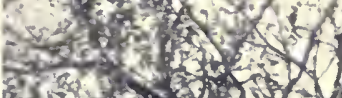
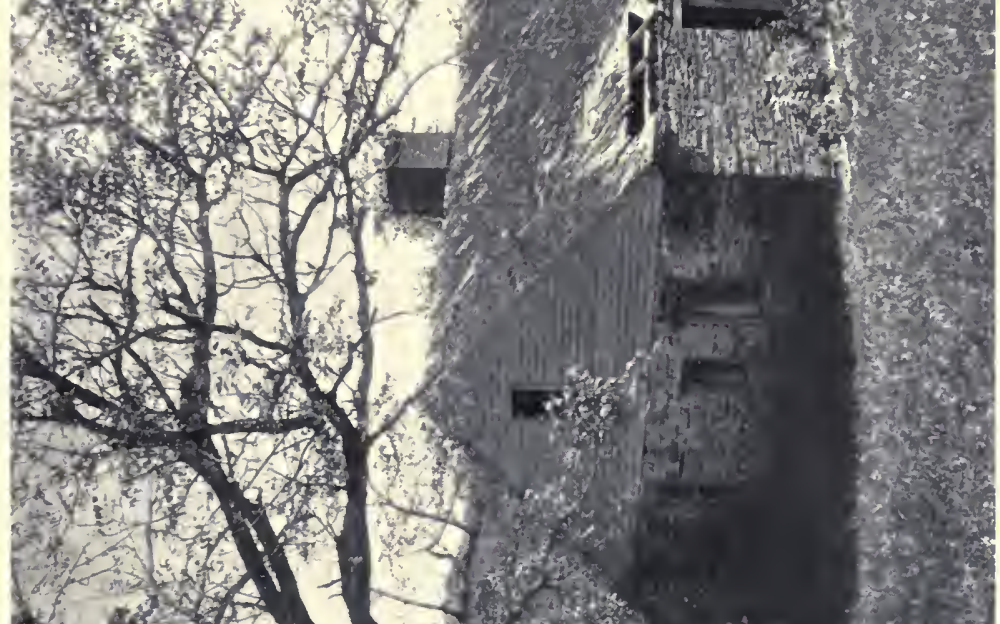
aristive?

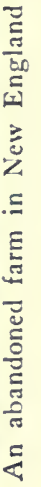

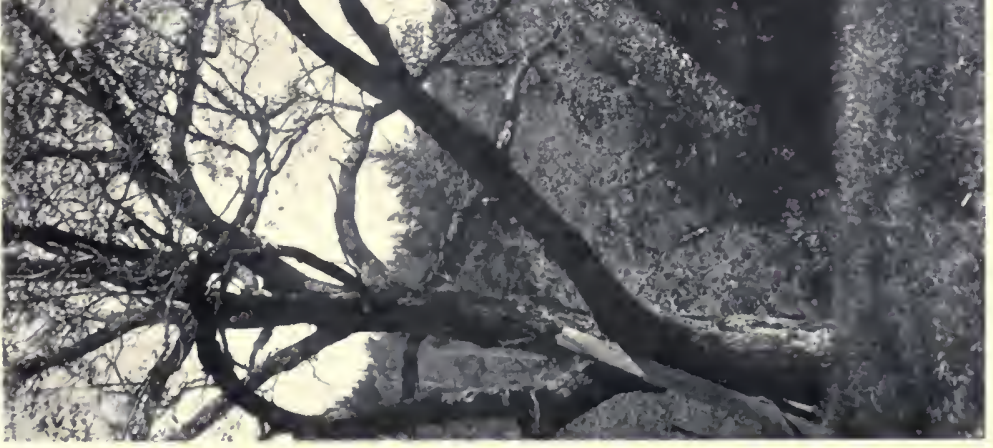



the world, not a revival. One might have thought that so intensely practical a people as the Americans would have taken up economic ornithology first of all, have learned with scientific certainty which birds are too destructive for survival and which so valuable that every measure ought to be taken to preserve and increase them. In reality this has been the last aspect of the subject to receive attention. First came the classifiers - Wilson, Audubon, Baird, and Nuttall - the pioneers in systematic bird study. Thoreau was as a voice crying in the wilderness. His books lay in piles on the attic floor, unsold many years after his death. It remained for John Burroughs to awaken the popular enthusiasm for out-ofdoor life generally and for birds particularly, which is one of the signs of our times.

Among the first acts passed in the Colonies were bounty laws, not only offering rewards for the heads of certain birds that were condemned without fair trial, but imposing fixed fines upon the farmer who did not kill his quota each year. Of course every man and boy carried a gun. The bounty system did much to foster the popular notion that everything in feathers is a legitimate target. Thus it is that

\section{"The evil that birds do lives after them; \\ The good is oft interred with their bones."}

For two centuries and a half this systematic destruction of birds, which blundered ignorantly along in every colony, state and territory, resulted in a loss to our agriculture whose colossal aggregate would "stagger humanity" if, indeed, our minds could grasp the estimated figures in dollars and cents. Men now 


\section{How to Attract the Birds}

living among us were absolutely the first to study the food of any one species of bird through an entire year and in various sections of the country, and to pass scientific judgment upon it only after laboratory tests of the contents of its stomach,- that final court of appeal. Through pressure brought to bear upon Congress by the American Ornithologists' Union, the Department of Agriculture was authorized in I 885 to spend a ridiculously small sum to learn the positive economic value of birds to us, a branch of scientific research now included under the Division of Biological Survey. Until that year all the scientific work that was done in this line could have been recorded in a very small volume indeed.

\section{A GENERAL WHITEWASHING}

As might have been expected, when the white search-light of science beats upon the birds, none, not even the crow, appears as black as he has been painted. Only a few culprits among the hawks and owls, and only one little sinner not a bird of prey, stand convicted and condemned to die. When it came to a verdict on the English sparrow, after the most thorough and impartial trial any bird ever received, every thumb, alas! was turned down. But having proven itself fittest to survive in the struggle for existence after ages of competition with the birds of the Old World, being obedient to nature's great law, it will defy man's legislation to exterminate it. Toilers in our over-populated cities, children of the slums, see at least one bird that is not afraid to live among them the year around. 


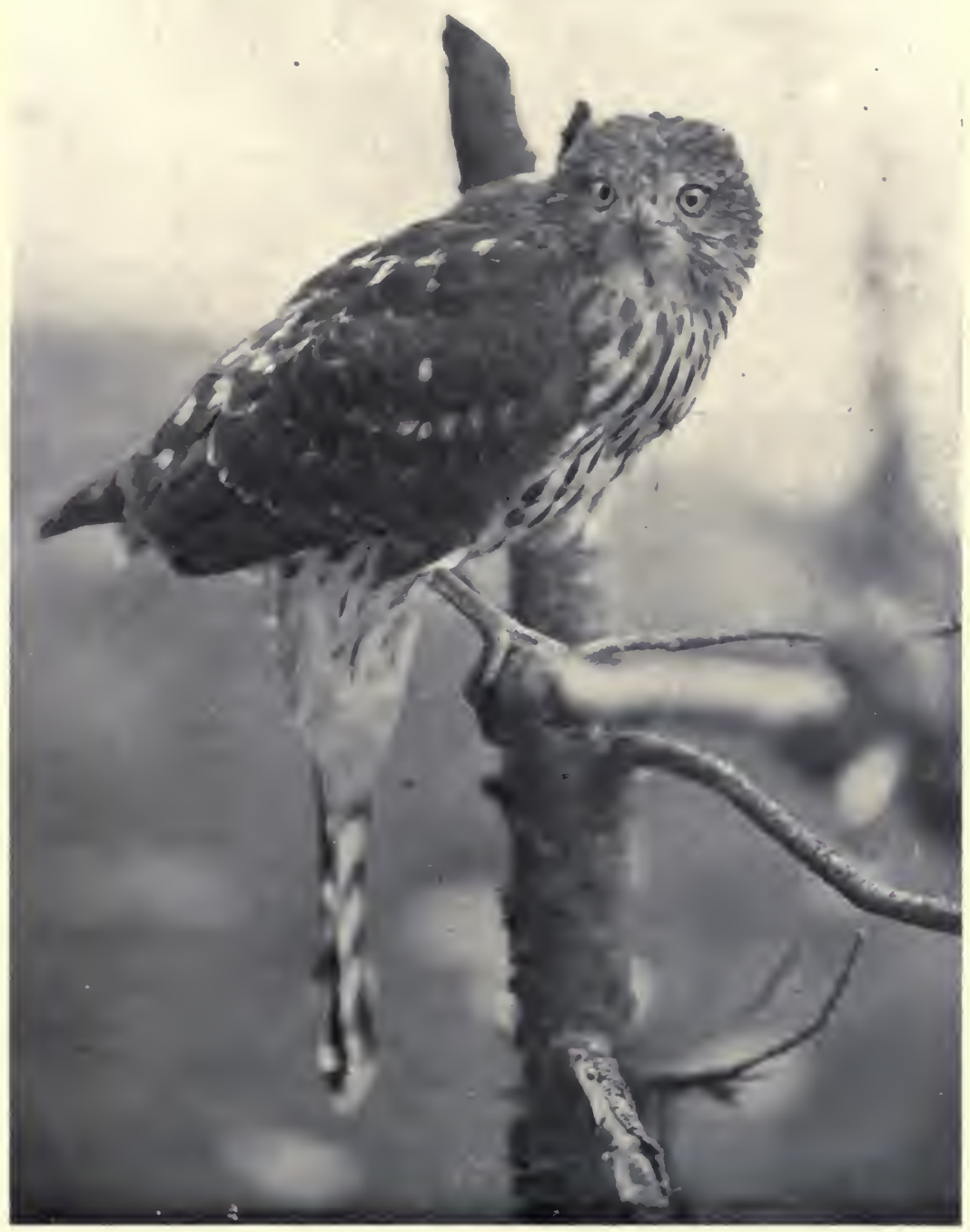

A much maligned ally of the farmer - the Red-shouldered Hawk 



\section{What Birds Do for Us}

One of the first good effects of the Government's scientific investigation of birds, and the consequent whitewashing of bird characters that ensued, was the withdrawal of bounties by many states. Pennsylvania, for instance, woke up to realize that her notorious "scalp act" had lost her farmers many millions of dollars through the ravages of field mice, because the wholesale slaughter of all hawks and owls, regardless of their food and habits, had been systematically encouraged. A little knowledge on the part of legislators, backed by an immense amount of popular ignorance and prejudice against all of the socalled birds of prey, proved to be a very dangerous thing. Even better than the withdrawal of bounties is the action taken by many states to protect the birds. Instead of laying stress upon only the apparent evil in nature, as undeveloped pagans did, we are at last putting the emphasis where it rightly belongs,-upon the good.

\section{THE PARTITION OF APPETITES}

Whoever takes any notice of the birds about us cannot fail to be impressed with the regulation of that department of nature's housekeeping entrusted to them. The labor is so adjusted as to give to each class of birds duties as distinct as a cook's from a chambermaid's. One class of tireless workers is bidden to sweep the air and keep down the very small gauzy-winged pests such as mosquitoes, gnats, and midges. Swallows dart and skim above shallow water, fields, and marshes; purple martins circle about our gardens; swifts around the roofs of our 


\section{How to Attract the Birds}

houses, night-hawks and whippoorwills through the open country, all plying the air for hours at a time. Some, which fly with their mouths open, need not pause a moment for refreshments.

On distended upper branches, preferably dead ones, on fence rails, posts, roofs, gables and other points of vantage where no foliage can impede their aerial sallies, sit kingbirds, pewees, phœbes, and kindred dusky, inconspicuous flycatchers, ready to launch off into the air the second an insect heaves in sight, snap it up with the click of a satisfied beak, then return to their favorite look-out and patiently wait for another. This class of birds keeps down the larger flying insects. For generations the kingbird has been condemned as a destroyer of bees. Rigid investigation proves that he eats very few indeed, and those mostly drones. On the contrary, he destroys immense numbers of robber-flies or bee-killers, one of the worst enemies the bee farmer has. The mere fact that the kingbird has been seen so commonly around apiaries was counted sufficient circumstantial evidence to condemn him in this land of liberty. But after a fair trial it was found that ninety per cent of his food consists of insects chiefly injurious : robber-flies, horse-flies, rose chafers, clover weevils, grasshoppers, and orchard beetles among others.

\section{THE CARE OF FOLIAGE}

To such birds as haunt the terminal twigs of trees and shrubbery-the warbler tribe and the vireos, chiefly-was assigned the duty of cleaning the foliage on the ends of the branches, where many kinds of 


\section{How to Attract the Birds}

has snatched a hasty lunch in any given place, the vireo can follow him and find a square meal to be enjoyed at leisure.

But vireos and warblers, which are smaller than sparrows, however efficient as destroyers of the lesser insects, would be powerless to grapple with the lar-

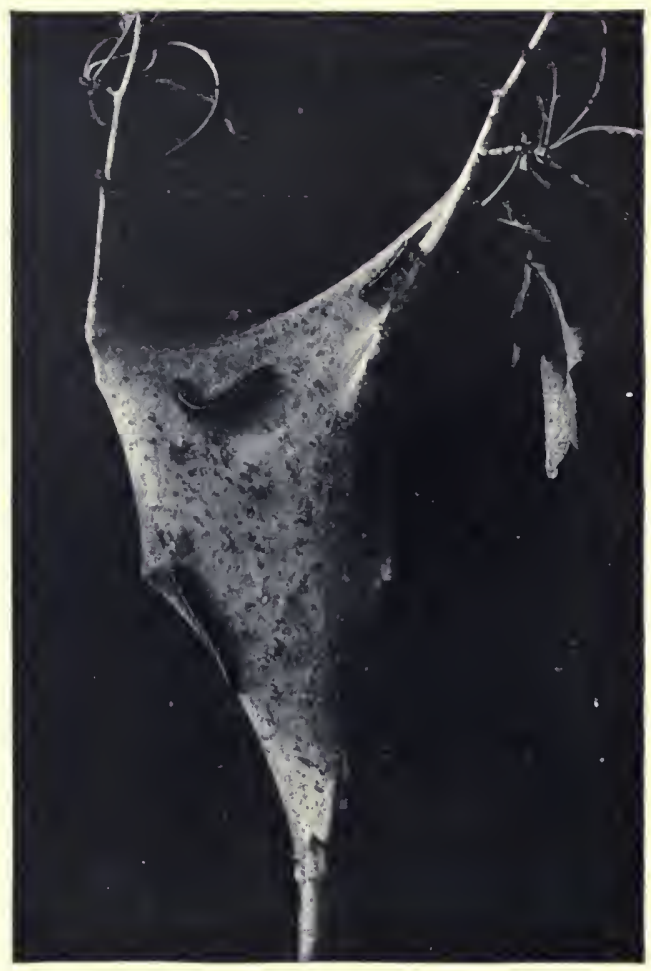

A feast of tent caterpillars for the cuckoo ger pests found in the same places. Accordingly, another gang of larger feathered workers helps take care of the foliage for that most thorough of housekeepers, Dame Nature. Hidden among the foliage of trees and shubbery, an immense army of feathered workers - many of our most beautiful birds and finest songsters among them-serve her without hire, and during longer working hours than any trades-union would allow. Thrushes, bluebirds, robins, mockingbirds, orioles, catbirds, thrashers, wrens, and tanagers - these and many others keep up a lively 


\section{What Birds Do for Us}

insect hunt throughout a long sojourn among us, coming when the first insects emerge in the spring and not wholly giving up the chase until the last die or become dormant with the coming of winter. What could a little warbler do with tent caterpillars, for example? But slim, large cuckoos glide among the leafy branches and count them-.

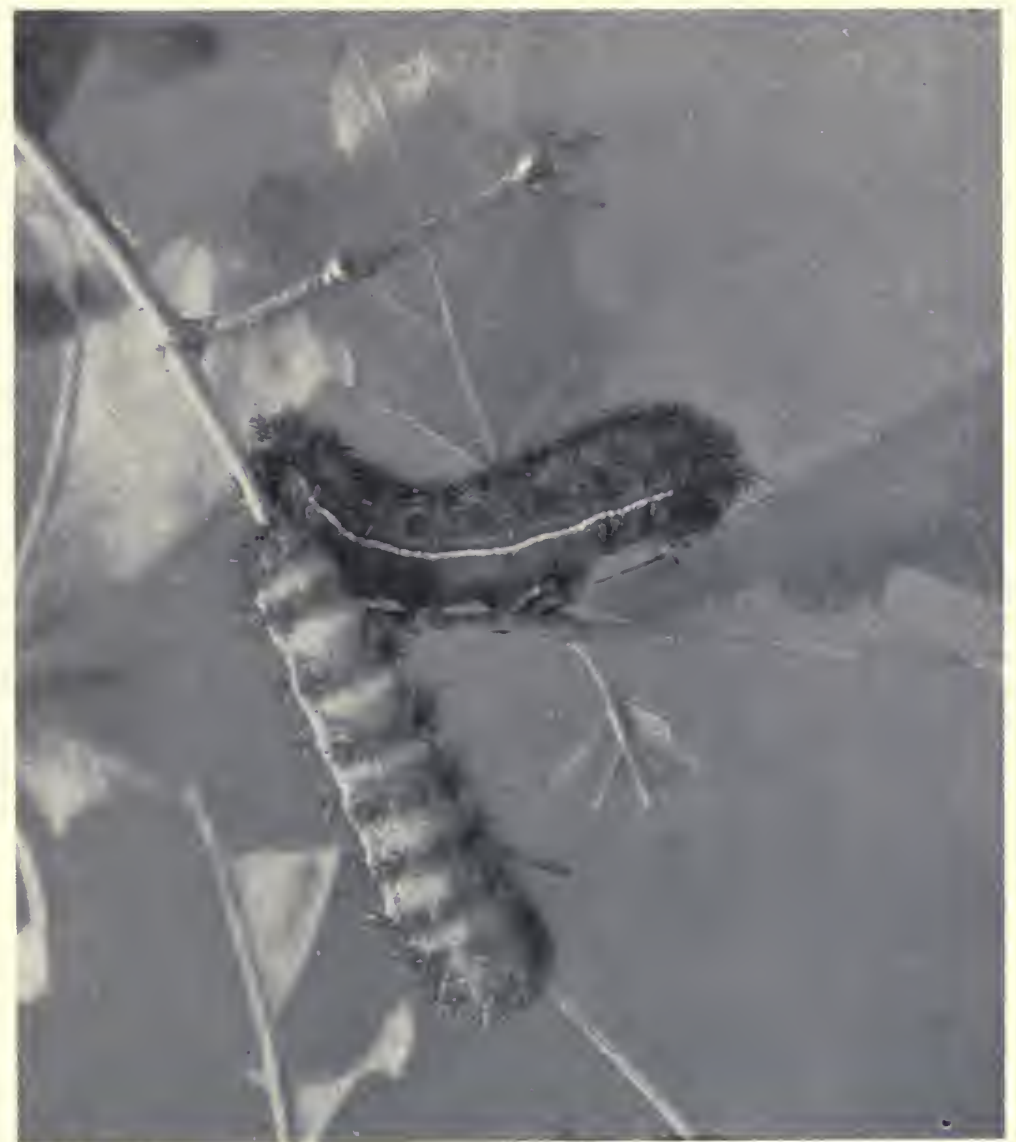

"Most birds will not touch the hairy kind" 


\section{How to Attract the Birds}

selves lucky to enter a neighborhood infested by them. The sudden appearance of a new insect pest often attracts large numbers of birds not commonly seen in the neighborhood.

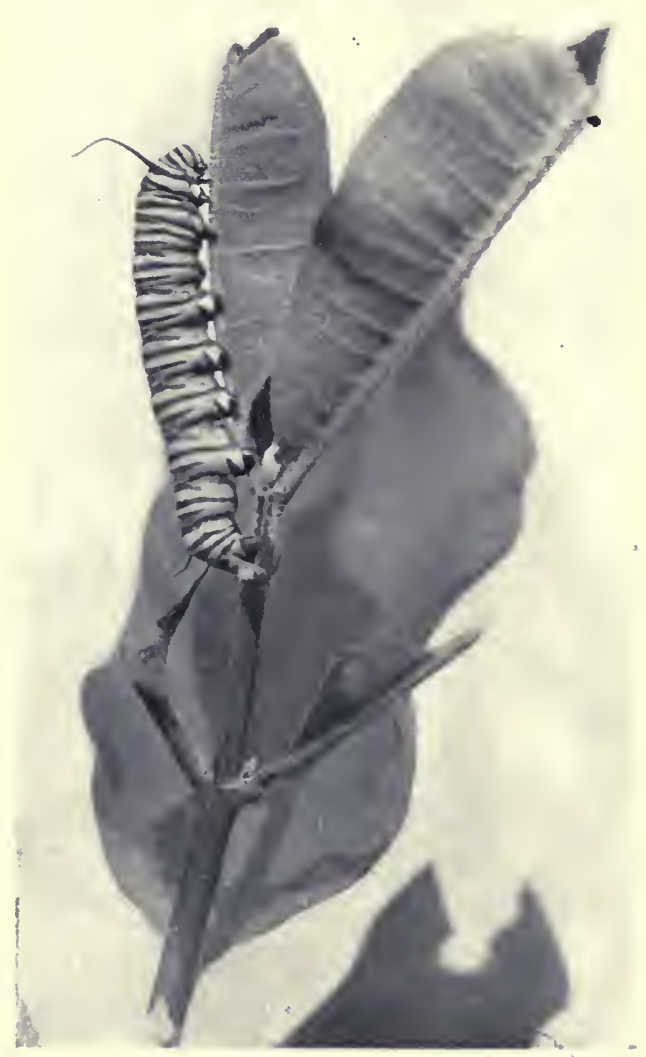

An important item on the Baltimore Oriole's bill of fare (smooth Caterpillar) If dead or mutilated larvæ of tent caterpillars are seen near the torn tent it was probably opened by an oriole, for the cuckoo does his work more thoroughly, leaving no remains. The black-billed cuckoo has been an invaluable ally of the farmers in their herculean task of destroying the gypsy moth, an alarming pest which, although only recently introduced from Europe, has already laid waste large sections of New England. The stomach of a single yellow - billed cuckoo examined contained two hundred and seventeen fall webworms! Hairs have been considered a means of 


\section{What Birds Do for Us}

protection adopted by many caterpillars. Most birds will not touch the hairy kind. But cuckoos are not so fastidious. The walls of their stomachs are sometimes as closely coated with hairs as a gentleman's beaver hat. Caterpillars are also the most important item on the Baltimore oriole's bill of fare, of which eighty-three per cent is insect food gleaned among the foliage of trees. Click beetles, which infest every kind of cultivated plant, and their larvæ, known as wire-worms, destroy millions of dollars' worth of farm produce every year. Now, there are over five hundred species of them in North America, and the oriole, which eats them as a staple and demolishes very many other kinds of beetles, wasps, bugs, plant-lice, craneflies, grasshoppers, locusts, and spiders, should win opinions as golden as his feathers for this benefaction alone. It has been said that were all the insects to perish, all the flowers would perish too, which is not half so true as that were all the birds to perish men would speedily follow them. At the end of ten years the insects, unchecked, would have eaten every green thing off the earth!

THE BIRDS THAT HAVE CHARGE OF THE BARK

For obvious reasons, then, many crawling insects hide themselves under the scaly bark of trees or in holes laboriously tunneled in decaying wood; others deposit their eggs in such secret places. When they die a natural death at the close of summer it is with the happy delusion that the next generation of their species, sleeping in embryo, is perfectly safe. But see how long it takes a woodpecker to eat a hundred 


\section{How to Attract the Birds}

insect eggs and empty a burrow of every grub in it ! Inspecting each crevice where moth or beetle might lay her eggs, he works his way around a tree from bottom to top, now stopping to listen for the stirring of a borer under the smooth, innocent-looking bark, now tapping at a suspicious point and quickly drilling a hole where there is a prospect of heading off his victim. Using his bill as a chisel and mallet and his long tongue as a barbed spear to draw the grub from its nethermost hiding place, he lets nothing escape him. Boring beetles, tree-boring caterpillars, timber ants, and other insects which are inaccessible to other birds, must yield their reluctant bodies to that merciless barbed tongue. Our little friend downy and the hairy woodpecker, the most beneficial members of the family, the flicker that descends to the ground to eat ants, the red-headed woodpecker that intersperses his diet with grasshoppers, even the much-maligned sapsucker that pays for his intemperate drinks of freshly drawn sap by eating ants, grasshoppers, flies, wasps, bugs, and beetles,to these common woodpeckers and to their less neighborly kin, more than to any other agency, we owe the preservation of our timber from hordes of destructive insects.

But acknowledgment of this deep obligation must not cause us to overlook the nuthatches, brown creepers, chickadees, kinglets, and such other helpers that keep up quite as tireless a search for insects on the tree trunks and larger limbs as the more perfectly equipped woodpeckers. "In a single day a chickadee will sometimes eat more than four hundred eggs of the apple plant-louse," says Professor 


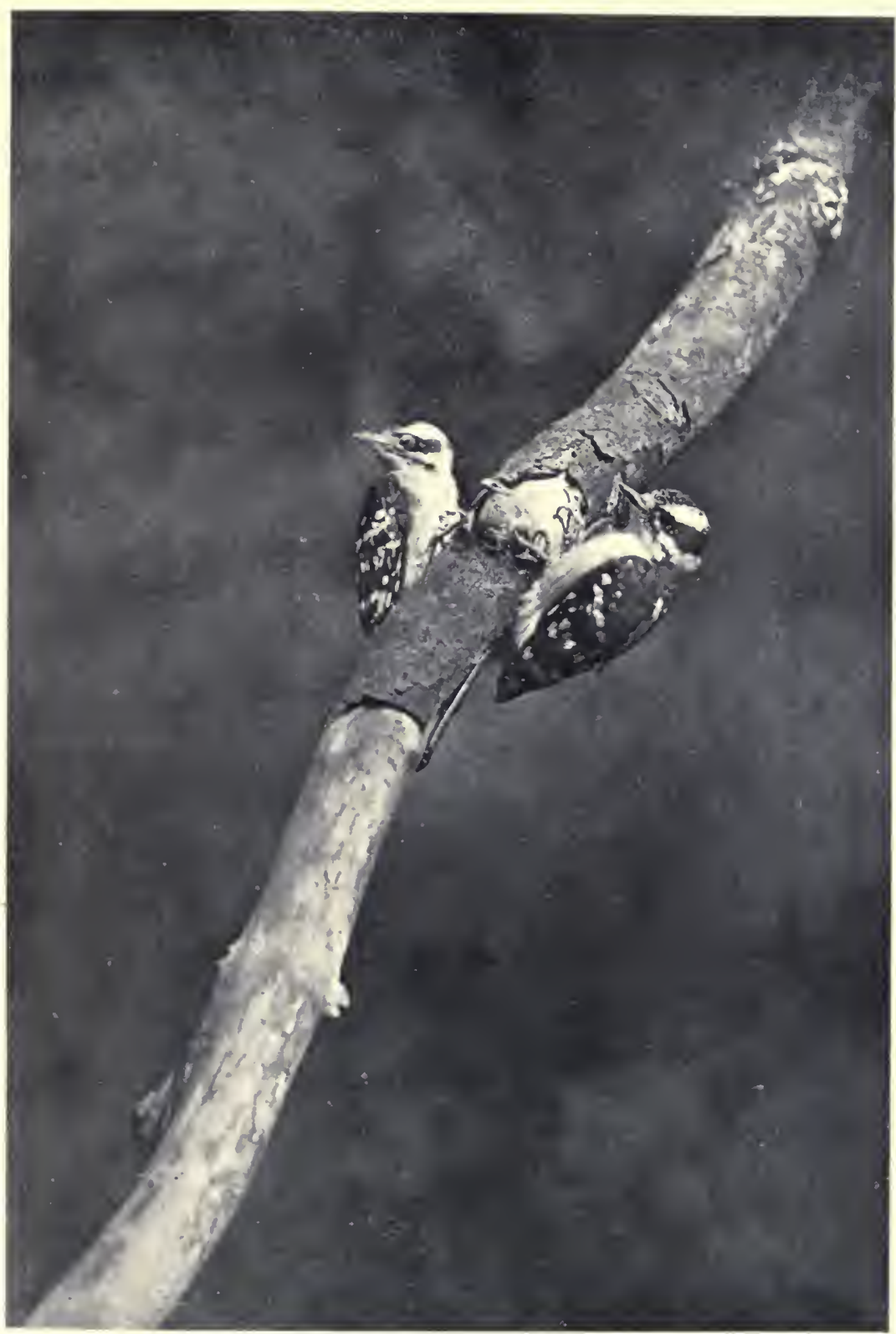

Preservers of timber : Downy Woodpeckers 



\section{What Birds Do for Us}

Clarence Moores Weed, "while throughout the winter one will destroy an immense number of the eggs of the canker-worm."

\section{CARETAKERS OF THE GROUND FLOOR}

Hidden in the grasses at the foot of the trees, among the undergrowth of woodland borders, under the carpet of last year's leaves, and buried in the ground itself, are insect enemies whose name is legion. Among the worst of them are the white grubs-the larvæ of May beetles or June bugs-and the wireworms which attack the roots of grasses and the farmers' grain'; the maggots of crane-flies which do their fatal work under cover of darkness in the soil; root- and crown-borers which destroy annually fields of timothy, clover, and herds-grass; grasshoppers, locusts, chinch bugs, cutworms and army worms that have ruined crops enough to pay the national debt many times over.

But what a hungry feathered army rushes to their attack! And how much larger would that army have been if, in our blind stupidity or ignorance, we had not killed off billions of members of it!

Some habitual fruit- or seed-eating birds of the trees descend to the ground at certain seasons, or when an insect plague appears, changing their diet to suit nature's special need; others "lay low" the the year around, waging a perpetual insect war. First in that war stands the meadow-lark. It is estimated that every meadow-lark is worth over one dollar a year to the farmers, if only in consideration of the grasshoppers it destroys; and as insects constitute 


\section{How to Attract the Birds}

seventy-three per cent of its diet, the remainder being seeds of weeds chiefly, the farmer might as well draw money out of the bank and throw it in the sea as to allow the meadow-lark to be shot; yet it

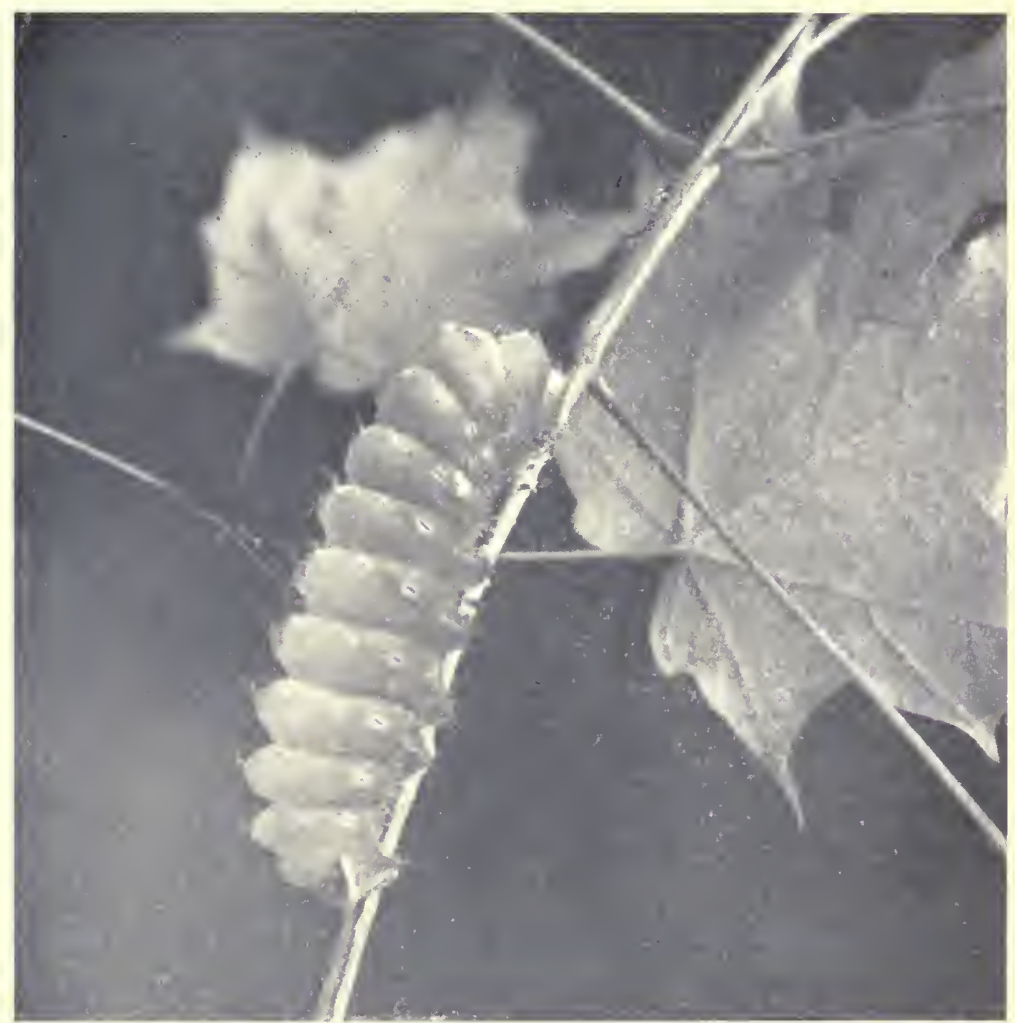

An appetizing dinner

has long been classed among game birds - a target for gunners.

"The average annual loss which the chinch bug causes to the United States cannot be less than twenty million dollars," says Dr. L. O. Howard, of 


\section{What Birds Do for Us}

the Department of Agriculture. "It feeds on Indian corn and on wheat and other small grains and grasses, puncturing the stalks and causing them to wilt." Incalculable numbers of this pest are eaten every season by Bob Whites, or quail, which, it will be seen, are perhaps as valuable to the American people when roaming through our grain fields as when served on toast to our epicures. Blackbirds, crows, robins, native sparrows, chewinks, oven-birds, brown thrashers, ground warblers, woodcock, grouse, plovers, and the yellow-ivinged woodpeckers or flickers, which feed on ants (whose chief offense is that they protect aphides or plant lice to "milk" them) - these, and many other birds contribute to our national wealth more than the wisest statistician could estimate. Many old farmers will wish at least the crow or the blackbird removed from this white list, but scientific experts have proved that the workman is worthy of his hire - that the birds which destroy enormous numbers of white grubs, army worms, cutworms and grasshoppers in the fields are as much entitled to a share of the corn as the horse that plows it or the ox that treads it out. The evil results following a disturbance of nature's nice balances rest on no scientific theories but on historic facts. Protective bird laws, which very quickly increase the insect police force, add many million dollars annually to the permanent wealth not only of such enlightened states as have adopted them, but to the country at large, for birds, like the rain, minister to the just and the unjust. And the rising generation of farmers is the first to be taught this simple economic fact! 


\section{WEED DESTROYERS}

Weeds have been defined as plants out of place, and agriculture as an everlasting war against them. What natural allies has the pestered farmer?

Happily, the sparrows and finches, among the most widely distributed, prolific and hardy of birds, are his constant co-workers, some members of their large clan being with him wherever he may live every day in the year. Nearly all, it is true, vary

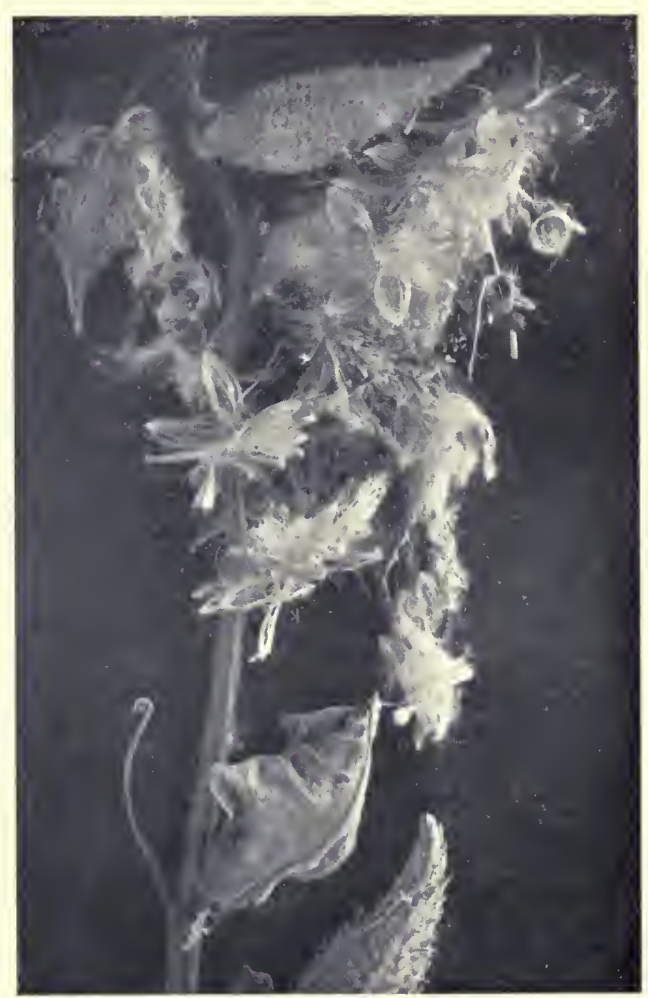

A tempting lunch. - Milk-weed seeds for the finches their diet with insects, but surely they are no less welcome on that account!

"Certain garden weeds produce an incredible number of seeds," says Dr. Sylvester Judd, of the Biological Survey. "A single plant of one of these species may mature as many as a hundred thousand seeds in a season, and if unchecked would produce in the spring of the 
third year ten billion plants." With these figures in mind, it is easy to account for the exceedingly rapid spread of certain weeds from the Old World -daisies and wild carrot, for example - of comparatively recent introduction here. The great majority of weeds being annuals, the parent plant dying after frost or one season's growth and the species living only in embryo during the remainder of the year, it follows that seed-eating birds are of enormous practical value. Even the despised English sparrows do great good as weed destroyers -almost enough to tip the scales of justice in their favor. In autumn, what noisy flocks of the little gamins settle on our lawns and clean off seeds of crab-grass, dandelion, plantain, and other upstarts in the turf! The song sparrow, the chipping sparrow, the white-throated sparrow, and the goldfinch are glad enough to follow after their English cousin and get out the dandelion seeds exposed after he cuts off several long, protecting scales of the involucre. Because of his special preference, however, the little black and yellow goldfinch, an unequaled destroyer of the composite weeds, is often called the thistle-bird. The few tender sparrows which must winter in the south are replaced in autumn by hardier relatives, whose feeding grounds at the far north are buried under snow; by juncos, snowflakes, longspurs, redpolls, grosbeaks, and siskins, all of which are busy gleaners among the plow furrows in fallow land, and the brown weed-stalks that flank the roadsides or rear themselves above the snowy fields. In enumerating the little weeders that serve us without so much as a "thank you" - and fifty dif- 


\section{How to Attract the Birds}

ferent birds are on this list-we must not forget the horned lark, chewink, blackbirds, cowbird, grackles, meadow-lark, bobolink, ruffed grouse, Bob White, and the mourning dove.

Even the most sluggish birds-and some of the finch tribe have a reputation for being that-are fast livers compared with men. Their hearts beat twice as fast as ours; we should be feverish were our blood less hot; therefore, the quantity of food required to sustain such high vitality, especially in winter, is relatively enormous. A tree sparrow will eat one hundred seeds of pigeon-grass at a single meal, and a snowflake, observed in a Massachusetts garden one February morning, picked up over a thousand seeds of pigweed for breakfast.

\section{BUSINESS CO-PARTNERSHIPS}

In view of the enormous amount of work certain birds are capable of doing for the farmers, how many take any pains to secure their free services continuously; to get help from them as well as from the spraying machine and insect powder on which so much time and money are spent annually? The truth is that very few farmers indeed realize the true situation; therefore the intelligent, the obvious thing to be done is generally neglected.

One of the most successful fruit-growers in Georgia, whose luxuriant orchard and luscious peaches are famous throughout the market, entered some time ago into a systematic, business-like understanding with a number of birds whose special appetites for special insect pests make them invaluable partners. 


\section{What Birds Do for Us}

Up and down through the long avenues of trees he erected poles from twenty to thirty feet high, and from them swung gourds for the purple martins to nest in, because he has found this bird his chief ally in keeping down the cuculio beetle, the most destructive foe, perhaps, the fruit-grower has to fight. Through its attack alone the value of a single peach

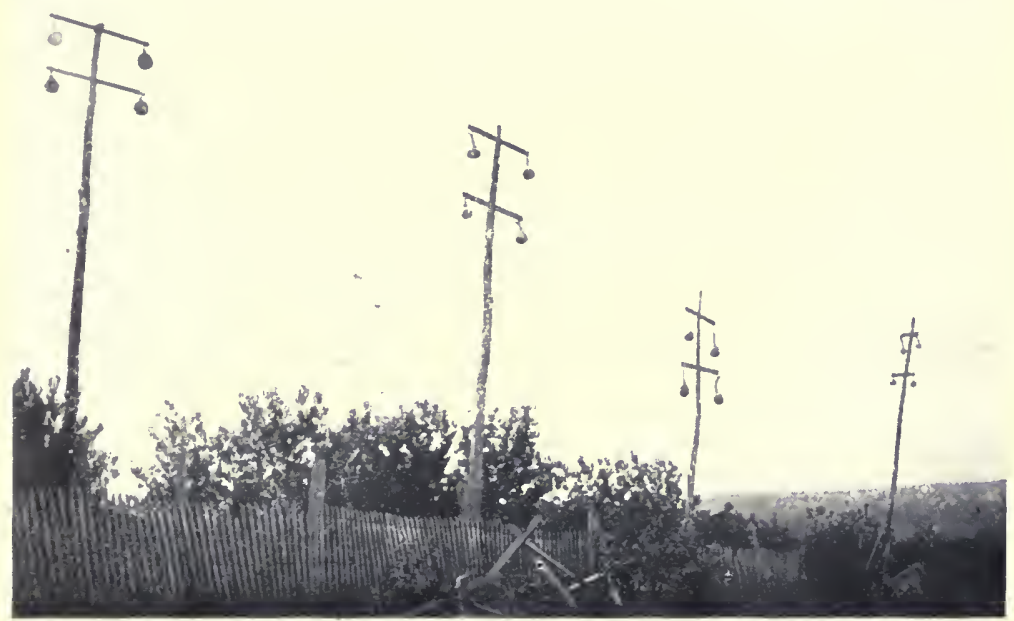

How a successful peach grower in Georgia makes the purple martins work for him

orchard has been reduced from ten thousand dollars to nothing in three weeks! The damage this little beetle does to American fruit-growers annually amounts to many millions of dollars. Just when the martins return from the tropics, it is emerging from its winter hibernation. And when the nuptial flight of the curculio and the shot-hole borer and of the root-borer moth occurs, it ought to be obvious to every fruit grower that he cannot have too many insectivorous 


\section{How to Attract the Birds}

birds about. Bluebirds, which readily accept invitations to nest in boxes placed on poles and trees, destroy immense numbers of insects taken from the trees, ground, and air. In the Georgia orchard referred to, titmice, chickadees, and nuthatches are attracted by raw peanuts placed in the trees and scat-

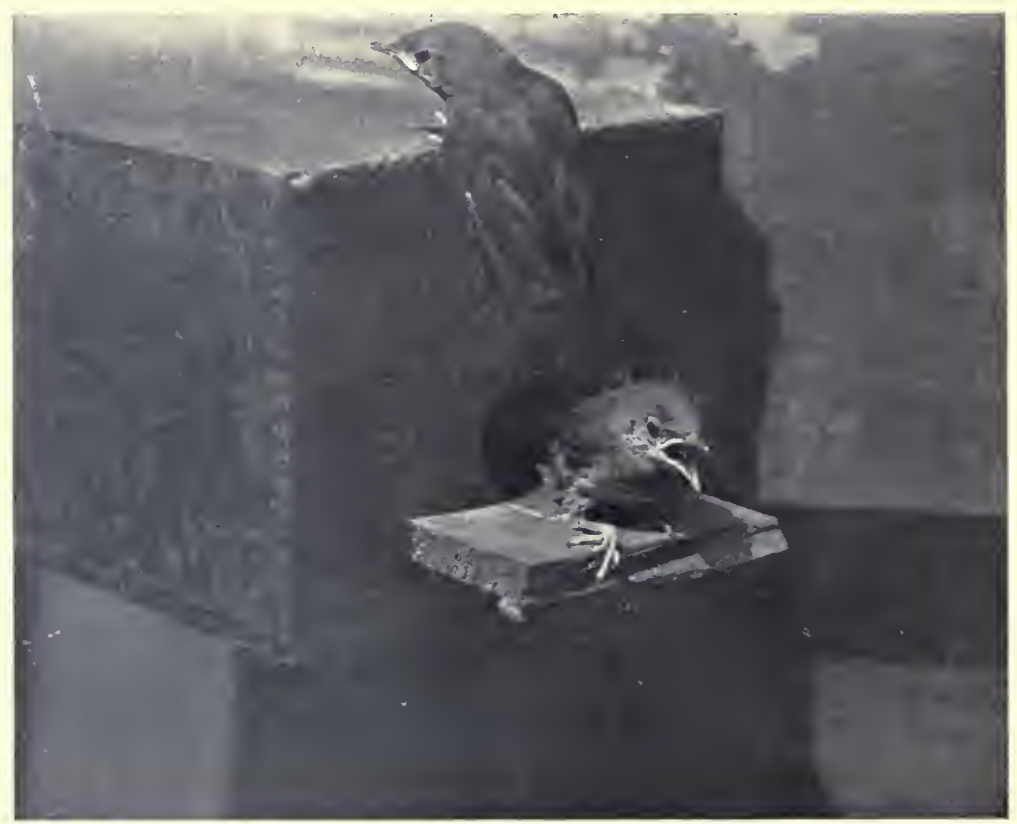

Junior partners: young house-wrens almost ready to earn their own living tered over the ground. Once these favorite nuts were discovered, this family of birds likewise joined the firm which, with the addition of the owner of the estate, now consists of purple martins, barn swallows, chimney-swifts, bluebirds and wrens. Of course they have numerous assistants that come and go, but these are the recognized partners, both full-fledged and juniors, with homes on the place. And all draw 
enormous dividends from it in that unique and happy manner which greatly increases the cash revenues of the business. Perhaps the junior partners, the fledglings, with appetites bigger than their bodies (for many eat more than their weight of food

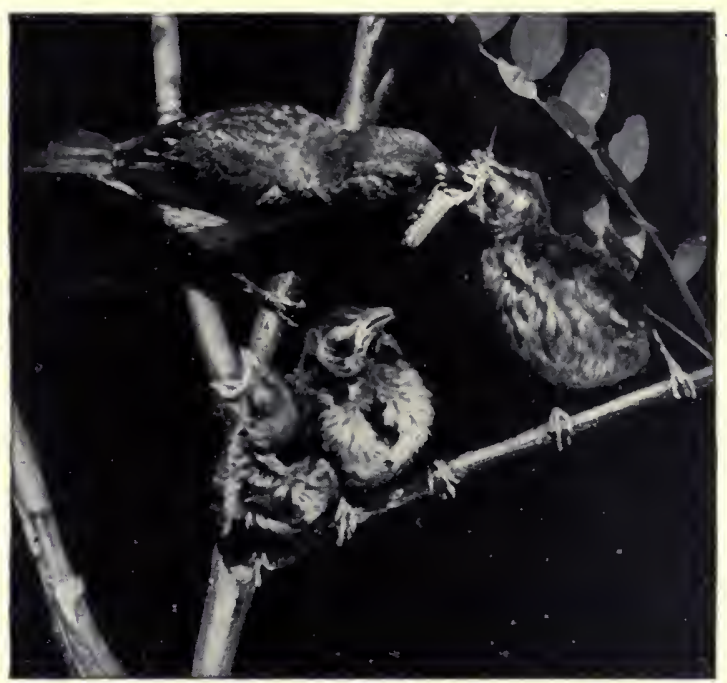

"An Indigo Bunting mother does not hesitate to ram a large grasshopper down her small baby's throat after she has nipped off the wings"

every twenty-four hours), are of greater value than the seniors. Even seed-eating birds, as we have seen in a previous chapter, feed insects to their nestlings: an indigo bunting mother does not hesitate to ram a very large grasshopper down her very small baby's throat after she has nipped off the wings.

\section{PARTNERSHIPS IN NATURE}

Just as many insects have resorted to curious and ingenious devices to avoid the birds' attention, so 


\section{How to Attract the Birds}

many trees, shrubs, and plants, with ends of their own to be gained, take great pains to attract it. Some insects mimic with their coloring that of their surround-

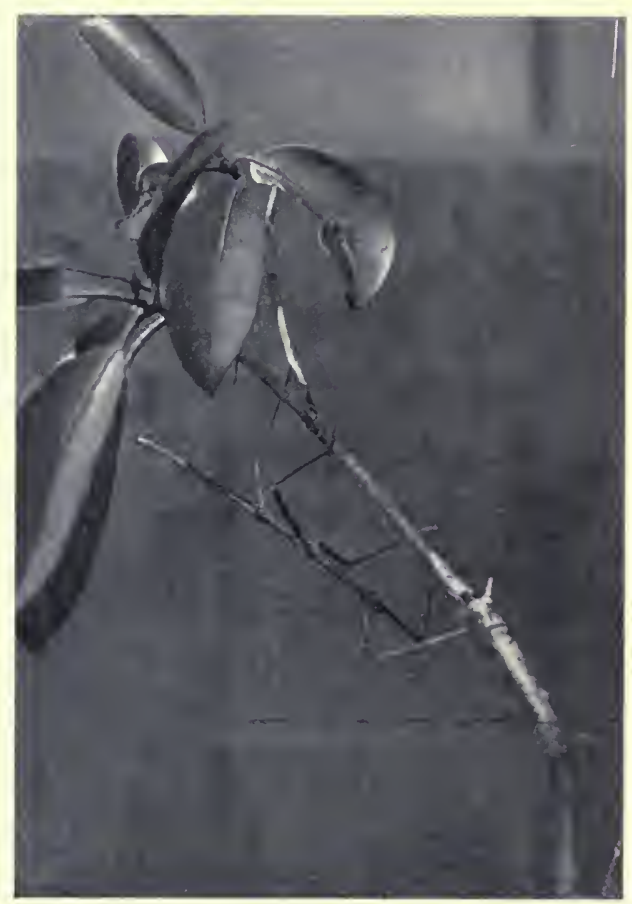

A slim enough dinner for any bird that discovers it.-The walking stick ings: one must look sharp before discovering the glaucous green worm on the glaucous green nasturtium leaf. Some, like the milkweed butterfly, secrete disagreeable juices to repel the birds, and other butterflies, which secrete none, fool their foes by bearing a superficial $r$ es e mblance to it. Others, like the walking-stick, assume a form that can scarcely be distinguished from the objects it frequents. With what pains does the caterpillar draw together the edges of a leaf and hide within it, sleeping until ready to emerge into its winged stage, if by chance a pair of sharp eyes does not discover it at the beginning of its nap, and a sharper beak tear it ruthlessly from the snug cradle! Children who 


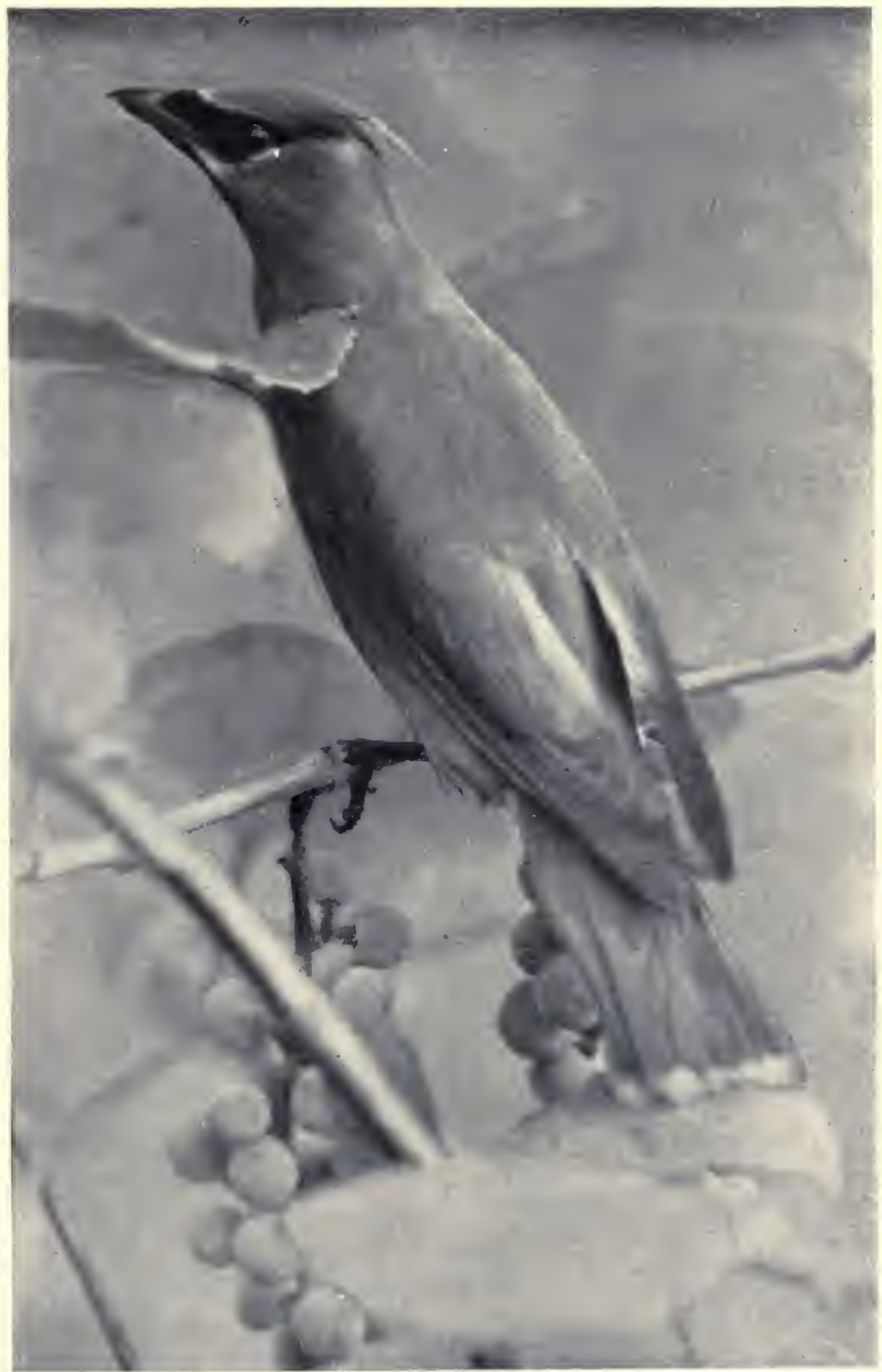

"For how much of earth's beauty are not birds, the seed carriers, responsible!" Cedar bird in wild-grape vine 

gather cocoons in the autumn are often disappointed to find so many already empty. They forget that thousands of hungry migrants have been out hunting every morning before they left their beds. No cradle yet woven is too tough for some bird to tear open for the luscious, fat morsel within. To the Baltimore oriole looking for a dinner, the strong cocoon of the great cecropia moth yields one as readily as another; and I have watched an orchard oriole that brought her young family to feast in

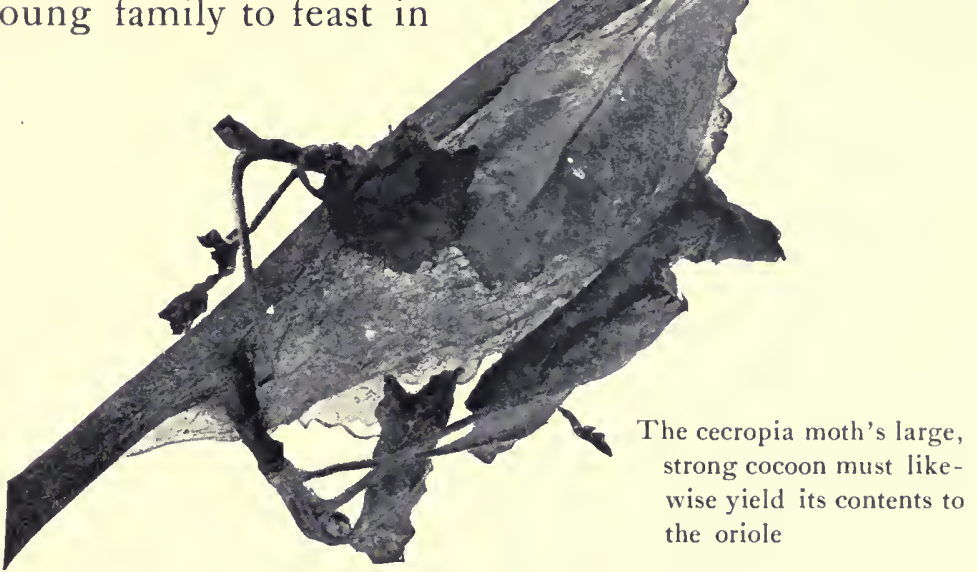

a tamarix bush in the garden, pick forty-seven basket-worms from their cleverly concealed baskets in fifteen minutes.

But how the bright berries, hanging on the dogwood, mountain ash, pokeweed, choke-cherry, shadbush, partridge vine, wintergreen, bittersweet, juniper, Virginia creeper, and black alder, cry aloud to every passing bird, "EAT ME," like Alice's marmalade in Wonderland! Many plants depend as certainly on the birds to distribute their seeds as on 


\section{How to Attract the Birds}

bees and other insects to transfer the pollen of their flowers. It is said that the cuckoo-pint or spotted arum of Europe, a relative of our jack-in-the-pulpit, actually poisons her messengers carrying seed, because the decaying flesh of the dead birds affords the most nourishing food for her seed to germinate in. Happily we have no such cannibalistic pest here. Our wild trees, shrubbery, plants, and vines are honorable partners of the birds. They feed them royally, asking in return only that the undigested seeds or kernels which pass through the alimentary canal uninjured may be dropped far away from the parent plant, to found new colonies. For how much of the earth's beauty are not birds, the seedcarriers, responsible!

Up-to-date-farmers who wish to protect their cultivated fruits have learned that birds actually have the poor taste to prefer wild ones, and so they plant them on the outskirts of the farm, along walls and fences. They have also learned that many birds puncture grapes and drink fruit juice simply because they are thirsty. Pans kept filled with fresh water compete successfully with the grape arbor.

\section{SAINTS AND SINNERS}

Hawks and owls may be so labeled, yet it would be difficult, if not impossible, to convince some people that there is a saint in the group. There is an instinctive popular hatred of every bird of prey, - a hatred so unreasoning and unrelenting that it is wellnigh impossible to secure legislation to protect some of the farmers' most beneficial friends. After con- 


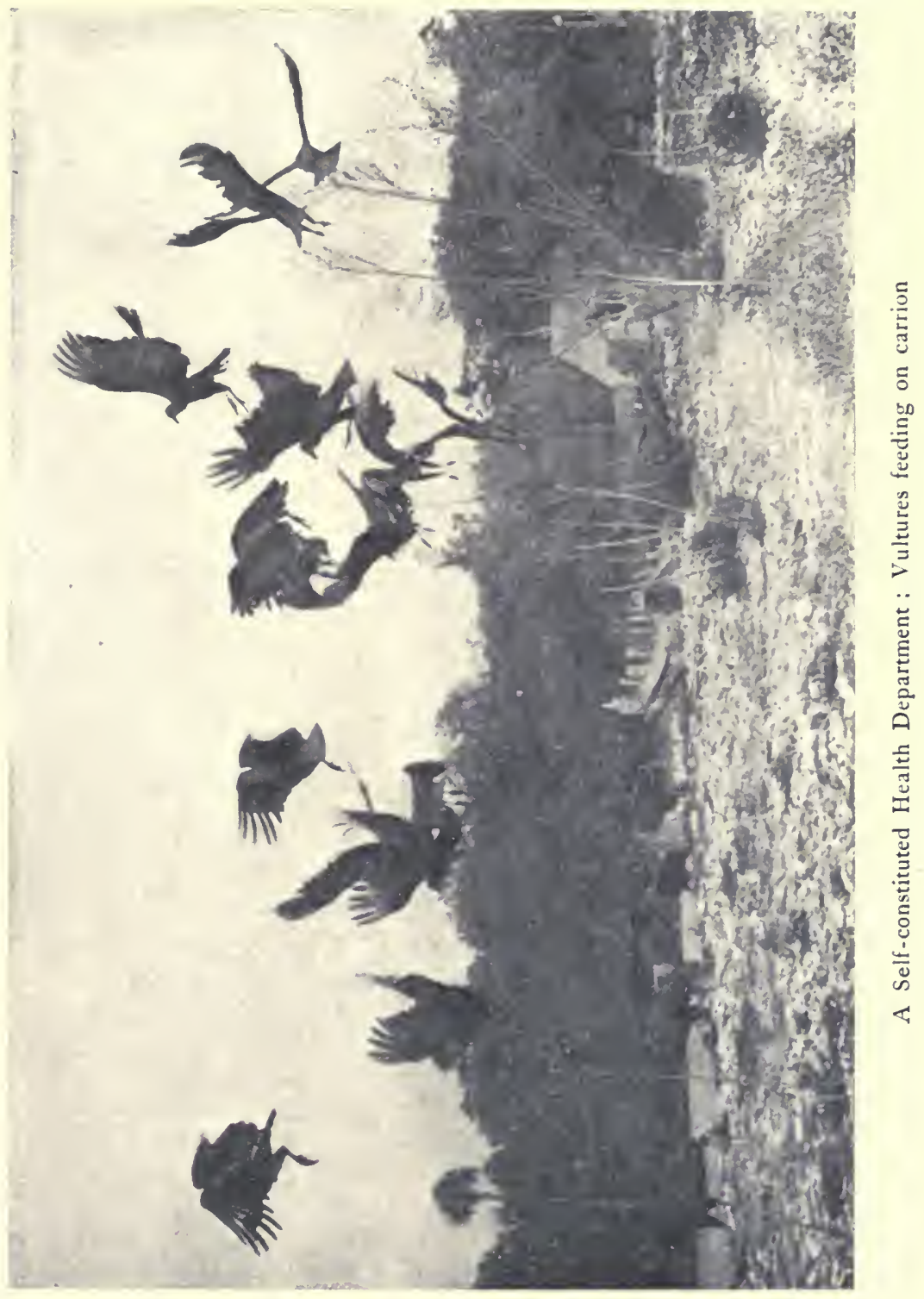


demning the duck hawk for its villainies upon our wild water-fowl, and that powerful brigand, the goshawk, for audaciously carrying off full-grown poultry, ruffed grouse and rabbits, and Cooper's hawk, a deep-dyed chicken stealer, whose aggregate misdeeds are greater than any others (simply because his species is the most numerous), and his smaller prototype, the sharp-shinned hawk for destroying little chickens and song-birds, Dr. Fisher, who made an exhaustive study of hawks and owls for the Government, recommends clemency toward all the others. He investigated forty birds of prey found within our borders.

"It would be just as rational to take the standard for the human race from highwaymen and pirates as to judge all hawks by the deeds of a few," he says.

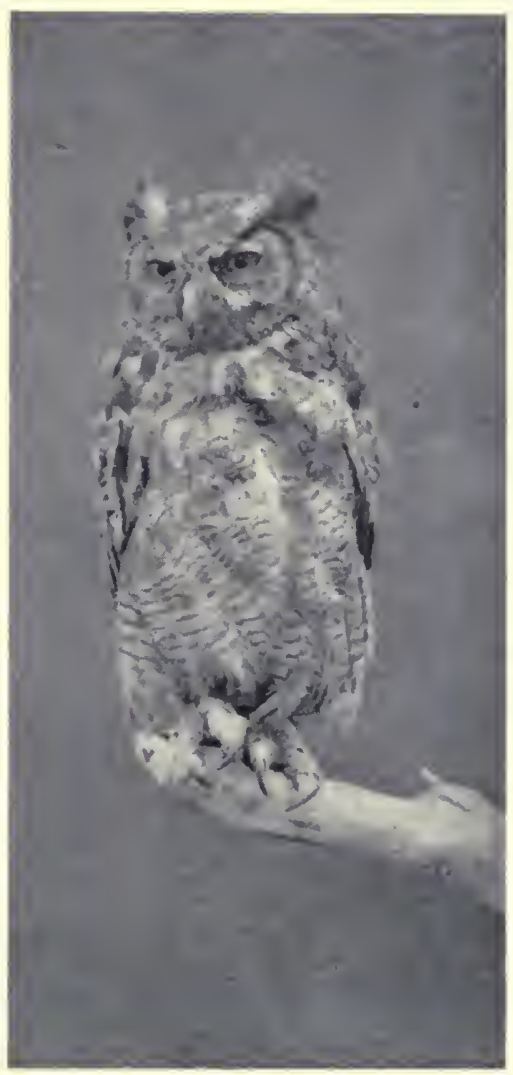

A Dr. Jekyll and Mr. Hyde: the horned owl

"Even when the industrious hawks are observed beating tirelessly back and forth over the harvest fields and meadows, or the owls are seen at dark 


\section{How to Attract the Birds}

flying silently about the nurseries and orchards, busily engaged in hunting the voracious rodents which destroy alike the grain, produce, young trees, and eggs of birds, the curses of the majority of farmers and sportsmen go with them, and their total extinction would be welcomed. How often are the services to man misunderstood through ignorance! The birds of prey, the majority of which labor day and night to destroy the enemies of the husbandman, are persecuted unceasingly, while that gigantic fraud - the house cat-is petted and fed and given a secure shelter from which it may emerge to spread destruction among the feathered tribe. The difference between the two can be summed up in a few words: Only three or four birds of prey hunt birds when they can procure rodents for food, while a cat seldom touches mice if she can procure birds or young poultry. A cat has been known to kill twenty young chickens in a day, which is more than most raptorial birds destroy in a lifetime."

Hawks and owls admirably supplement each other's work. One group hunts while the other sleeps. The owls usually remain in a chosen neighborhood through the winter, while the hawks go south. We are never left unprotected. In consideration of the overwhelming amount of good these unthanked friends do us, can we not afford to be to their faults a little blind?

\section{A VOLUNTEER HEALTH DEPARTMENT}

In the southern states, Cuba, and the adjacent islands, the great dark vultures that go sailing high 


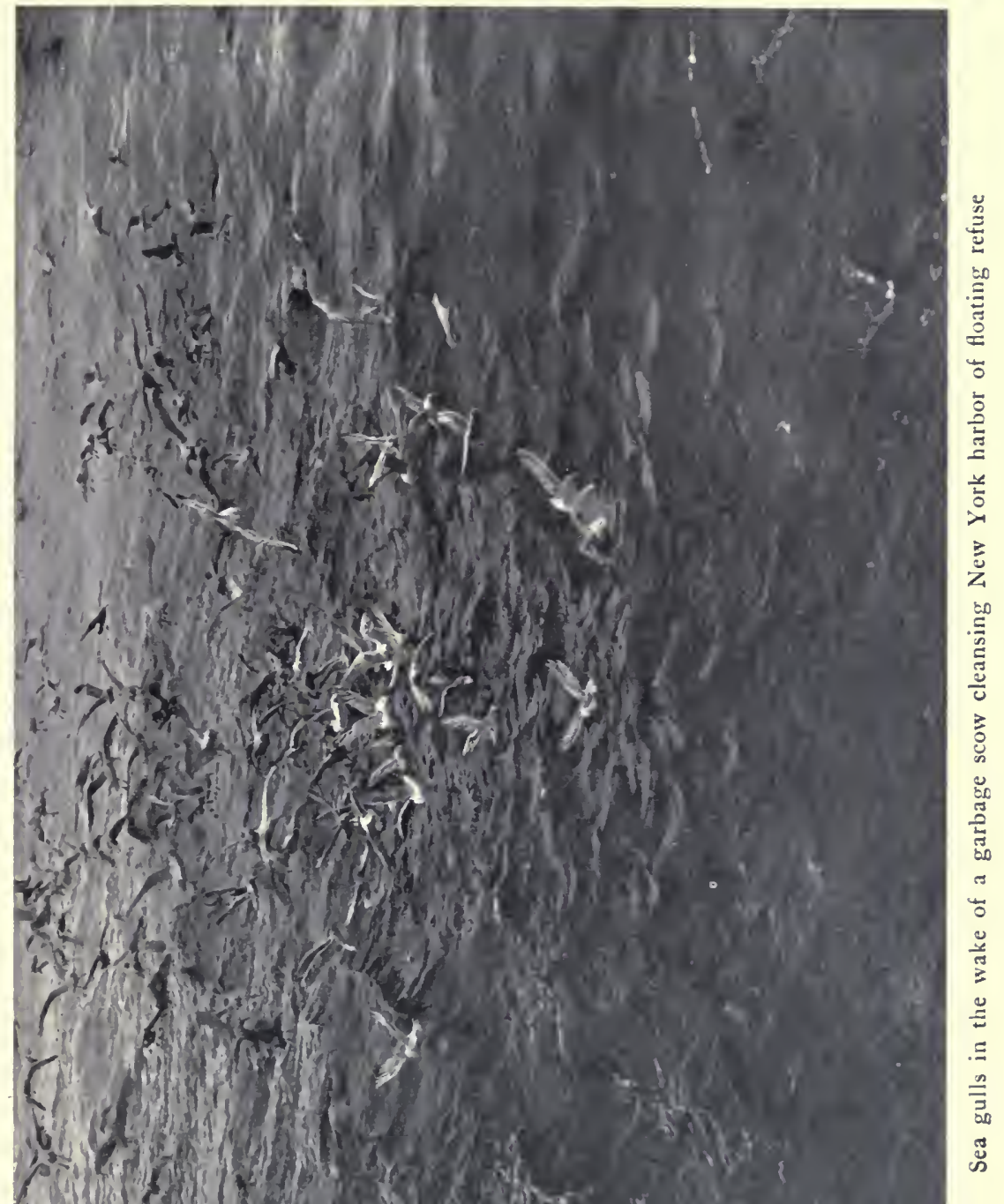



in air express the very poetry of motion; but surely their terrestrial habits have to do with the very prose of existence, for self-constituted health officers are they, scavengers of the fields, that rid them of putrefying animal matter. Instead of burying a dead chicken, dog, cat, or even a large domestic animal, the easy-going Negro lets it lie where it dropped, knowing full well that before it becomes offensive the vultures will have begun to feed upon it. In some of the smaller cities the vultures mingle freely with the loungers about the market-place, gorging upon the refuse thrown about for the only street cleaners in sight. Where robins, woodpeckers, and many species of small song-birds are so lightly regarded as to be killed in shocking quantities and not always for food, the vultures are carefully protected by the Southern people, who, not yet realizing the greater value of insectivorous birds to the farmer, do nevertheless know enough to throw the arm of the law around their feathered scavengers. As if enough services that birds render us had not already been enumerated in this list,- which is merely suggestive and very far indeed from being complete, - the birds that rid our beaches of putrefying rubbish must not be forgotten. While several sea and beach birds share this task, it is to the gulls that we are chiefly indebted. In the wake of garbage scows that put out to deep water from the harbors of the seacoast and Great Lakes where our large cities are situated, and following the ocean liners for the food thrown overboard from the ship's galleys; or resting in the estuaries of the larger rivers where the refuse floats down toward the tide, 


\section{How to Attract the Birds}

flocks of strong-winged gulls may be seen hovering about with an eye intently fastened on every floating speck. Enormous feeders, gulls and terns cleanse the waters as vultures do the land. Millions of these graceful birds that enliven the dullest marine picture have been sacrificed for no more worthy end than to rest entire or in mutilated sections on women's hats! But now that the people begin to understand what birds do for us, a happier day is dawning for them all.

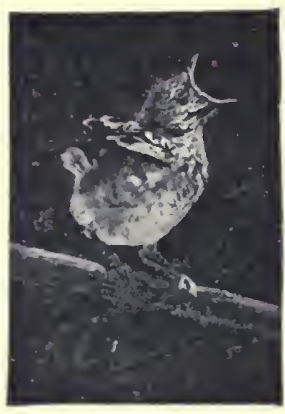


SOME NATURALIZED FOREIGNERS 



\section{CHAPTER IX}

\section{SOME NATURALIZED FOREIGNERS}

From time to time American travelers, wishing to add some bird from the Old World to the steadily decreased ranks of our native species, have brought home with them game birds, songsters and birds presumably useful to the agriculturist, to be released in various parts of the United States. Which are these immigrants living in our midst? How have they fared? Have all proved themselves worthy of naturalization among our feathered citizens?

\section{THE ENGLISH SPARROW}

This was among the first aliens introduced, and I 850 is the earliest known date of his arrival. Then eight pairs were imported by the directors of Brooklyn Institute into their city; and, notwithstanding the fact that the sparrows' first impressions of America were formed in Greenwood Cemetery, where they were set at liberty, they went to housekeeping with great cheerfulness and that marvelous adaptability to new conditions which has made them the most successful colonists among the feathered tribes. It certainly is not because they are meek that they are inheriting the earth.

Not only did individuals continue to import sparrows for the next twenty years, and set them free at 


\section{How to Attract the Birds}

various places from Sandy Hook to Iowa - the San Francisco and other western colonies were not started until i 875 - but corporations took up the task of introducing them into cities where the measuring worms hung from every tree and dropped on every passer-by, only to be crushed under foot until the sidervalks were disgusting. Philadelphia alone imported a thousand sparrows. People benevolently disposed sent them to friends in distant states; they protected, fed, housed and coddled them. Meanwhile the birds, which needed nobody's care, being fit to survive if ever creature was, multiplied enormously, and soon escaped from the cities to towns, and from towns to villages, but always keeping near man, for a parasitical existence ever suits them best. The hardships and dangers of the wild, independent state are carefully avoided by these little tramps. By 1870 they had gained a foothold in twenty states, the District of Columbia, and two Canadian provinces. Now only Alaska, Arizona, Montana, Nevada and New Mexico remain to be invaded. In an old number of the "Transactions of the New York Academy of Sciences" there is an account by a local ornithologist of his visit to Madison Square to see if he could find some English Sparrows which, he had heard, might be seen there. Though written less than forty years ago, it reads like a page of ancient history.

As the "yellow peril" is to human immigration, so is this sparrow to other birds. It is true he banished the measuring caterpillar from our cities and helps destroy the seeds of crab-grass, dandelions, and other noxious weeds on our lawns; but so numerous 


\section{Some Naturalized Foreigners}

are the charges brought against him in the Government's exhaustive report-charges that the bird lover fain would pardon, if in justice he might - that one by one his staunchest old friends are deserting him. In several wheat-growing states where his depredations on the ripened grain cost the farmers many thousands of dollars a year, a price is put upon his head. Reversing the order of Pope's epigram on vice, we first embraced, then pitied and now must endure the English sparrow. Yet had a sparrow exclusion act been suggested when the sparrow craze was at its height, it is doubtful if a single senator who lent his voice to secure the Chinese exclusion act would have given it his support. But our legislators have learned a lesson: the Lacey Act permits no one to bring a foreign bird into this country without permission from the Department of Agriculture.

Not to be confounded with the English housesparrow is the useful and tuneful European treesparrow, which has been successfully acclimated after repeated failures, around St. Louis, Missouri.

\section{AN INFLUX OF SONGSTERS}

A few years before the first English sparrow came across the ocean, Thomas Woodcock, president of the Natural History Society of Brooklyn, imported, for their charm's sake, European goldfinches, linnets, bullfinches, and the skylarks, whose mottled brown coloring suggests more of earth than of heaven. It is known that the last-named species, at least, survived two winters, albeit that over-populated 


\section{How to Attract the Birds}

city of the dead, Greenwood Cemetery, seemed to be the most satisfactory asylum they could find. Possibly the little strangers wished to be personally conducted daily by American angels to sing "at heaven's gate" when "Phœbus 'gins arise." In I 853 more skylarks were liberated in Greenwood, also woodlarks, English blackbirds, and brown thrushes, the

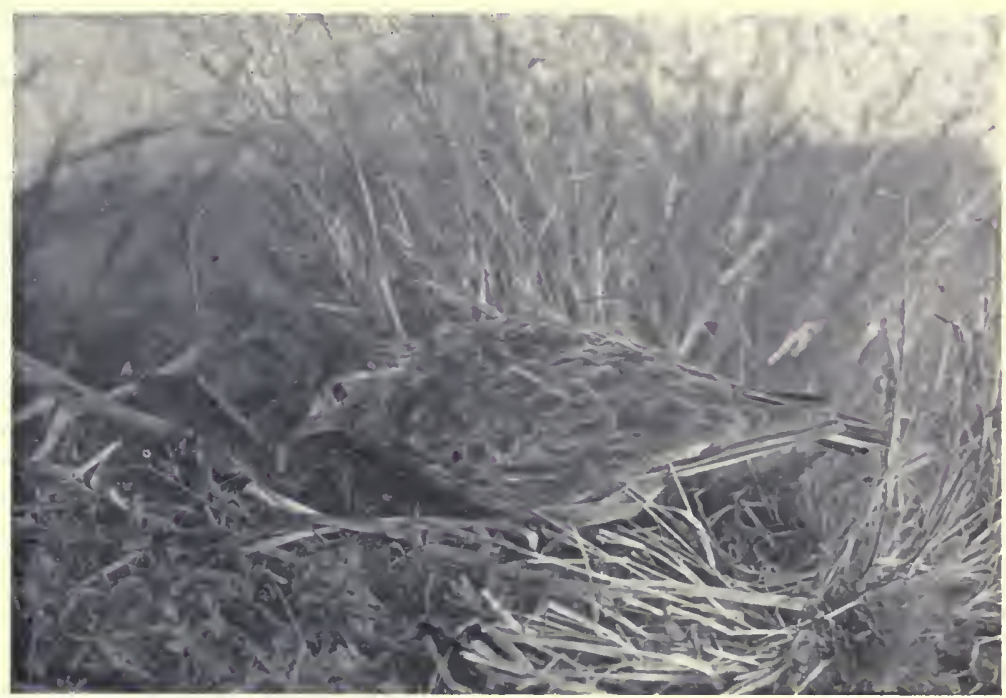

One of the first and most delightful European immigrants to arrive the skylark. (From a mounted specimen)

little robin red-breast - a diminutive edition of our robin - and another lot of goldfinches. Skylarks imported by other enthusiastic lovers of this heavenly minstrel were then soaring and singing above the fields around Wilmington, Delaware, and Washington, D. C., but none survived. So far as is known, the bird has become naturalized only in certain Long Island meadows, not many miles 


\section{Some Naturalized Foreigners}

from Brooklyn, and in the vicinity of Portland, Oregon.

In the early seventies the Acclimatization Society of Cincinnati imported about twenty species of European birds, spending nearly nine thousand dollars on the four thousand individuals that were set at liberty. Unhappily that laudable experiment proved a failure. A similar society at Cambridge, Massa-

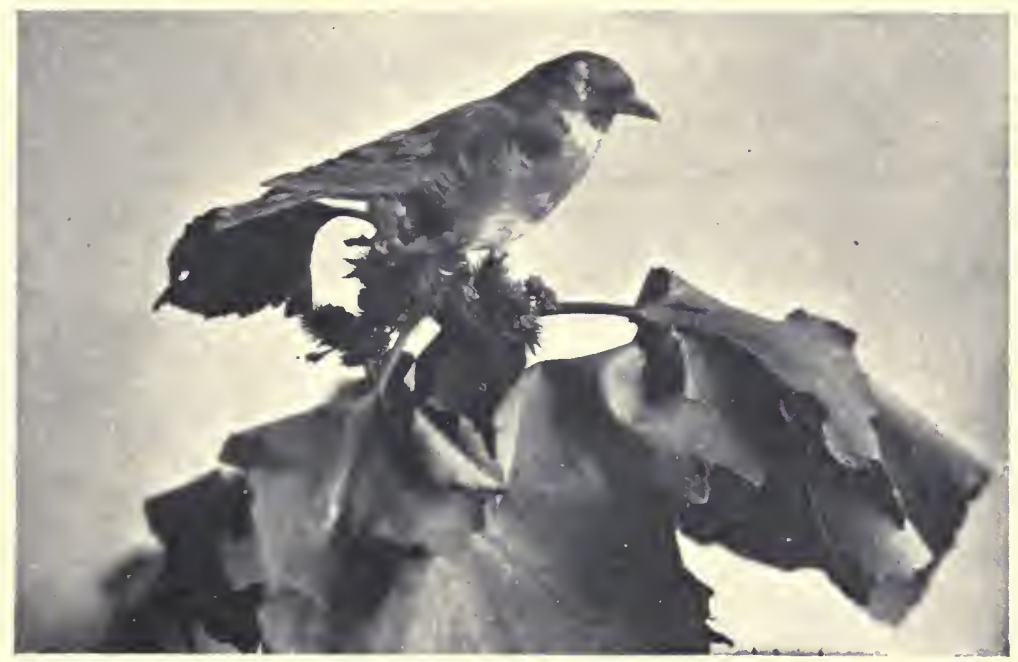

The European goldfinch now naturalized in Massachusetts and New York (Mounted specimen)

chusetts, had better success, at least with its goldfinches, whose descendants are now found in several places in the eastern part of the state. Goldfinches released in Hoboken, New Jersey, in 1878, soon found their way across the Hudson river to Central Park, New York city, where their descendants still flourish. Apparently the charming little black and yellow American goldfinches gave their less amiable 


\section{How to Attract the Birds}

European relatives a cordial welcome, for flocks seen in Bronx Park and at other points around the upper end of Manhattan Island frequently contain both species. The immigrant is a trifle larger than the native, although both are smaller than the sparrow; he has a bright red region around the base of his strong, sharp bill; the top of his head and the sides of his neck are black, as are also his wings and tail; the former is crossed by a yellow band, the latter marked with touches of white; his back is cinnamon brown and the under parts are white, lightly washed with the same shade across the breast. May his tribe increase!

Neither expense nor failure seems to prevent enthusiastic bird lovers from continuing these colonization schemes, at which nature cruelly laughs so often. Three attempts to introduce the starling were made in New York before I89o, when at length success crowned the efforts of Mr. Eugene Schieffelin, who has probably paid the passage of more feathered immigrants to this country than any other American. Like the sparrow, the starling is not afraid to live in cities. It nests on the Strand, London, and early in the spring of 1902 three pairs made their home in the cornice of the building on Union Square, New York, where the publishers of this book have their offices. The clanging of cable-cars in the busy thoroughfare below, the rattle of wagons, street vendors' cries, even the steam drill and the blasting of rocks in the subway, which shook the building to its foundations, did not disturb their domestic peace. Cracked corn, crushed hemp seed, and mockingbird food, which were kept on the fire 
escape outside the publisher's windows, may have had something to do with their perfect content. Passers-by would look up at the sound of their unfamiliar musical whistle - two long-drawn, high, clear notes, the last a trifle higher than the first - and see an unfamiliar black bird, suggesting a grackle, but with a short, square tail, which emphasized the length and point of the wings. Seen at close range at the nesting season, the plumage is glossy black brightly shot with purple, green, and steel-blue iridescence. After the annual molt new feathers come in tipped with buff, which makes the plumage look heavily speckled at first. Gradually it is more lightly sprinkled with dots, as the markings wear off, until the bird is wholly black in time to go a-wooing. Then his bill becomes bright yellow.

With us the starling is a permanent resident. From Staten Island and the opposite New Jersey and Long Island shores up the Hudson thirty miles or more, and along the Sound as far as New Haven, Connecticut, it is slowly extending its range. Noisy broods are reared in tree hollows preferably. Seen in flight, the bird appears triangular, owing to the wide stretch of its long wings and its short tail, whereas the grackle's long steering gear is its most characteristic feature. Sailing for some little distance before alighting, the starling finally settles in large, open spaces and walks over the groundcrow fashion. On the South Downs of England I have watched it familiarly riding on the sheeps' backs, looking for pests imbedded in the fleece, or walking through the fields after the plow, devouring 


\section{How to Attract the Birds}

wholesale quantities of grubs and crawling insects. Both agriculturists and graziers count it their very useful ally, and it is so considered throughout Europe. The worst that can be said of it is that

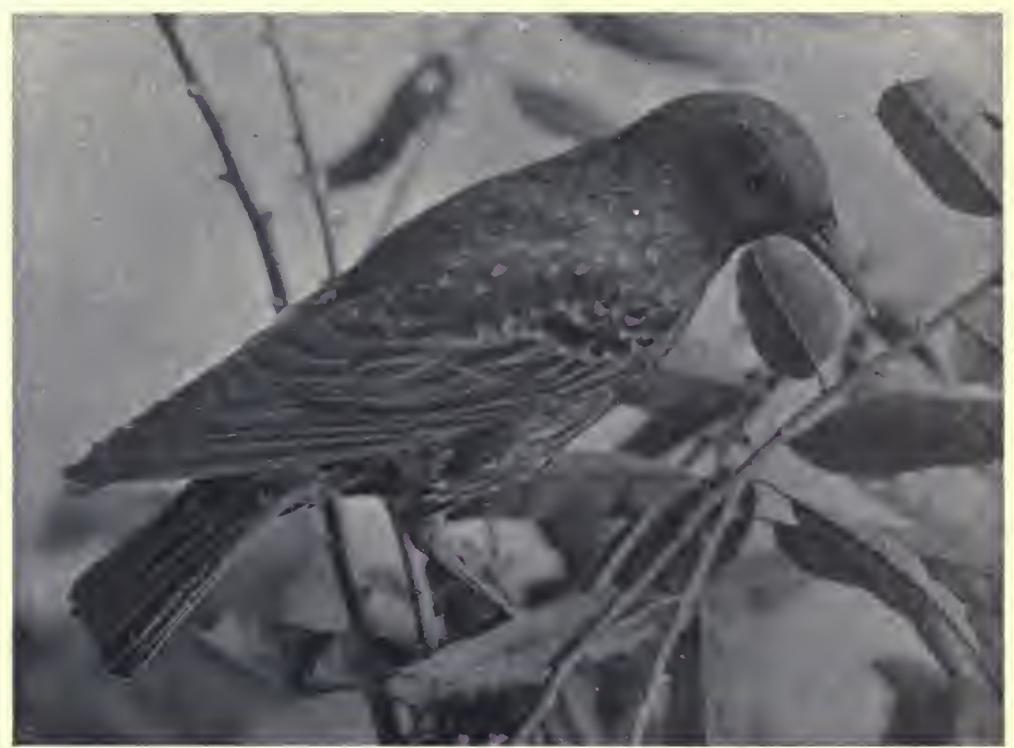

Starling before his speckles have worn off. (Mounted specimen)

it occasionally pilfers small fruits, but never so much as the robin.

With extraordinary precision, great Hocks of starlings, numbering sometimes hundreds of birds, wheel around through the air, close ranks, spread out again, rise and descend, as if the regiment were a single living thing. This is their usual evening performance before settling to roost in their native land. At their present rate of increase, it will not be long before they can engage in similar manæuvers here. 


\section{Some Naturalized Foreigners}

\section{WESTERN COLONIZING AGENTS}

Activity in introducing foreign birds has been by no means confined to the east. Beside the group of men in St. Louis who naturalized the tree-sparrow already referred to, many individuals throughout the western states have encouraged the immigration of birds from Asia, as well as Europe. The first Mongolian and other Asiatic pheasants to reach the United States were sent to Oregon from China in I 88 I by Judge O. N. Denny, formerly consul-general at Shanghai. Most of the birds died on the long voyage, only twelve males and three females reaching. Portland alive. Later, about three dozen ringnecked pheasants were liberated in one place and nineteen at another. Two years after, golden and silver pheasants were placed with some ring-necks on Protection Island, near Port Townsend, Washington. While all four colonies were successful, the hardy, prolific Mongolian pheasant, as might have been expected, increased more rapidly than all the others put together. Within ten years it had overrun western Oregon, and now promises to become a common game bird if sufficiently protected.

"English pheasants," says Mr. T. S. Palmer, of the Biological Survey, "have been imported mainly in the eastern states; some were liberated near Tarrytown, New York, about thirty-five years ago; seventy-eight were turned out on Jekyl Island near Brunswick, Georgia, in 1887 , and these increased to eight hundred and fifty during the following year; others were introduced into New Jersey. Since 1890 there has been widespread interest in these experi- 
ments, and pheasants (mainly Mongolian) have now been introduced into at least twenty-five states, and have increased rapidly through protection laws and the establishment of pheasantries for their propagation." Concerning the other foreign game birds, for whose naturalization many enthusiastic sportsmen have labored in vain, the painful facts are quickly told. The few sand grouse liberated in Oregon promptly disappeared. Of a large importation of Indian black partridges only three lived to reach their destination in Illinois. The black grouse, which has been liberated in Newfoundland, in Vermont and other eastern states, appears to be holding its own. Recently the capercailzie has been introduced in the Adirondacks.

Although several thousand European quail were distributed in New England and the middle states, all disappeared after a year or two. What splendid results the same amount of money and effort expended on our more desirable Bob-White, or the fast disappearing prairie-grouse, or the woodcock, for example, might have accomplished! Ought we not to be just before we are generous?

Thanks to the homesickness of the Dutch and English colonists, who had no sooner cleared the wilderness around their homes than they sent to Europe for trees, shrubs, vines, and plants from the dear old gardens left behind, our native flora was speedily enriched by valuable additions, many of which took kindly to the soil and, escaping from cultivation, became wild. And how many weed seeds stole a passage across the Atlantic with them! Perhaps the colonists longed as greatly to see the 
familiar birds from their old homes, too, but no one risked sending for them until steam shortened the ocean crossing. Within the last few years, a number of bird-loving Germans living in Portland, Oregon, have been doing their utmost to naturalize the songsters of the Fatherland on the Pacific slope. Owing partly to the equable climate of the Puget Sound region making migration unnecessary, their efforts are uncommonly successful. Blackbirds, thrushes, starlings, skylarks, green finches, and goldfinches have been acclimatized, and are increasing. A second attempt to introduce the nightingale and the blackcap was made early in the spring of 1902 , when a large importation reached New York in safety; but, shameful to tell, the majority of them were permitted to die on the way to Oregon for want of water!

\section{A CHASE IN MID-OCEAN}

If some of these feathered travelers from Europe could write the story of their adventures and their impressions of America, what thrilling, hair-breadth escapes might be told, what a stimulating effect the "odious comparisons" might have on our lightlyenforced or non-existing bird laws! Because the birds chiefly concerned in the following tale couldn't write it, unfortunately it necessarily ends at the opening of its most interesting chapter.

In an out-of-the-way corner of London, at the back of a bird fancier's shop, where cockatoos and parrots screamed and swore at one another, dogs yelped and whined while straining at their chains, 
pigeons cooed their tiresome love stories all the day long, and shrill-voiced canaries tried to drown every other noise, some blackbirds and brown thrushes were seen huddled together, silent and disconsolate, in tiny, dirty cages. From the condition of their plumage it was evident that they had been caged many months.

On that bright May morning when an American visitor chanced to enter the bird shop, wild thrushes were tripping lightly and swiftly through the grass on every lawn in England with the same freedom of motion, the same alert grace that characterizes their American cousin, the robin. Sweet, bell-like notes were pealing from the throats of happy thrushes throughout merry England at that glad time of the year. In every English hedge blackbirds piped the richest of sweet songs to nesting mates hidden among the blossoming hawthorns. There are no finer songsters living than these two. The contrast afforded by the miserable, dejected thrush and blackbird prisoners in the shop was too appealingly piteous: every one-there were only twelve pairswas purchased forthwith.

But the American visitor loved her own land too well not to take those birds home with her. Two days later they had started westward across the Atlantic, comfortably housed in large cages, which were placed in a sunny, sheltered corner of the upper deck. Their spirits quickly revived; so did their appetites, which were amazing. A sack of sand, another of crushed hemp, some patent food for softbilled birds, garden snails, and fresh fruit from the table, kept them in perfect health. 


\section{Some Naturalized Foreigners}

No matter how much food was in their cages, they ate only twice a day, in the early morning and late afternoon. One evening when their guardian opened the thrushes' door to refill a drinking cup, suddenly a bird brushed past her face: a thrush had escaped! From stem to stern of that great steamer a lusty German sailor and the bereaved American pursued that little bird. After resting a moment on the moorings of a lifeboat it flew among the rigging, then down on the deck, then up on the captain's bridge, and finally took shelter from the wind and human pursuers under a piece of sail-cloth beyond reach. And the wise captain would not permit the sailor to climb after it then. "If it flies away from the ship," said he, "it is lost forever; it could never overtake us and would soon die. Wait until it goes to sleep ; then the sailor may try again."

Darkness fell; the long, table d'hote dinner of a German liner finally dragged to an end, and news of the supperless, solitary thrush under the sail-cloth was eagerly sought for. "It's too bad," said the officer on the bridge, in his kind German way. "When you were at dinner your little bird was sleeping with one eye open, it seems; he was too quick for that sailor. No; I don't know which way he flew. Maybe he went straight to sea in the dark; maybe he flew toward the stern of the ship. If so, I guess he was drawn by suction down one of those big funnels, and that ends him, sure, if he went down the one that leads to the engine-room. Never mind," he continued, trying to be consoling. "What's the use of bothering about one leetle bird?"

But the guardian, refusing to be comforted, 
sought the seclusion that the cabin granted, and surrendered her imagination to dismal reflections. Poor little solitary waif, beating its wings, so long unused, back and forth above the waves over an unknown sea, engulfed in darkness, straining every muscle to reach the lights on the fast disappearing vessel, only to sink at last from exhaustion into the cruel, cold sea! A sharp knock at the stateroom door startled the occupant. Without waiting for a "Come in," blonde Gustave, the room steward, threw open the door and entered, smiling, with the truant thrush safe in his hand! "It flew down the funnel into the butcher shop," said Gustave, simply. The butcher asked the officer on the bridge if a pet bird had been lost by any of the passengers. The officer said, "Yes; take it to stateroom i $17 . "$

Not a feather had been injured. That particular thrush took an extra long nap the next morning when its companions were feasting on snails, otherwise it appeared none the worse for its reckless adventures. Three days later, when the cage doors were purposely opened on the lawn of their guardian's Long Island home, thrush followed thrush with a glad cry, and blackbirds followed thrushes to the trees and freedom. Now the really interesting part of this story would properly begin. 


\section{N D E X}

The asterisk $\left(^{*}\right)$ before a number indicates the page on which a picture of the bird or its nest may be found.

Auk, The, i io, II I.

Beach birds, 102, 203.

Bittern, American, 102.

Blackbirds, The, 185, 188, 217 .

Blackbird, European, 210, 2 18.

Blackbird, Red-winged, 135 .

Blackcap, European, 2 i 7 .

Bluebird, *6, $7,48,{ }^{*} 79$, I 35, I 45 , I $48,{ }^{*}$ I 58, I 76, I 90 .

Blue Jay. See Jay.

Bobolink, 39, 57, 89, I00, I1 6, I20, I 34, I 36, I 53,188 .

Bob White, 78, 81, I19, I85, I88, 216.

Bullfinch, European, 122, 209.

Bunting, Indigo, 95, $120,{ }^{*} \mathrm{I} 9 \mathrm{I}$.

Bunting, Snow, $146,187,188$.

Buzzard. See Vulture.

Canary, I22, 123.

Canary, Wild. See Yellow Warbler.

Capercailzie, 2 I 6.

Cardinal Grosbeak. See Grosbeak.

Catbird, Io, I 3,54, I 76.

Cedar-bird, or Waxwing. See Waxwing.

Chat, Yellow-breasted, 54.

Cherrybird. See Waxwing.

Chewink, I 39, I 57, I85, I 88 .

Chickadee, 5, I 3, I $6,{ }^{*} 48,{ }^{*} 49,50$, I $19,146,180,190$.

Chicken, Barnyard, 40, 78, 81, 109, I 16,125 .

Cormorant, 76 .
Cowbird, 57, *61, 82, 188 .

Creeper, Brown, I3, I8o.

Crossbill, American Red, I $+6,1+9$.

Crossbill, ${ }^{*}$ White-winged, I 49 .

Crow, American, 72, 87, 89, I09, I30, ${ }^{*}{ }_{44}, 151,157,170,185$.

Cuckoos, The, II, +1, 105, 176, 177, I 78 .

Cuckoo, Black-billed, 178 .

Cuckoo, European, 57.

Cuckoo, Yellow-billed, I30, I 78 .

Dove, Mourning, $4 \mathrm{I},{ }^{*}+3,53,{ }^{*} 74$, I 88 .

Ducks, The, 3, 40, 78, 80, I08, I43, I 8, I 54 .

Duck, Chinese Mandarin, $5 \mathrm{I}$.

Duck, Wood, 48, 5 I .

Eagle, 82, I09.

Egret, 4I .

Finches, The, 12, I 86, 188.

Finch, Green, European, 217.

Finch, Purple, 75, 97.

Flicker, I1, I6, ${ }^{*} 47,75,107,108$, * I 29, I 30, I 80, 185 .

Flycatchers, The, I05, I 47 , I 5 , 174 .

Flycatcher, Crested, 16, 54 .

Goldfinch, American, (Thistle-bird), $6,12,53,100,187,211$.

Goldfinch, European, 121 , 209, 210 , *2II, 2 I 7. 


\section{Ind e $x$}

Goose, Wild, I09, I33, I5I, I58.

Goshawk, I99.

Grackle, Bronzed, ${ }^{*} 5,7,130,188$, 2 I 3 .

Grosbeak, Cardinal, 10, ${ }^{*} 98,99,120$, I 34 .

Grosbeak, Rose-breasted, 99, ${ }^{*}{ }_{37}$, I 87.

Ground Robin. See Chewink.

Grouse, The, I 85 .

Grouse, Black, 216.

Grouse, Canada, 127.

Grouse, Prairie, I26, 2 I6.

Grouse, Richardson's, * 107 .

Grouse, Ruffed, 42, *78, * 96, I05, I26, I 88, I 99.

Grouse, Sand, 216.

Gulls, The, I02, I $46,203$.

Gull, American Herring, 85, 1 +6, *202.

Hawks, The, 3, 72, 77, 95, 108, Io9, I $33,170,173,196$.

Hawk, Cooper's, I99.

Hawk, Duck, I99.

Hawk, Fish. See Osprey.

Hawk, Red-shouldered, ${ }^{*}$ I 7 .

Hawk, Sharp-shinned, 199.

Herons, The, 41, 79.

Heron, Snowy, 97.

High-hole. See Flicker.

Humming-bird, Ruby-throated, 12, ${ }^{*} 21-36,54,75,{ }^{*} 76,88$, го9, 152.

Indigo Bunting. See Bunting.

Jay, Blue, I3, 72, I30, ${ }^{*} 133$.

Jay, Florida, 74 .

Junco, $146,158,187$.

Kildeer, I19.

Kingbird, 87, 106, 109, 174 .

Kingfisher, Belted, $t^{2},{ }^{*}+5,79,88$, I 3 O, * I 3 I.

Kinglet, Golden-Crowned, I 4 , I 8o.

Kinglet, Ruby-Crowned, I 46 , I so.
Lark. See Skylark.

Lark, Horned, is8.

Lark, Meadow. See Meadow-lark.

Lark, Wood, 2 10.

Linnet, 209.

Longspur, I 46,187 .

Loon, Common, ro8.

Martin, Purple, I6, I $47,173,{ }^{*} 89$.

Meadow-lark, 57, 139, 183, I88.

Mocking-bird, I3, I20, I22, *123, I 33,176 .

Night-hawk, $+2,102,{ }^{*} \mathrm{IO}_{3}, \mathrm{I}_{29}, \mathrm{I}+8$, I 74 .

Nightingale, European, 217.

Nuthatches, The, I 3, I $6,50, * 88$, I 4 , i 80, I9o.

Nuthatch, Red-Breasted, 65.

Nuthatch, WWhite-Breasted, ${ }^{*} 65$.

Orioles, The, 176, I 78 .

Oriole, Baltimore, Iо, I3, 53, 57, 87 , 93, 95, 99, * ${ }_{117}$, I $_{7} 8$, I $_{79}, 1_{95}$.

Oriole, Orchard, Io, 195 .

Osprey, 77.

Ostrich, 79, 80, 108.

Ovenbird, 54, 89, 185 .

Owls, The, $16,48,72,77,108,133$, I $70,173,196$.

Owl, Horned, 77, * 199 .

Owl, Screech, * 155 .

Owl, Snowy, roo, I+9.

Paroquet, Carolina, 98 .

Partridge, Indian Black, 2 r6.

Peabody Bird. See White-throated Sparrow.

Pelican, Brown, 76.

Perree, Wood, I19, 174 .

Phalarope, 8o.

Pheasant, English, 215.

Pheasant, Mongolian, 215.

Pheasant, Ring-necked, 2 I 5.

Pheasant, Silver, 2:5.

Phobe, 7, 53, 85, *86, I19, 154, 174 . 


\section{In d e $x$}

Pigeon, Wild, 77, I 10, II , I 43 .

Plover, The, $78,80, I_{4} 8,{ }_{1} 85$.

Plover, Kildeer, Ir 9 .

Plover, Ring-necked, I 53.

Ptarmigan, roo, * ${ }_{\text {IOI. }}$.

Quail. See Bob White.

Quail, European, 2 I6.

Redpoll, $146,{ }^{*}+7,187$.

Redstart, 96.

Reedbird. See Bobolink.

Robin, American, 7, 10, 13, 39, ${ }^{*}+0,53,67,{ }^{*} 68,70,79,96$, 1 24 , I $32,145,151,157,176,185,203$, 218.

Robin, Red-breast, European, 2 ro.

Sandpiper, 153 .

Sapsucker, The, I6, I29, I80.

Shrike, Northern, $1+6$.

Siskin, 187 .

Skylark, European, I60, 209, *210, 217.

Snipe, 78, 148 .

Snowbird. See Junco.

Snowflake. See Snow Bunting.

Sparrows, The, 87, 97, 105, 139, 144, $176,185,186,210$.

Sparrow, Canada. See White-throated Sparrow.

Sparrow, Chipping, ${ }^{*} 53,124,187$.

Sparrow, English, 8, 87, 97, I I I, I22, I 57, $170,187,207$.

Sparrow, Field, r34.

Sparrow, Hair. See Chipping Sparrow.

Sparrow, Song, 39, * +1, I20, I 31 , I 35,187 .

Sparrow, Tree, 188, 209, 215.

Sparrow, Vesper, I07, I34.

Sparrow, White-Throated, I20, 187.

Starling, European, The, 2r2, *2r . 217 .

Swallows, The, $46,51,157,173$.

Swallow, Bank, $42,{ }^{*}+6$.
Swallow, Barn, *52, 190.

Swallow, Chimney. See Swift.

Swallow, Tree, +8 .

Swift, Chimney, ${ }^{*} 50,51,108,1+3$, I 73, 190.

Tailor-bird, 52.

Tanager, Scarlet, Io, 87, 95, 99, I 76 .

Terns, The, $+2,102,105$.

Terns, Sooty, I +9 .

Thistle-bird. See American Goldfinch.

Thrasher, Brown, 176, 185, 210 , 218.

Thrushes, The, I0, I3, 58, I34, 157 , I 76.

Thrush, Brown, European, 217.

Thrush, Gold-crow ned, 54 .

Thrush, Hermit, I20, 133.

Thrush, Wood, 13, I34, 145 .

Titmouse, Tufted, 13, I6, 50, 190.

Turkey, Wild, 8I.

Vireos, The, 57, 79, I05, 174 .

Vireo, Red-eyed, г 20.

Vireo, White-eyed, ${ }^{*} 72$.

Vultures, The, ${ }^{*}$ 98, 200.

Vulture, Turkey, 76, ro9.

Warblers, The, I $5,57,144,174$, 177.

Warbler, Blackburnian, 96 .

Warbler, Ground, 185 .

Warbler, Parula, 54 .

Warbler, Redstart, 96 .

Warbler, Yellow, $57,{ }^{*} 60,{ }^{*} 6 \mathrm{r}$.

Waxwing, Cedar. Frontispiece. ${ }^{*}$, 6 , 10, II, I $48,159,{ }^{*} 193$.

Whip-poor-will, ${ }^{*} 94,102,174$.

Woodcock, 77, I05, *I10, I85, 2 I 6.

Woodpeckers, The, I $_{3}, 48,79,96$, 129, 179, 203.

Woodpecker, Downy, 16, 82, ${ }^{*} 8_{3}$, I 30, I $80, *$ I $8 \mathrm{I}$.

Woodpecker, Hairy, 16, I30, I80. 


\section{In d e $\mathbf{x}$}

Woodpecker, Red-headed, I6, I30, I 80.

Woodpecker, Yellow-winged. See Flicker.

Wrens, The, 176, 190.

Wren, Carolina, i36.
Wren, House, $7,16,48,{ }^{*} 51,58,89$, I I 5, I 34, * I 90.

Wren, Marsh, 54, * 55 .

Wren, Winter, 146 .

Yellow-throat, Maryland, 89, I36. 






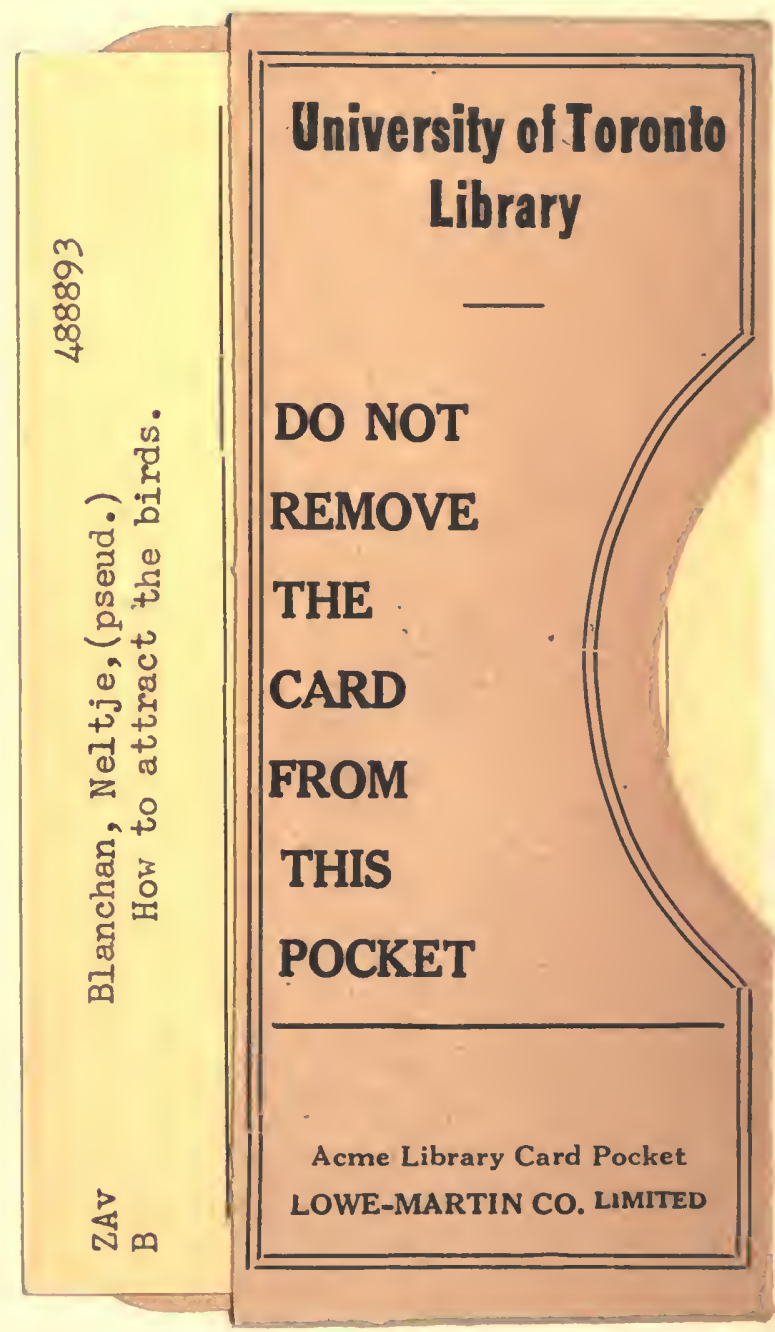


